\title{
The muPETROL Expert System for Classifying World Sedimentary Basins
}

\section{U.S. GEOLOGICAL SURVEY BULLETIN 1810}





\title{
The muPETROL Expert System for Classifying World Sedimentary Basins
}

\author{
By BETTY M. MILLER
}

A microcomputer-based expert system with computer models for classifying world sedimentary basins as an aid to assessing petroleum resources 


\title{
DEPARTMENT OF THE INTERIOR \\ DONALD PAUL HODEL, Secretary
}

\author{
U.S. GEOLOGICAL SURVEY \\ Dallas L. Peck, Director
}

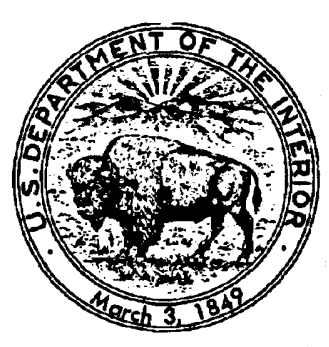

UNITED STATES GOVERNMENT PRINTING OFFICE: 1987

For sale by the Books and Open-File Reports Section, U.S. Geological Survey, Federal Center,

Box 25425, Denver, CO 80225 


\section{CONTENTS}

Abstract 1

Introduction 1

Acknowledgments 2

Expert systems and knowledge acquisition 2

World basin classifications 3

Basin classification systems 3

Klemme's basin classification system 3

Building basin models 3

Application of the model 5

New developments 6

Conclusions 6

Selected references 7

Appendixes 9

A. Sedimentary basin models using the Klemme world basin classification scheme for the muPETROL expert system 11

B. Header file for the muPETROL expert system 12

C-1. Inference net and listing for Introduction and Tutorial model 13

C-2. Transcript of a trial run of Option 1-An Introduction and Tutorial model 24

D. Inference net and listing for Class I-Craton Interior Basins (model 1) 29

E. Inference net and listing for Class IIA-Craton Margin Composite Basins (model 2) 35

F. Inference net and listing for Class IIB-Craton-Accreted Margin Complex Basins (model 3) $\mathbf{4 0}$

G. Inference net and listing for Class IIC-Crustal Collision ZoneConvergent Plate Margin Basins (model 4) 45

H. Inference net and listing for Class IIIA-Craton and Accreted Zone Rift Basins (model 5) 55

I. Inference net and listing for Class IIIB-Rifted Convergent Margin Basins (model 6) 60

J. Inference net and listing for Class IIIC-Rifted Passive Margin Basins (model 7) 69

K. Inference net and listing for Class IV-Delta Basins-Tertiary to Recent (model 8) 75

L. Inference net and listing for Class V-Forearc Basins (model 9) 82

\section{FIGURES}

1. Diagram showing objectives of an integrated system for applying the muPETROL expert system to the assessment of undiscovered petroleum resources 2

2. Inference net showing how the inference rules of the form "IF E (evidence) THEN (to some degree) H (hypothesis)" constitute the primary structure for encoding the geologic knowledge about basin class models 4

\section{TABLE}

1. Klemme basin classification and muPETROL basin model identification 4 


\section{The muPETROL Expert System for Classifying World Sedimentary Basins}

\author{
By Betty M. Miller
}

Abstract

mUPETROL, an operational prototype expert system, patterned after muPROSPECTOR, provides the means for classifying sedimentary basins of the world as a first step in developing an integrated expert systems approach to estimating undiscovered worldwide petroleum resources. The basin classification is based on nine sedimentary basin models using H.D. Klemme's recognition criteria for a world sedimentary basin classification system. Each model is defined by a rule-based system and embodies the geologic concepts of plate tectonics modified by regional tectonics and lithologic and depositional sequences.

The system of rule-based models is used to evaluate the likelihood of one hydrocarbon occurrence or more in a basin on the basis of the geologic characteristics that categorize that basin. These characteristics are also matched against those of known basins in a data base containing nearly 800 world basins classified according to both the Klemme system and the system of A.W. Bally and S. Snelson.

This report discusses the procedures for (1) acquiring the geologic knowledge base (knowledge acquisition) directly from basin experts, published references, and data bases essential for classifying the sedimentary basins of the world and (2) building the basin models for an expert system. Such a system will serve as the first phase in an integrated program leading to a detailed sedimentary basin analysis for the purpose of assessing the undiscovered petroleum resources in the world's basins.

The mUPETROL expert system is operational. It can be used for regional basin analysis consultation and for classifying the world's sedimentary basins on the basis of Klemme's classification scheme.

\section{INTRODUCTION}

A prototype expert system, called muPETROL, has been developed to aid in the assessment of energy resources in the world's sedimentary basins (Miller, 1986a). The first phase of this system consists of nine basin models and an Introduction and Tutorial model. These models are based on criteria developed by Klemme $(1975,1983)$ in his world basin classification system, which differentiates nine major basin classes by their regional geologic frameworks and tectonic settings relative to petroleum occurrences.

mUPETROL is a microcomputer-based expert system, constructed on an IBM-PC-XT by using muLISP ${ }^{1}$ and designed ultimately to evaluate the favorability for petroleum resources within a given sedimentary basin. The basin models are encoded in a form compatible with the muPROSPECTOR system (McCammon and others, 1984), which is patterned after the SRI PROSPECTOR program (Duda and others, 1981; Reboh, 1981). The basin classification models in the muPETROL system are the first in a series of computer models being developed to analyze sedimentary basins. Detailed basin analyses are to follow in the development of this system and will be followed in turn by the development of methods for estimating the remaining undiscovered petroleum resources.

muPETROL's ultimate objective is the construction of an integrated system that will provide a complete sequence of geologic models. These models will document information from the earliest phase of geologic assumptions and interpretations used in analyzing basins, through the critical steps of selecting the resource appraisal method or methods to be applied for the assessment, to the final quantitative assessments of the amount of undiscovered petroleum resources within a basin or smaller geographic area. The resource estimates will be expressed in the form of probability distributions (Miller and others, 1975; Miller, 1979, 1986b). A flow diagram illustrating the general principles for the muPETROL system is shown in figure 1.

The short-term objectives of this investigation are to explore the feasibility of applying the concepts of Artificial Intelligence and knowledge acquisition techniques to the design and construction of a prototype global classification system for sedimentary basins relative

\footnotetext{
${ }^{1}$ The use of trade names in this report is for descriptive purposes only and does not constitute endorsement by the U.S. Geological Survey. muLISP is a general-purpose LISP programming system for microcomputers. LISP is an acronym for list processing language, a popular programming language used in Artificial Intelligence.
} 


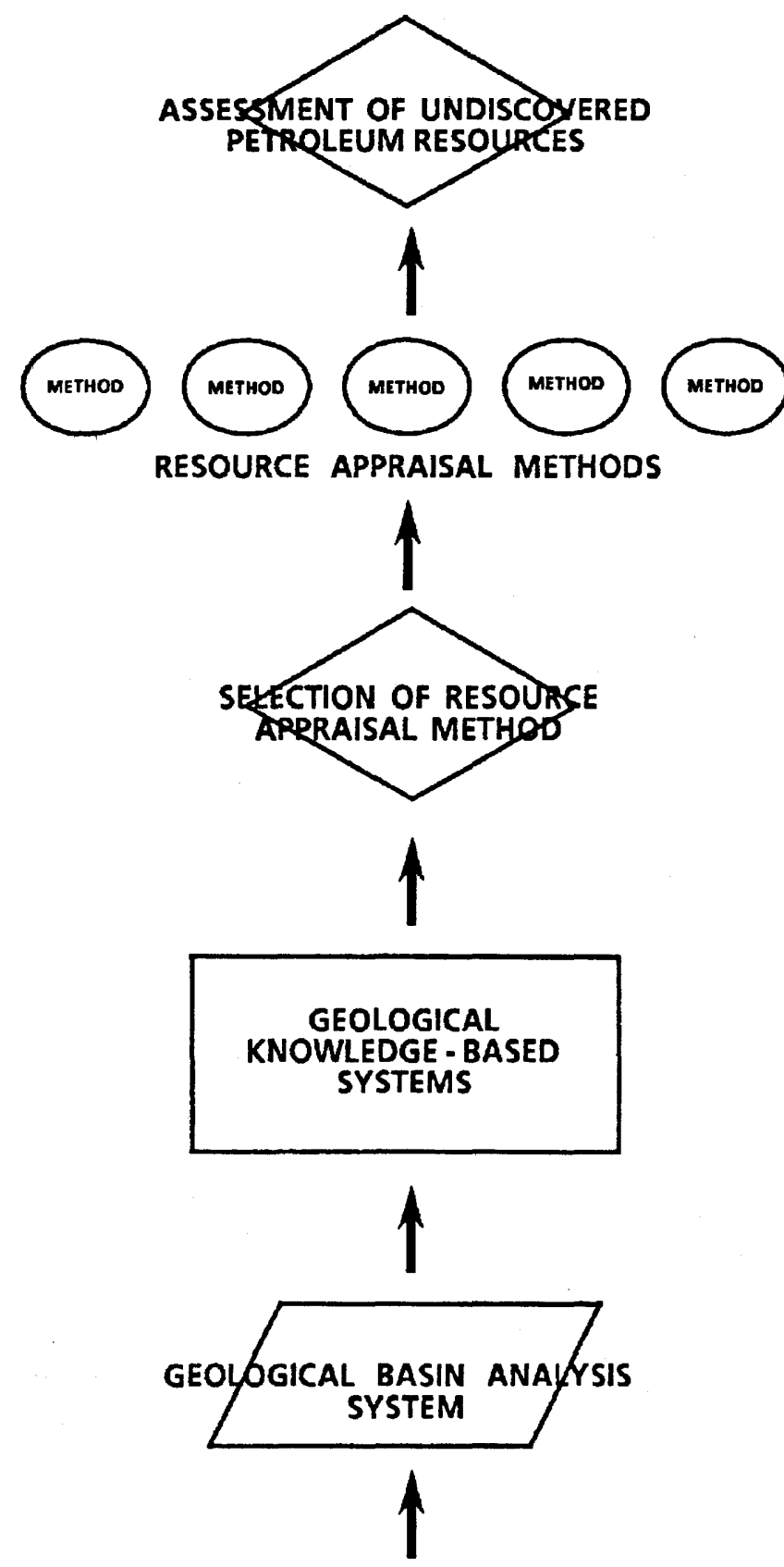

BASIN CLASSIFICATION SYSTEM

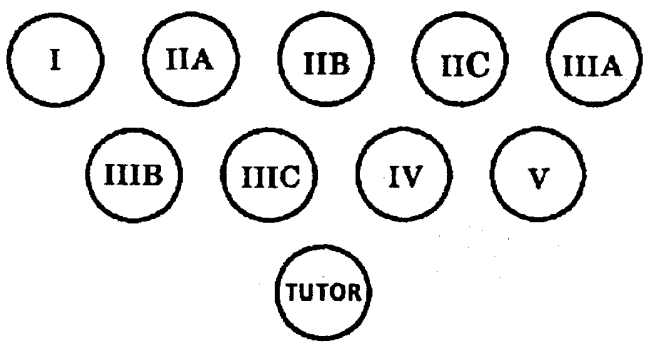

Figure 1. Objectives of an integrated system for applying the mUPETROL expert system to the assessment of undiscovered petroleum resources. to the occurrence of petroleum resources. Preliminary results of the first phase of this study are documented in this report.

\section{Acknowledgments}

The author thanks H. Douglas Klemme, President of Geo Basins Limited, Bondville, Vt., for his interest, contributions, and exchange of ideas on his world sedimentary basin classification system. Thanks are also extended to Richard B. McCammon of the U.S. Geological Survey for his assistance with the PROSPECTOR and muPROSPECTOR computer programs.

\section{EXPERT SYSTEMS AND KNOWLEDGE ACQUISITION}

Although expert systems are relatively new, they are rapidly moving to the forefront of Artificial Intelligence technology. The use of such systems in scientific and commercial enterprises is growing, primarily because Artificial Intelligence technology is becoming better understood, and its application is considered feasible in many areas. An expert system is, basically, a computer program that embodies the knowledge of one or more experts in a particular field and offers this expertise to the user of the system to make useful inferences. In the mUPETROL system, at its present stage of development, such inferences aid in analyzing and classifying a particular sedimentary basin on the basis of rules using Klemme's criteria for sedimentary basin classification.

Expert systems are characterized by an intense focus on knowledge about a subject and the acquisition of that knowledge. The acquisition of knowledge and its representation as a model transfer the problem-solving ability of the expert to a set of rules within a computer program. The principal sources of knowledge acquisition for expert systems include human experts, textbooks, data and knowledge bases, and the "knowledge engineer's" own experiences relative to the particular area of study (Buchanan and others, 1983). This report focuses primarily on (1) acquiring geologic knowledge about sedimentary basins from experts, published references, and data bases and (2) generating the nine basin models and the Introduction and Tutorial model for the muPETROL expert system.

More detailed information on the processes of knowledge acquisition and the construction of expert systems is provided by a growing selection of publications on expert systems (Hayes-Roth and others, 1983; Waterman and Hayes-Roth, 1983; Winston and Prendergast, 1984; Harmon and King, 1985; Andriole, 1985; Waterman, 1986). 
WORLD BASIN CLASSIFICATIONS

\section{Basin Classification Systems}

Many systems for classifying sedimentary basins have been proposed over the years, ranging from those of a more academic nature (for example, Bally and Snelson's (1980) classification, based solely on the concepts of plate tectonics) to those of the more pragmatic petroleum geologists, whose main objective is to assist in forecasting the occurrence and magnitude of a basin's petroleum resources (Klemme 1975, 1983). The following published basin classifications represent a variety of classification schemes: Weeks (1952), Knebel and Rodriguez-Eraso (1956), Brod and Vysotskiy (1965), Uspenskaya and Tabasaranski (1966), Uspenskaya and Tauson (1972), Halbouty and others (1970a, b), Perrodon (1971, 1977), Klemme (1971a, b, c, d, 1975, 1977, 1980, 1983), North (1971, 1979), McCrossan and Porter (1973), Bally (1975), Huff (1978, 1980), Bally and Snelson (1980), Bois and others (1982), and Kingston and others (1983a, b, 1985a, b, c).

The objectives of these classifications are wide ranging. Bally and Snelson (1980, p. 10) stated that the intent of their classification, which is based entirely on plate tectonic concepts, “.... is through classification to fit seemingly 'unique' observations into an ordered hierarchy which, at the very least, provides a means of structuring our ignorance." Klemme's $(1975,1983)$ studies are based partly on plate tectonics but have been modified by basin tectonics and lithologic and depositional seqtences, the aim being to relate the occurrence of giant fields and field-size distributions to basin characteristics for the purpose of providing basin analogs to forecast their petroleum potential. The work of Bois and others (1982) and Kingston and others (1983a, b, 1985a, b, c) is based partly on plate tectonics and basin-forming and basinmodifying tectonic cycles and partly on depositional stages and is intended to analyze and identify each basin's petroleum zones or hydrocarbon plays for the purpose of assessing its petroleum resource potential.

Considering the conclusions of Bally and Snelson $(1980$, p. 71$)$ as possibly the "worst-case scenario" (that is, "the classification of basins does little to improve our hydrocarbon volume forecasting ability") and assuming that classifying sedimentary basins is only the first step toward a systematic approach to the assessment of petroleum resources, I have written this report to document the initial stages in the development of a system using a world basin classification scheme based on a global tectonic framework. The purposes of using this world basin classification system include (1) promotion of a system that can be used to compare all the world's basins within a single conceptual framework; (2) analysis of the distri- bution of petroleum resources within that conceptual framework; (3) division of complex basins into their component parts for analysis; (4) comparison and evaluation of favorable petroleum zones or hydrocarbon plays within and between basins and basin types; (5) analysis of those geologic characteristics significant to the occurrence of petroleum resources; and (6) prediction by means of evaluating the favorability of petroleum occurrence in little-known or frontier basins on the basis of analogs within known or similar basin classes. Systems such as muPETROL can also be used as tutorial systems or computer teaching tools for the analysis of regional basin tectonics, basin classification techniques, and the use of expert systems as research application tools.

\section{Klemme's Basin Classification System}

Klemme's world sedimentary basin classification scheme was used in designing the basin models in the muPETROL system for several reasons. Foremost was Klemme's objective of providing basin analogs to forecast petroleum potential. Klemme's system provides for a global tectonic basin classification. Moreover, it can be adapted to provide a tutorial system for teaching basic plate and regional basin tectonics and techniques for classifying sedimentary basins. Finally, as an expert in this field, Klemme has a personal interest in the design of petroliferous sedimentary basin models.

Klemme's world basin classification system and related petroleum studies have been discussed extensively by Halbouty and others $(1970 \mathrm{a}, \mathrm{b})$, Klemme (1971a, b, c, d, 1975, 1977, 1980, 1983), McCrossan and Porter (1973), and St. John and others (1984).

I have used the 1984 version of Klemme's basin classification scheme for identifying the geologic criteria and designing the rule-based logic for the basin models and for the analog listing of nearly 800 world sedimentary basins (St. John and others, 1984). Table 1 shows the petroleum basin classes in the Klemme classification, the crustal tectonic location for each basin class, and the basin model number used in muPETROL.

\section{BUILDING BASIN MODELS}

Designing a new basin model is a creative and challenging activity involving the synthesis into a precise computer language of the scientific understanding about a specific type of sedimentary basin. The development of a model for each basin class requires positive feedback by matching it against known sedimentary basins as analogs (Duda and others, 1978, 1981).

The critical constituents or rules for the basin models in muPETROL, which relate geologic observations or evidence of the hypotheses, are represented by logic 
Table 1. Klemme basin classification and muPETROL basin model identification

[Modified from St. John and others (1984, table 2, p. 5)]

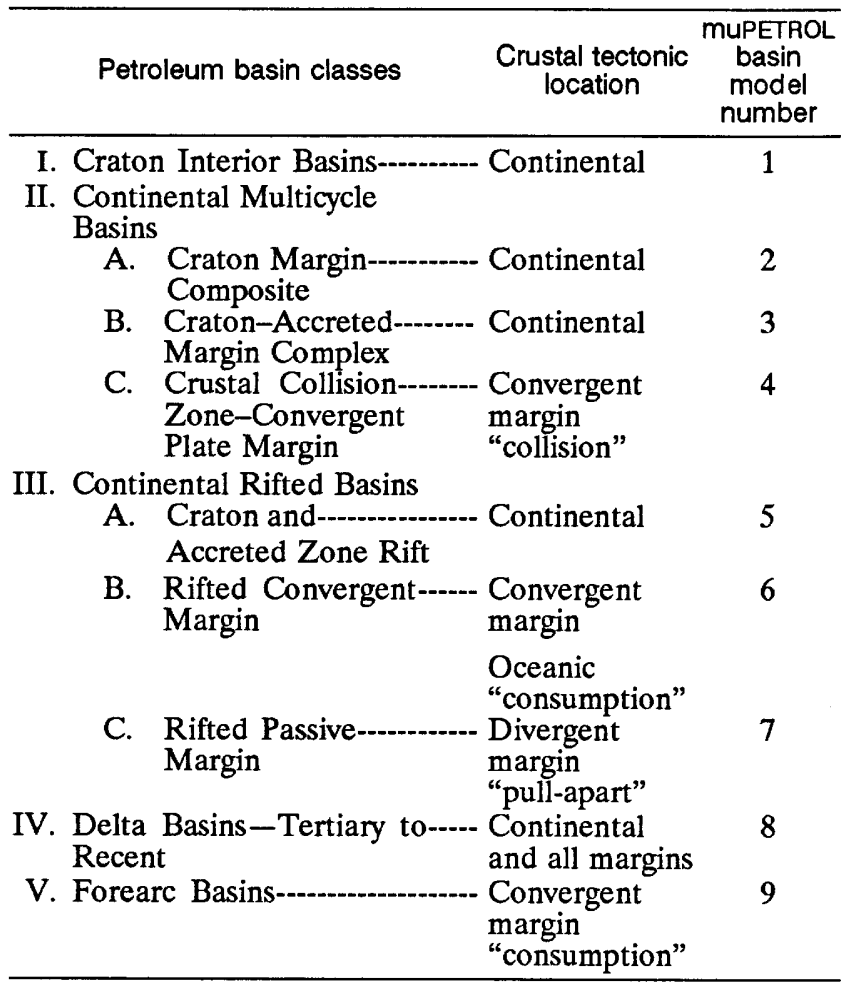

diagrams known as inference nets. These networks illustrate the logic used to infer the likelihood of occurrence of a particular basin type on the basis of the combined presence or absence of a set of geologic attributes. Such a network is embodied in a particular genetic-geologic model. The network is equivalent to a collection of plausible rules. In general, a rule has the form: IF $<$ antecedent $>$ THEN < rule-strength $><$ rulestrength $><$ consequent $>$ or IF E THEN (to some degree) $H$. Such a rule is interpreted to mean "The observed evidence $\mathrm{E}$ suggests (to some degree) the hypothesis $\mathrm{H}$," as illustrated in figure 2 (Waterman and Hayes-Roth, 1983; Reboh, 1981). A probability can be associated with each observation or hypothesis. An hypothesis (right-hand side) is affected by an observation (left-hand side). ${ }^{2}$

Inference rules of the form <evidence $>\longrightarrow$ $<$ hypothesis $>$ constitute the primary structure for encod-

\footnotetext{
${ }^{2}$ In the PROSPECTOR system rule strengths, certainty factors and prior probabilities for each piece of evidence or hypothesis can be incorporated into the system. However, muPETROL (patterned after muPROSPECTOR) does not have this capability, and the user simply answers "yes," "no," "I don't know," and so on to the questions. Future developments for muPETROL are to include the use of rule strengths and certainty factors and the ability to handle numerical input by means of a different expert systems shell known as KESII (Knowledge Engineering System II).
}

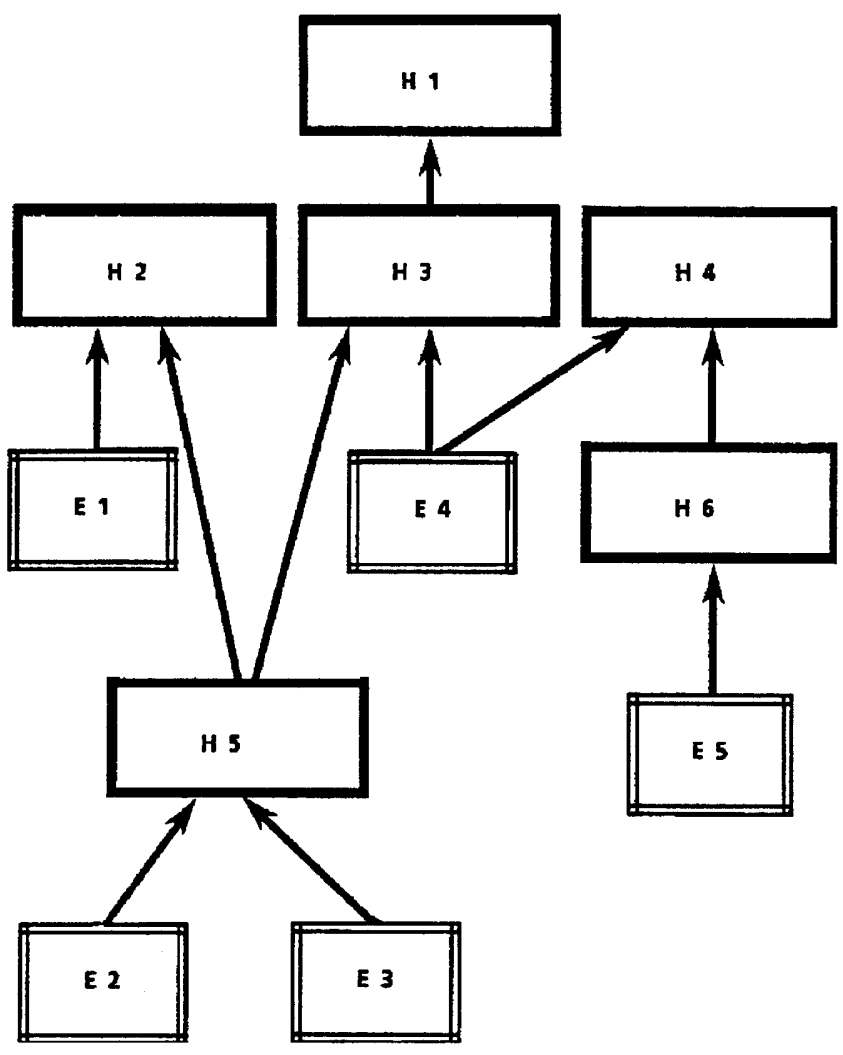

Figure 2. Inference net showing how the inference rules of the form "IF E (evidence) THEN (to some degree) H (hypothesis)" constitute the primary structure for encoding the geologic knowledge about the basin class models. Simpler pieces of evidence may be combined to form more complex pieces of evidence and, subsequently, to form hypotheses.

ing geologic knowledge about the basin models. In the inference network for the basin models, different pieces of geologic evidence can also be combined logically to form a single compound piece of evidence. The simpler elements of evidence can be combined by means of the primitive operations of the logic combinations AND, OR, and NOT. The rules are interconnected in various ways by means of either forward or backward "chains" or "chaining," where the hypothesis for one rule is the evidence for another or where the same piece of evidence has bearing on several different hypotheses. The illustration in appendix $\mathbf{J}$ shows the inference network encoding a muPETROL basin model for the Klemme basin Class IIIC (model 7) using 15 rules and 32 nodes with identified space codes. muPETROL's present knowledge base now contains nine basin models that have more than 160 rules and 300 nodes with identified space codes and an Introduction and Tutorial model that has over 45 rules and 60 nodes, for a total of over 200 rules and nearly 400 nodes. Appendix A lists the muPETROL basin models.

In the preparation of a basin model, the general structural form of the inference network is constructed as follows: 
1. Establish the nature of the crustal basin basement (that is, continental crust (craton interior or accreted marginal zones) or oceanic crust).

2. Determine the tectonic location relative to past plate movement (plate tectonics) involved in the formation of the basin (that is, divergent, convergent, or the presence of both types of tectonics over time).

3. Determine the geographic location of the regional or basin area relative to global geography (that is, North American interior craton, Atlantic oceanic margin, and so on).

4. Describe the structural evolution of the basin by identifying the characteristics of the basin-modifying or basin-forming tectonics (that is, structural movements, types of faulting, and so on).

5. Describe the stratigraphic evolution of the basin by characterizing the depositional cycles relative to the tectonic periods. These basin cycles can range from simple, single-cycle basins to complex, multicycle basins (that is, simple, single-cycle, craton interior basins to multicycle, craton-accreted margin basins).

The geologic conditions for each basin model are described in the present tense in the question-answer format for present-day observations made by the geologist. The interpretive genetic, tectonic, and depositional concepts expressed in the format are stated in the past tense if they describe geologic events that have taken place throughout the history of the basin. Wherever possible, the statements (in the question-answer format) within each of the above-listed five stages are placed in chronological order, from the oldest geologic event or process to the youngest.

The appendixes present the listings of the computer files for each of the nine basin models and the Introduction and Tutorial model, along with a diagrammatic representation of each model's inference net. These listings are programmed for muLISP (Microsoft, 1986). The reader inclined to "do it yourself" is referred to McCammon's (1986) report (appendix C for the muPROSPECTOR program listing; appendix B for the Backus-Naur form description of the formal language for external representation of muPROSPECTOR models).

\section{APPLICATION OF THE MODEL}

A basin evaluation using muPETROL consists of a probabilistic estimate of the likelihood of occurrence of a given basin type coupled with a documentation of the geologic reasons (geologic attributes) on which the evaluation is based. Each evaluation takes into account favorable and unfavorable evidence. Such evidence is useful in determining the essential missing information or in reas- sessing uncertain data in either frontier or partially explored areas.

Once constructed, a geologic basin model can be used in various ways to evaluate the favorability for a basin match and as a preliminary geologic evaluation leading to a more detailed basin analysis for assessing hydrocarbon occurrences. In the simplest example, a model can be used to evaluate a region or a basin area by subjectively deciding how well the region or basin matches the characteristics of any one of the nine Klemme basin classes. A geologist can thus use each basin model as a tool for reviewing and comparing the geology of a basin class with that of a given basin, determining the classification of a given basin, and assessing the favorability of a given sedimentary basin for petroleum occurrence. These initial steps are usually taken in a basin analysis, regardless of the type of basin classification system used, in preparation for applying most of the methodologies commonly employed in estimating the undiscovered energy resources of a sedimentary basin.

To expedite the early phases in these procedures, I have devised a system of questions to elicit a user's knowledge of the geologic base and of the tectonic and depositional concepts relative to each basin model. The answers to these questions provide a means of comparing test basins with a given control basin or an analogous basin. The questions are asked in a fairly uniform manner, so that they can be answered in the positive (yes), in the negative (no), or as "don't know" (D). Questions that need to be answered by specifying some numerical quantity cannot be processed by using existing software in the muPROSPECTOR system and must be phrased to conform with the above scheme. In addition to supplying answers, a user can request information at any time by the following commands:

?-Print a rephrased version of the question or an explanation of the question

A-Access available data base to assist in answering the question

At any time during the consultation, the geologist can ask muPETROL to summarize and make an evaluation based on the current information that the geologist has provided by the following command:

$\mathrm{S}-$ Summarize its conclusions on the basis of information provided

The user can trace muPETROL's intermediate conclusions by typing " $\mathrm{T}$." This command allows the user to monitor the progress of the consultation. The user stops the trace by typing "U."

(T)RACE-Trace the progress of the consultation

(U)NTRACE-Stop the trace

The user can examine answers to previous questions or earlier choices by typing " $W$ " and giving the number of the question. 


\section{SHO(W)-Display previous answers to questions (by number of ques- tion)}

The user can interrupt muPETROL and enter the BREAK condition in muLISP by typing "B."

(B)REAK-Suspend muPETROL and allow user to enter the BREAK condition in muLISP

By typing "Q," the user exits muPETROL and returns to the system.

(Q)UIT-Exit muPETROL and return to system

Appendix B shows the header file for the muPETROL expert system and an explanation for starting the program and the option list for the $\mathbf{1 0}$ models. The first option is the Introduction and Tutorial model, followed by the options for the nine Klemme basin models. If the user is unfamiliar with the Klemme basin classification system or would like to become familiar with the general nature of the geologic queries relative to the basin models, the first option for the Introduction and Tutorial model should be selected. Otherwise, the user can select the option for the basin class that he thinks most closely matches his test basin, or he can run through the complete sequence of basin models.

\section{NEW DEVELOPMENTS}

Work is now in progress to encode the muPETROL basin models into a more powerfully designed expert systems shell, called Knowledge Engineering System II (KESII), that also allows direct numerical input, the assignment of rule strengths and degrees of uncertainty in terms of a geologist's answers and the available geologic information, and input in the form of mathematical formulations. These capabilities are essential for the geologist who must deal with data that are incomplete, interpretive, uncertain, and even unreliable; in frontier areas, little or no data may exist. New developments are also underway in the design of a prototype expert system for a comprehensive sedimentary basin analysis to follow the basin classification system.

Work continues on the compilation of data bases containing geologic data and petroleum statistics (for example, well data, production and reserve data, field-size information, and so on) for selected basins representing the different classes. These data will aid the geologist in using basin analogs to answer the questions asked in matching or classifying basins by the basin models. These data bases can also be called on in determining the historical favorability for petroleum occurretice relative to a particular basin class.

\section{CONCLUSIONS}

This study explores the feasibility of applying the concepts of Artificial Intelligence and knowledge acquisition techniques to building an expert system for classifying, by means of geologic criteria, the sedimentary basins of the world. The Klemme world basin classification system was chosen for this study because, by relating the occurrence of petroleum to basin characteristics, it provides basin analogs for use in forecasting petroleum potential. The sedimentary basin classification system was designed to provide a preliminary evaluation of the regional geology as the first step in a detailed basin analysis. Such an evaluation is usually made in preparation for using most of the appraisal methodologies commonly employed to estimate the undiscovered petroleum resources of a basin, regardless of the basin classification scheme used.

Not only has the expert system technique proved to be a feasible vehicle for applying Klemme's classification of the world's sedimentary basins, but the process of designing the geologic models has also proved to be a very instructive and challenging activity in itself. This process involves the synthesis, into a precise computer language, of the geologic understanding of the global tectonic framework and the genesis of the world's sedimentary basins. The techniques employed also provide new insights into the logic used to define more explicit geologic concepts and the reasoning needed to understand the global tectonics and geologic nature of sedimentary basins. This system in turn provides the preliminary groundwork for the more detailed sedimentary basin studies that are essential to the assessment of our Nation's energy resources.

The experiences gained in this study are both encouraging and critical to the long-term objective of designing an integrated expert system incorporating geologic knowledge-based data systems that will provide complete basin analyses. These basin analyses will be used as input to a variety of energy resource appraisal methods for calculating the remaining undiscovered energy resources in a basin or in limited areas, such as a play analysis within a basin. Such a system will give the user insight into the tasks needed to (1) analyze a sedimentary basin geologically by incorporating all the known and analogous basin information; (2) interpret and relate these basin characteristics to the genetic occurrence and location of energy resources; (3) develop, select, and apply the most credible resource appraisal methods for estimating the energy resources of a basin; and (4) provide complete documentation of the information used, the geologic assumptions made, and the methodology that was applied for any particular assessment. This system may allow for replication of resource assessments and would provide an easy means of updating the 
U.S. Geological Survey's information files for each sedimentary basin.

\section{SELECTED REFERENCES}

Andriole, S.J., ed., 1985, Applications in artificial intelligence: Princeton, N.J., Petrocelli Books, 528 p.

Bally, A.W., 1975, A geodynamic scenario for hydrocarbon occurrences: World Petroleum Congress, 9th, Tokyo 1975, Proceedings, v. 2, p. 33-44.

Bally, A.W., and Snelson, S., 1980, Realms of subsidence, in Miall, A.D., ed., Facts and principles of world petroleum: Canadian Society of Petroleum Geologists Memoir 6, p. 9-94.

Bois, C., Bouche, P., and Pelet, R., 1982, Global geologic history and distribution of hydrocarbon reserves: American Association of Petroleum Geologists Bulletin, v. 66, no. 9, p. $1248-1270$.

Brod, I.O., and Vysotskiy, I.V., eds., 1965, The petroleum basins in the world: Moscow, Nedra, 598 p. [in Russian].

Buchanan, B.G., Barstow, D., Bechtal, R., Bennett, J., Clancey, W., Kulikowski, C., Mitchell, T., and Waterman, D.A., 1983, Constructing an expert system, in HayesRoth, F., Waterman, D.A., and Lenat, D.B., eds., Building expert systems: Reading, Mass., Addison-Wesley, p. 127-168.

Burk, C.A., and Drake, C.L., 1974, The geology of continental margins: New York, Springer-Verlag, 1,009 p.

Duda, R.O., Hart, P.E., Barrett, P., Gaschnig, J.G., Konolige, K., Reboh, R., and Slocum, J., 1978, Development of the PROSPECTOR consultation system for mineral exploration-Final report: Menlo Park, Calif., SRI International, $193 \mathrm{p}$.

Duda, R.O., Gaschnig, J., Reboh, R., and Wilber, B.M., 1981, Operation Manual for the PROSPECTOR consultant system-Final report: Menlo Park, Calif., SRI International, $75 \mathrm{p}$.

Emery, K.O., 1980, Continental margins-Classification and petroleum prospects: American Association of Petroleum Geologists Bulletin, v. 64, no. 3, p. 297-315.

Ennis, S.P., 1983, Expert systems-An emerging computer technology: Oil and Gas Journal, v. 81 , July 25, p. 184-188.

Finch, W.I., Granger, H.S., Lupe, R., and McCammon, R.B., 1980, Genetic-geologic models-A systematic approach to evaluate geologic favorability for undiscovered uranium resources, part $\mathrm{I}$, in Research on uranium resource models, a progress report: U.S. Geological Survey OpenFile Report 80-2018-A, 55 p.

Granger, H.C., Finch, W.I., Kirk, A.R., and Thaden, R.E., 1980, Genetic-geologic model for tabular humate uranium deposits, Grants Mineral Belt, San Juan Basin, New Mexico, part III, in Research on uranium resource models, a progress report: U.S. Geological Survey OpenFile Report 80-2018-C, 58 p.

Halbouty, M.T., King, R.E., Klemme, H.D., Dott, R.H., Sr., and Meyerhoff, A.A., 1970a, Factors affecting formation of giant oil and gas fields, and basin classification, part
II, in Halbouty, M.T., ed., Geology of giant petroleum fields: American Association of Petroleum Geologists Memoir 14, p. 528-555.

Halbouty, M.T., Meyerhoff, A.A., King, R.E., Dott, R.H., Sr., Klemme, H.D., and Shabad, T., 1970b, World's giant oil and gas fields, geologic factors affecting their formation, and basin classification, part I, in Halbouty, M.T., ed., Geology of giant petroleum fields: American Association of Petroleum Geologists Memoir 14, p. 502-528.

Harmon, P., and King, D., 1985, Expert systems: New York, John Wiley, 283 p.

Hayes-Roth, F., Waterman, D.A., and Lenat, D.B., eds., 1983, Building expert systems: Reading, Mass., AddisonWesley, 444 p.

Horak, R.L., 1985, Tectonic and hydrocarbon maturation history in the Permian basin: Oil and Gas Journal, v. 83, no. 21 , p. $124-129$.

Huff, K.F., 1978, Frontiers of world oil exploration: Oil and Gas Journal, v. 76, no. 40 , p. 214-220.

1980, Frontiers of world exploration, in Miall, A.D., ed., Facts and principles of world petroleum: Canadian Society of Petroleum Geologists Memoir 6, p. 344-362.

Kingston, D.R., Dishroon, C.P., and Williams, P.A., 1983a, Global basin classification system: American Association of Petroleum Geologists Bulletin, v. 67, no. 12, p. 2175-2193.

1983b, Hydrocarbon plays and global basin classification: American Association of Petroleum Geologists Bulletin, v. 67 , no. 12 , p. 2194-2198.

1985a, A hydrocarbon exploration crustal classification: Oil and Gas Journal, v. 83, no. 10, p. 146-156.

-1985b, Global basin classification system: Oil and Gas Journal, v. 83 , no. 18 , p. $238-262$.

-1985c, Hydrocarbon plays, global basin classification: Oil and Gas Journal, v. 83, no. 18, p. 265-270.

Klemme, H.D., 1971a, What giants and their basins have in common: Oil and Gas Journal, v. 69, no. 9, p. 85-90.

$-1971 b$, To find a giant, find the right basin: Oil and Gas Journal, v. 69, no. 10, p. 103-110.

1971c, Look in Permian reservoirs or younger to find supergiants: Oil and Gas Journal, v. 69, no. 11, p. 96-100.

1971d, Trends in basin development-Possible economic implications: World Petroleum, v. 42, no. 10, p. 47-51, 54-56.

-1975, Giant oil fields related to their geologic setting-A possible guide to exploration: Bulletin of Canadian Petroleum Geology, v. 23, no. 1, p. 30-36.

1977, World oil and gas reserves from analysis of giant fields and petroleum basins (provinces), in Meyer, R.F., ed., The future supply of nature-made petroleum and gas technical reports: New York, Pergamon, p. 217-260.

1980, Petroleum basins-Classifications and characteristics: Journal of Petroleum Geology, v. 3, no. 2, p. 187-207.

-1983, Field size distribution related to basin characteristics: Oil and Gas Journal, v. 81, no. 26, p. 168-176.

Knebel, G.M., and Rodriguez-Eraso, G., 1956, Habitat of some oil: American Association of Petroleum Geologists Bulletin, v. 40 , no. 4 , p. $547-561$. 
Krystinik, K.B., 1985, An example expert system for the interpretation of depositional environments: U.S. Geological Survey Open-File Report 85-30, 14 p.

McCammon, R.B., 1980, Geologic decision analysis and its application to genetic-geologic models, part II, in Research on uranium resource models, a progress report: U.S. Geological Survey Open-File Report 80-2018-B, 30 p.

1986, The muPROSPECTOR mineral consultant system: U.S. Geological Survey Bulletin 1697, 35 p.

McCammon, R.B., Boudette, E.L., Cameron, C.C., Cox, L.J., and Moench, R.H., 1984, An expert system for mineral resource assessment in the Sherbrooke-Lewiston 1 degree by 2 degree quadrangles, Maine, New Hampshire and Vermont: U.S. Geological Survey Open-File Report 84-751, $37 \mathrm{p}$.

McCrossan, R.G., and Porter, J.W., 1973, The geology and petroleum potential of the Canadian sedimentary basins-A synthesis, in McCrossan, R.G., ed., The future petroleum provinces of Canada-Their geology and potential: Canadian Society of Petroleum Geologists Memoir 1, p. 589-720.

Microsoft, 1986, Microsoft LISP, Artificial Intelligence programming environment for the MS-DOS operating system (muLISP-86): Bellevue, Wash., 400 p.

Miller, B.M., 1979, The evolution in the development of petroleum resource appraisal procedures in the U.S. Geological Survey, in Hydrocarbon Economics and Evaluation Symposium, 8th, Dallas 1979, Society of Petroleum Engineers Publication SPE 7720: Dallas, Society of Petroleum Engineers-American Institute of Mining Engineers, p. 79-90.

-1986a, Building an expert system helps classify sedimentary basins and assess petroleum resources: GEOBYTE, v. 1, no. 2, p. 44-48, 83-84.

1986b, Resource appraisal methods-Choice and outcome, in Rice, D.R., ed., Oil and gas assessment-Methods and applications: American Association of Petroleum Geologists Studies in Geology, no. 21, p. 1-23.

Miller, B.M., Thomsen, H.L., Dolton, G.L., Coury, A.B., Hendricks, T.A., Lennartz, F.E., Powers, R.B., Sable, E.G., and Varnes, K.L., 1975, Geological estimates of undiscovered recoverable oil and gas resources in the United States: U.S. Geological Survey Circular 725, 78 p.

North, F.K., 1971, Characteristics of oil provinces-A study for students: Bulletin of Canadian Petroleum Geology, v. 19 , p. $601-658$.
1979, Episodes of source-sediment deposition, part 1: Journal of Petroleum Geology, v. 2, no. 2, p. 199-218.

Perrodon, A., 1971, Essai de classification des bassins sedementaires [Attempts in the classification of sedimentary basins]: Sciences de la Terre, v. 16, p. 197-227.

1977, Concepts, modeles et logique des bassins sedimentaires [Concepts, models and logic for sedimentary basins]: Bulletin Centres Recherche, ExplorationProduction Elf-Aquitaine, v. 1, p. 111-130.

Reboh, Rene, 1981, Knowledge engineering techniques and tools in the PROSPECTOR environment, in Technical Note 243: Menlo Park, Calif., SRI International, Projects 5821,6415 , and $8172,149 \mathrm{p}$.

St. John, B., Bally, A.W., and Klemme, H.D., 1984, Sedimentary provinces of the world-Hydrocarbon productive and non-productive: Tulsa, Okla., American Association of Petroleum Geologists, scale 1: $50,000,000,35$ p. text.

Stefik, M., Aikins, J., Balzer, R., Benoit, J., Birnbaum, L., Hayes-Roth, F., and Sacerdoti, E., 1982, The organization of expert systems*, a tutorial: Artificial Intelligence, v. 18 , no. 2 , p. $135-173$.

Uspenskaya, N.Yu., 1967, Principles of oil and gas territories subdivision and the classification of oil and gas accumulations, in World Petroleum Congress, 7th, Mexico 1967, Proceedings: Amsterdam, Elsevier, p. 961-969.

Uspenskaya, N.Yu., and Tabasaranski, Z.A., 1966, Petroleum provinces and regions of the USSR: Moscow, Nedra, 495 p. [in Russian].

Uspenskaya, N.Yu., and Tauson, N.M., 1972, Petroleum provinces and regions of the foreign countries: Moscow, Nedra, 295 p. [in Russian].

Waterman, D.A., 1986, A guide to expert systems: Reading, Mass., Addison-Wesley, 419 p

Waterman, D.A., and Hayes-Roth, F., 1983, An investigation of tools for building expert systems, in Hayes-Roth, F, Waterman, D.A., and Lenat, D.B., eds., Building expert systems: Reading, Mass., Addison-Wesley, p. 169-215.

Weeks, L.G., 1952, Factors of sedimentary basin development that control oil occurrence: American Association of Petroleum Geologists Bulletin, v. 36, no. 11, p. 2071-2124.

Weiss, S., Kulikowski, C., Apte, C., Uschold, M., Patchett, J., Brigham, R., and Spitzer, B., 1982, Building expert systems for controlling complex programs, in National Conference on Artificial Intelligence, Proceedings, v. 1: Pittsburg, Pa., American Association for Artificial Intelligence, p. 322-326.

Winston, P. H., and Prendergast, K.A., eds., 1984, The AI business-The commercial uses of artificial intelligence: Cambridge, Mass., MIT Press, 324 p. 
APPENDIXES 



\section{APPENDIX A. -SEDIMENTARY BASIN MODELS USING THE KLEMME WORLD BASIN CLASSIFICATION SCHEME FOR THE MUPETROL EXPERT SYSTEM}

\section{Introduction}

The prototype expert system muPETROL is comprised of sedimentary basin models constructed for nine sedimentary basin types or classes as defined by Klemme for a world sedimentary basin classification scheme (Klemme, 1980; written communication, 1985, 1986). In addition, an Introduction and Tutorial model is designed to aid in using the muPETROL expert system and also to familiarize the user with the basic geologic attributes and concepts used by Klemme for classifying world basins.

The basin models are encoded in a form compatible with muPROSPECTOR II (McCammon, 1986). An evaluation using muPETROL consists of a probabilistic estimate of the likelihood of occurrence of the basin type being considered, coupled with the reasons on which the evaluation is based. Each evaluation takes into account the geologic evidence judged favorable or unfavorable.

This guide is intended for the reader who wishes to use the existing basin models in muPETROL or for those users who wish to build their own models.

\section{Sedimentary Basin Models}

The Introduction and Tutorial model and the nine sedimentary basin models are listed by the following basin identifications and file codes in the menu of options for the user to select in running the muPETROL expert system.

\begin{tabular}{|c|c|c|}
\hline Name & $\begin{array}{l}\text { Basin } \\
\text { model } \\
\text { number }\end{array}$ & File code \\
\hline 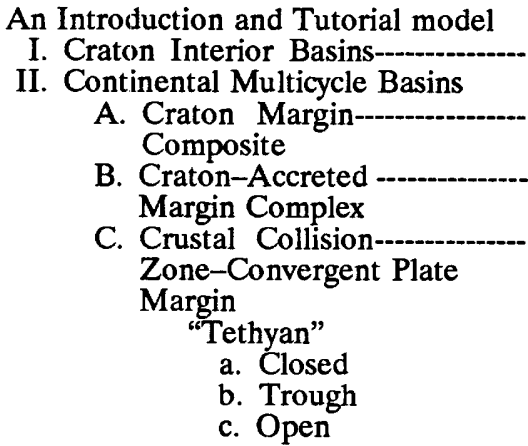 & $\begin{array}{l}2 \\
3 \\
4\end{array}$ & $\begin{array}{l}\text { START } \\
\text { CRATON } \\
\text { IIAMARG } \\
\text { IIBCAMB }\end{array}$ \\
\hline $\begin{array}{l}\text { III. Continental Rifted Basins } \\
\text { A. Craton and Accreted--.-.-- } \\
\text { Zone Rift } \\
\text { B. Rifted Convergent--..-.-.-- } \\
\text { Margin } \\
\text { "Pacific" } \\
\text { a. Back arc } \\
\text { b. Transform } \\
\text { c. Median }\end{array}$ & 5 & CAZR \\
\hline
\end{tabular}

\begin{tabular}{|c|c|c|}
\hline Name & $\begin{array}{c}\text { Basin } \\
\text { model } \\
\text { number }\end{array}$ & File code \\
\hline $\begin{array}{l}\text { III. Continental Rifted Basins-Contin } \\
\text { C. Rifted Passive Margin--...- } \\
\text { "Atlantic" } \\
\text { a. Parallel } \\
\text { b. Transform }\end{array}$ & ${ }_{7}$ & RPM \\
\hline $\begin{array}{l}\text { IV. Delta Basins-Tertiary to--........ } \\
\text { Recent } \\
\text { a. Synsedimentary } \\
\text { b. Structural }\end{array}$ & 8 & DELTA \\
\hline V. Forearc Basins-- & 9 & FOREAC \\
\hline
\end{tabular}

The computer listings, identified by file code, and the inference net diagrams for the Introduction and Tutorial model and for the nine sedimentary basin models are documented in appendixes B through L. A transcript of a trial run for Option 1 (Introduction and Tutorial model) is given in appendix C-2. A source listing for the expert system shell taken from the muPROSPECTOR II version was published by McCammon and others (1984, appendix C).

\section{Availability and Future Developments in the mUPETROL Expert System}

muPETROL is an operational prototype expert system presently consisting of 10 computer models designed to classify world sedimentary basins. These 10 models, encoded for the muLISP muPROSPECTOR system, are available to the public on diskettes. ${ }^{1}$ However, in constructing these basin models, I concluded that more detailed work leading to a comprehensive basin analysis system useful for assessing all energy and mineral resources of sedimentary origin requires a more powerfully designed expert system for direct numerical input, the assignment of rule strengths and degrees of uncertainty, and direct access to additional external computer systems and data files. Therefore, this prototype program is being revised and encoded for the KESII (Knowledge Engineering System II) expert system as the initial phase of a more detailed sedimentary basin analysis technique for assessing resources.

\footnotetext{
${ }^{1}$ Copies are available through the U.S. Geological Survey Books and Open-File Reports Section, Federal Center, Box 25425, Denver, CO 80225.
} 
APPENDIX B.-HEADER FILE FOR THE MUPETROL EXPERT SYSTEM

TITLE $\quad{ }^{*}$ WORLD BASIN CLASSIFICATION SYSTEM

FOR PETROLEUM RESOURCE APPRAISAL

DESIGNED BY BETTY M. MILLER */

HELLO $/^{*}$ I am here to assist you in classifying your sedimentary basin in order to appraise its potential for hydrocarbon resources. */

PURPOSE /* This is the first phase of a prototype expert system, called muPETROL, designed by Betty M. Miller, to assist in classifying the sedimentary basins of the world by using the Klemme world basin classification scheme with respect to the petroleum potential of the basin. */

FILENAMES /* START CRATON IIAMARG IIBCAMB CCZM CAZR RCM RPM DELTA FOREAC */

OBJLST $/^{*} \longrightarrow$ An Introduction and Tutorial

I -...--Craton Interior Basins

IIA ---Craton Margin Composite Basins

IIB ---Craton-Accreted Margin Complex Basins

IIC ---Crustal Collision Zone-Convergent Plate Margin Basins

IIIA--Craton and Accreted Zone Rift Basins

IIIB --Rifted Convergent Margin Basins

IIIC--Rifted Passive Margin Basins

IV ----Delta Basins

V------Forearc Basins */

BANNER /* WORLD BASIN CLASSIFICATION *

OBJECT $/ *$ basin */ ATTRIBUTE $/ *$ area */STOP 


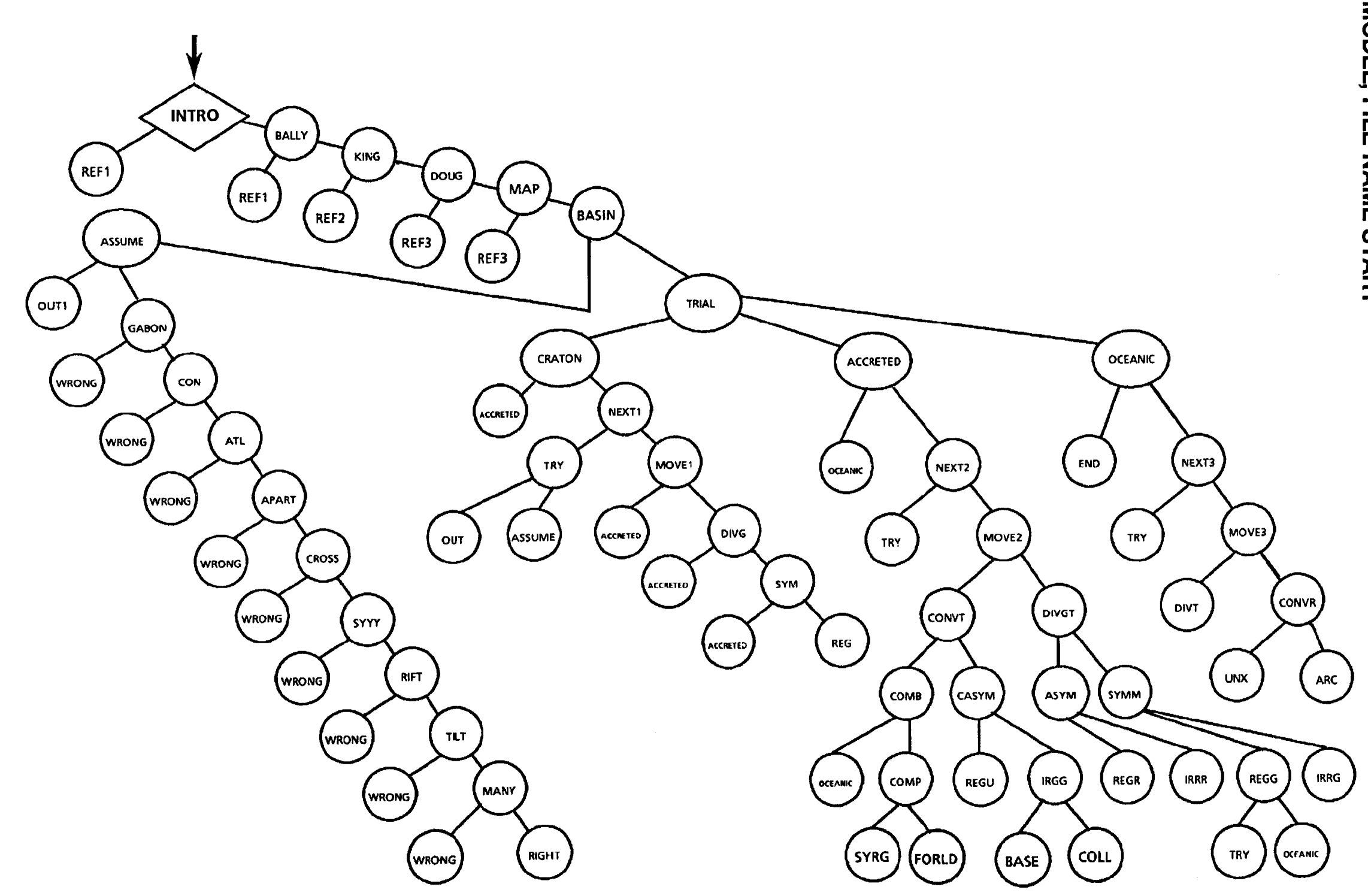

$\vec{\omega} \quad$ Inference net for Introduction and Tutorial model, file name START. 
model START

topspace INTRO

space INTRO desc $/ *$ Familiar with world sedimentary basin classifications */

announce $/^{*}$ This is an introductory approach to determine how familiar you are with the concepts of classifying the world's sedimentary basins relative to plate tectonics. *I

ques $/ *$ ARE YOU FAMILIAR WITH THE GEOLOGIC CONCEPTS USED IN SOME OF THE BET-

TER KNOWN WORLD SEDIMENTARY BASIN CLASSIFICATION SYSTEMS */

expl $/^{*}$ I am trying to determine if you are familiar with the basic geologic concepts that are used to classify the world's sedimentary basins, and if you are familiar with any of the more commonly known classification systems. */ yes BALLY no REF1

space REF1 desc /* Referral to basin classification sources */

inf $/^{*}$ It would appear that you are unfamiliar with the basic geologic concepts used to classify the world's sedimentary basins. I would recommend that you read the following references to develop a general background to basin classification before you attempt to run the muPETROL system: (1) Weeks, L.G., 1952, Factors of sedimentary basin development that control oil occurrence: AAPG Bull., v. 36, p. 2071-2124. (2) Bally, A.W., and Snelson, S., 1980, Realms of subsidence, in Miall, A.D., ed., Facts and principles of world petroleum occurrence: Canadian Society of Petroleum Geologists Memoir 6, p. 9-75. (3) Klemme, H.D., 1971, Giants, supergiants and their relation to basin types, Oil and Gas Journal: March 1, March 8, and March 15 editions, 14 p. */

space BALLY desc /* Familiar with the Bally-Snelson world basin classification system */

ques ${ }^{*}$ ARE YOU FAMILIAR WITH THE BASIC GEOLOGIC CONCEPTS OF THE BALLY-SNELSON WORLD BASIN CLASSIFICATION SYSTEM THAT WAS PUBLISHED IN 1980 BY THE CANADIAN SOCIETY OF PETROLEUM GEOLOGISTS MEMOIR $6 * /$

expl /*I am trying to determine which of the world basin classification systems that you may be familiar with relative to their respective geologic concepts. */ yes KING no REF1

space KING desc /* Familiar with the Kingston et al. world basin classification system */

ques $/ *$ ARE YOU FAMILIAR WITH THE BASIC GEOLOGIC CONCEPTS FOR THE KINGSTONDISHROON-WILLIAMS WORLD BASIN CLASSIFICATION SYSTEM THAT WAS PUBLISHED IN $1983 * /$ expl $/^{*}$ I am trying to determine if you are familiar with the works of Kingston, Dishroon, and Williams with Exxon, published in 1983 (AAPG) and 1985 (Oil and Gas Jour.), for classifying world sedimentary basins. */ yes DOUG no REF2

space REF2 desc /* Referral to world basin classification references of Kingston et al .*/

inf $/^{*}$ It would appear that you are unfamiliar with the Kingston et al. world basin classification system. I would recommend that you check the following references: (1) Kingston, D.R., Dishroon, C.P., and Williams, P.A., 1983, Global basin classification system, AAPG, v. 67, no. 12, p. 2175-2193. (Also published in the Oil and Gas Journal, May 6, 1985, p. 238-262.), (2) Kingston et al., 1983, Hydrocarbon plays and global basin classification, AAPG, v. 67, no. 12, p. 2194-2198. (Also published in the Oil and Gas Journal, May 6, 1985, p. 265-270.) */

space DOUG desc /* Familiar with the Klemme world basin classification system */ ques $/ *$ ARE YOU FAMILIAR WITH THE BASIC GEOLOGIC CONCEPTS OF THE KLEMME WORLD BASIN CLASSIFICATION SYSTEM AS RELATED TO PETROLEUM OCCURRENCE */

expl $/^{*}$ I am trying to determine if you are familiar with the basic geologic concepts and related concepts of petroleum occurrence that are incorporated into the many publications of H.D. Klemme since the early 1970's. */ yes MAP no REF3

space MAP desc $/^{*}$ Familiar with the map showing the sedimentary provinces of the world and the tectonic plate boundaries */ 
ques $/^{*}$ ARE YOU FAMILIAR WITH ANY OF THE VARIOUS MAPS SHOWING THE SEDIMENTARY PROVINCES OR BASINS OF THE WORLD AND THE LOCATION OF THE GLOBAL PLATE BOUNDARIES */

expl $/^{*}$ I am trying to determine if you are familiar with the locations of the world's sedimentary provinces or basins relative to the tectonic plate boundaries as shown in maps published by Klemme, Bally, St. John, and others. */ yes BASIN no REF3

space REF3 desc /* Referral to world basin classification references by H.D. Klemme */

inf $/^{*}$ It would appear that you are unfamiliar with the Klemme world basin classification system. I would recommend that you check the following references that address the various concepts of Klemme's basin classification system relative to petroleum occurrence or have used Klemme's classification system in their work. (1) Halbouty, M.T., Meyerhoff, A.A., King, R.E., Dott, R.H., Sr., Klemme, H.D., and Shabad, T., 1970, World's giant oil and gas fields, geologic factors affecting their formation, and basin classification, part I, in Halbouty, M.T., ed, Geology of giant petroleum fields: AAPG, Memoir 14, p. 502-528. (2) Halbouty, M.T., King, R.E., Klemme, H.D., Dott, R.H., Sr., and Meyerhoff, A.A., 1970, part II, Factors affecting formation of giant oil and gas fields, and basin classification, in the same publication as above. (3) Klemme, H.D., 1971, Giants, supergiants and their relation to basin types: Oil and Gas Journal, March 1, v. 69, no. 9, p. 85-90, March 8, v. 69, no. 10, p. 103-110, March 15, v. 69, no. 11, p. 96-100. World basin map included. (4) Klemme, H.D., 1971, Trends in basin development-Possible economic implications: World Petroleum, v. 42, no. 10, p. 47-51, 54-56. (5) Klemme, H.D., 1975, Giant oil fields related to their geologic setting-A possible guide to exploration: Bull. Canadian Petroleum Geology, v. 23, no. 1, p. 30-36. (6) Klemme, H.D., 1977, World oil and gas reserves from analysis of giant fields and petroleum basins (provinces), in Meyer, R.F., ed., The future supply of nature-made petroleum and gas technical reports: sponsored by UNITAR and IIASA, Pergamon Press, p. 217-260. (7) Klemme, H.D., 1980, Petroleum basins-Classifications and characteristics: Journal of Petroleum Geology, v. 3, no. 2, p. 187-207. (8) Klemme, H.D., 1983, Field size distribution related to basin characteristics: Oil and Gas Jour, v. 81, no. 26, p. 168-176. (9) St. John, W., Bally, A.W., and Klemme, H.D., 1984, Sedimentary provinces of the world-Hydrocarbon productive and nonproductive: AAPG, $35 \mathrm{p}$., and accompanying map, Sedimentary provinces of the world, scale 1:50,000,000. */

space BASIN desc $/ *$ Identification of a test basin */

ques $/ *$ DO YOU HAVE A SEDIMENTARY BASIN IN MIND THAT YOU WOULD LIKE TO USE AS A TEST BASIN THAT WE COULD USE AS AN EXAMPLE FOR AN INTRODUCTORY TRIAL RUN TO ILLUSTRATE THE BASIN CLASSIFICATION TECHNIQUE */

expl $/^{*}$ I would like to determine if you have a specific sedimentary basin in mind that we could use as an example for an introductory trial run to illustrate the basics of a Klemme basin classification. If so, answer YES. If you would rather that I provide the example basin for a trial run, please answer NO. */ yes TRIAL no ASSUME

space TRIAL desc $/^{*}$ Location of test basin relative to its position on continental, accreted margin, or oceanic crust $* /$

expl $/^{*}$ I am trying to determine if you know the actual position of your basin relative to the major crustal zones, such as a location on continental or accreted craton margin versus oceanic crust. */

announce $/ *$ The following is intended to aid you in the first step to classifying your sedimentary basin. $* /$

choices $/ *$ CRATON ACCRETED OCEANIC */

space CRATON desc /* Evidence of a continental basin located on an interior craton */

noun-phrase $/ *$ Continental Cratonic Basin */

ques $/ *$ IS YOUR BASIN LOCATED ON AN INTERIOR CONTINENTAL PLATE OR CRATON * $/$

$\operatorname{expl} / *$ I am trying to determine if your basin is located entirely within an old cratonic interior, probably near exposed Precambrian shield areas of continental crustal plate, as opposed to being located on an accreted craton margin or in an oceanic crustal position. */ yes NEXT1 no ACCRETED

space NEXT1 desc $/ *$ Evidence of a continental cratonic basin */ 
announce $/^{*}$ Congratulations! You have decided that you may have a continental interior cratonic basin. The following questions will help you to understand the next steps in the decisionmaking process for the Klemme basin classification system. $*$ I

ques $/ *$ DO YOU KNOW THE TYPE OF PAST PLATE MOVEMENT THAT WAS INVOLVED IN THE AREA OF YOUR BASIN FORMATION (DIVERGENT OR CONVERGENT) *

expl $/^{*}$ I am trying to determine if you know what type of past plate movement has taken place in the area of your basin's formation. You may have had either divergent or convergent plate movements involved in your basin's formation, or you may have some combination of these two plate movements in your basin's complex history. $* /$ yes MOVE1 no TRY

space TRY desc $/^{*}$ Favorable to the suggestion of trying the test basin provided in this introduction to basin classification */

announce $/ *$ If you are not sure of the plate movement in the area of the basin of your choice, you may wish to try the test basin provided in this introduction to basin classification techniques. */

ques /* WOULD YOU LIKE TO TRY CLASSIFYING THE TEST BASIN THAT IS PROVIDED IN THIS INTRODUCTION TO BASIN CLASSIFICATION TECHNIQUES */

expl /* If you answer YES to this question, then you may continue with the next steps in this classification system. If you answer NO, then you will exit from this exercise. You may wish to try again with another basin selection. */ yes ASSUME no OUT

space OUT desc $/ *$ Suggestions to the user */

inf $l^{*}$ It would appear that you are missing key information about the basin of your choice, and you have chosen not to try the test basin provided in this introduction to the basin classification technique. Therefore, I would recommend that you either rerun this Introduction model and select a different basin on which you may have more available geologic information, or you reconsider and try the test basin. You might want to strike out on your own and select one of the nine basin models to run for the basin of your choice, OR you might want to just forget the whole thing and call it a day. Good Luck! */

space ACCRETED desc /* Evidence of a continental basin located on an accreted craton margin */

noun-phrase $/ *$ Continental Craton-Accreted Margin Basin */

ques $/ *$ IS YOUR BASIN LOCATED ON AN ACCRETED ZONE NEAR THE MARGIN OF A CONTINENTAL PLATE OR CRATON */

expl /* I am trying to determine if your basin is located on an accreted zone which has been added to the margins of the old continental craton by Phanerozoic welding of displaced terranes or microplates (expressed in the past as "mobile belts," "eugeosynclines," "foldbelts," "sutures," and "megasutures"), as opposed to an interior cratonic location or an oceanic crustal position. */ yes NEXT2 no OCEANIC

space NEXT2 desc $/ *$ Evidence of a continental craton-accreted margin basin */

announce $/ *$ Congratulations! You have decided that you may have a continental craton accreted margin basin. The following questions will help you to understand the next steps in the decisionmaking process for this basin classification system. */

ques $/ *$ DO YOU KNOW THE TYPE OF PAST PLATE MOVEMENT THAT WAS INVOLVED IN THE AREA OF YOUR BASIN FORMATION (DIVERGENT OR CONVERGENT) */

expl $/^{*}$ I am trying to determine if you know what type of past plate movement has taken place in the area of your basin's formation. You may have had either divergent or convergent plate movements involved in your basin's formation, or you may have some combination of these two plate movements in your basin's complex history. */ yes MOVE2 no TRY

space OCEANIC desc /* Evidence of the basin as an oceanic basin located on oceanic crust, or primarily on oceanic crust */

noun-phrase $/^{*}$ Oceanic (or partly oceanic) Basins */ 
ques $/ *$ IS YOUR BASIN LOCATED ON AN OCEANIC PLATE OR AN ACCRETED MARGIN PARTIALLY OVERLYING AN OCEANIC PLATE OR CRUST *

expl $/^{*}$ I am trying to determine if your basin is located entirely on oceanic crust or on an accreted cratonic margin that overlies or partially overlies oceanic crust, as opposed to being located on a continental craton or on an accreted continental margin. */ yes NEXT3 no END

space NEXT3 desc $/ *$ Evidence of an oceanic basin or a basin located partially on oceanic crust */

announce $/^{*}$ Congratulations! You have decided that you may have an oceanic basin, or a basin located partially on oceanic crust. The following questions will help you to understand the next steps in the decisionmaking process for this basin classification system. $*$ /

ques $/ *$ DO YOU KNOW THE TYPE OF PAST PLATE MOVEMENT THAT WAS INVOLVED IN THE AREA OF YOUR BASIN FORMATION (DIVERGENT OR CONVERGENT) */

$\operatorname{expl} /^{*}$ I am trying to determine if you know what type of past plate movement has taken place in the area of your basin's formation. You may have either divergent or convergent plate movements involved in your basin's formation, or you may have some combination of these two plate movements in your basin's complex history. */ yes MOVE3 no TRY

space MOVE1 desc $/ *$ Evidence of a divergent, continental, interior cratonic basin */

ques $/ *$ IS YOUR CRATON INTERIOR BASIN LOCATED ON A CONTINENTAL CRUST THAT HAS BEEN SUBJECTED TO PRIMARILY DIVERGENT (OR EXTENSIONAL) PLATE MOVEMENTS, AS OPPOSED TO CONVERGENT (OR COMPRESSIONAL) PLATE MOVEMENTS */

expl $/^{*}$ I am trying to determine whether the basin that you have described thus far, a continental interior cratonic basin, is located on a continental plate or crust that has experienced divergent plate movement or extensional regional stress. */ yes DIVG no ACCRETED

space DIVG desc $/ *$ Evidence of a symmetrical, continental interior cratonic basin */

ques $/^{*}$ DOES YOUR BASIN HAVE A SYMMETRICAL PROFILE OR CROSS SECTION ACROSS THE BASIN AT CONTACT OF SEDIMENTS WITH BASEMENT */

expl $/^{*}$ I am trying to determine if your interior cratonic basin has a symmetrical profile or cross section across the basin at the sediment-basement contact, as opposed to your basin having an asymmetrical profile. $* /$ yes SYM no ACCRETED

space SYM desc $/ *$ Evidence of a regular, symmetrical cratonic basin */

ques $/ *$ DOES THE PROFILE OF YOUR BASIN HAVE A REGULAR (OR SMOOTH) SEDIMENT-TOBASEMENT CONTACT WITH LITTLE OR NO RIFT FAULTING EVIDENT, AS OPPOSED TO AN IRREGULAR BASEMENT CONTACT DUE TO RIFTING OF THE BASEMENT */

expl /* I am trying to determine if your basin has had little or no rift faulting to modify the regular basement contact. */ yes REG no ACCRETED

space REG desc /* Evidence of a Klemme I-Craton Interior Basin */

inf $f^{*}$ I think you have sampled enough of the type of geologic questions that you would be asked if you had a Craton Interior Basin that is classified as a Klemme Class I basin. Assuming that you have such a basin to classify, I would recommend that you return to the Option Menu and select the model entitled I-Craton Interior Basins for a more detailed description. Good Luck! */

space MOVE2 desc /* Evidence of a divergent, continental craton accreted margin basin */

qules $/ *$ WAS THE FORMATION OF YOUR CONTINENTAL CRATON ACCRETED MARGIN BASIN IN AN AREA WHERE THE PAST PLATE MOVEMENT HAS BEEN PRIMARILY DIVERGENT OR EXTENSIONAL, AS OPPOSED TO CONVERGENT (OR COMPRESSIONAL) */

expl /* I am trying to determine whether the origin of your continental craton accreted margin basin was in an area involved primarily in divergent plate movements, rather than in an area that was primarily involved in 
space DIVGT desc $/^{*}$ Evidence of a symmetrical, divergent continental craton accreted margin basin */

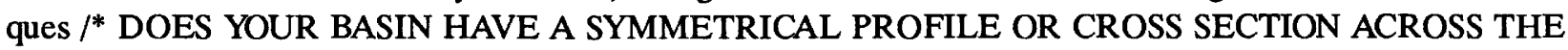
BASIN AT THE CONTACT OF THE SEDIMENTS WITH THE BASEMENT $*$ /

expl $/ *$ I am trying to determine if your divergent, continental craton accreted margin basin has a symmetrical profile or cross section at the sediment-to-basement contact, as opposed to an asymmetrical basin profile. $* /$ yes SYMM no ASYM

space SYMM desc $/ *$ Evidence of an irregular, symmetrical basin */ ques $/ *$ DOES YOUR BASIN HAVE AN IRREGULAR OR FAULTED SEDIMENT-BASEMENT CONTACT WITH RIFT FAULTING, AS OPPOSED TO A REGULAR (SMOOTH) SEDIMENT-BASEMENT CONTACT WITH LITTLE OR NO FAULTING */

expl /* I am trying to determine whether your basin has an irregular basement profile due to rift faulting, rather than a symmetrical basin that has a regular sediment to basement contact with no major rift faulting. */yes IRRG no REGG

space IRRG desc $/ *$ Evidence of a Klemme Class IIB or Class IIIA basin */

inf $l^{*}$ I think you have sampled enough of the questions to become familiar with the type of geologic information that is requested as a start to classifying divergent, irregular symmetrical continental craton accreted margin basins. You have a good possibility of your basin being in the Klemme IIB Class or the IIIA Class. I would recommend that you go back to the Options Menu and select either the model for IIB-Craton-Accreted Margin Complex Basins or the model for IIIA-Craton and Accreted Zone Rift Basins for a more detailed description. Have fun. Good Luck! */

space REGG desc /* Insufficient evidence relative to basin for classification */

announce $/^{*}$ It would appear that you either have insufficient geologic information relative to the deep subsurface nature of your basin, or your basin may be in the Craton or in the Oceanic categories instead. */ ques $/ *$ WOULD YOU LIKE TO TRY EITHER THE CRATON BASIN CATEGORY, OR THE OCEANIC BASIN CATEGORY FOR A BASIN CLASSIFICATION */

expl /* If you would like to check out these other two basin categories, please answer Yes. If not, then answer No. */yes OCEANIC no TRY

space ASYM desc /* Evidence of an asymmetrical, irregular basin */

ques $/ *$ DOES YOUR BASIN HAVE AN IRREGULAR SEDIMENT TO BASEMENT CONTACT DUE TO RIFT FAULTING, AS OPPOSED TO A BASIN WITH A REGULAR OR SMOOTH BASEMENT CONTACT WITH LITTLE OR NO FAULTING */

expl /* I am trying to determine whether your asymmetrical, divergent, continental, craton accreted margin basin has an irregular basin profile due to rift faulting, rather than an asymmetrical basin with a regular or smooth profile with little or no faulting. */yes IRRR no REGR

space IRRR desc $/ *$ Evidence of a Klemme Class IIIC or IV basin */

inf $l^{*}$ I think you have sampled enough questions to get the idea regarding the type of geologic information that is needed in the early steps of classifying an irregular, asymmetrical, divergent, continental craton accreted margin basin. Your test basin is probably a Klemme Class IIIC basin, or possibly a Class IV basin. I would recommend that you go back to the Options Menu and select either the basin model IIIC-Rifted Passive Margin Basins or model IV-Delta Basins for a more detailed description. Good Luck! */

space REGR desc /* Evidence of a Klemme Class IV basin */

inf $l^{*}$ I think you have sampled enough questions to get the idea regarding the type of geologic information that is needed in the early steps of classifying a regular, asymmetrical, divergent, continental craton accreted margin 
basin. Your test basin is probably a Klemme Class IV basin. I would recommend that you go back to the Options Menu and select the basin model IV-Delta Basins for a more detailed description. Good Luck! */

space CONVT desc $/ *$ Evidence of a convergent, continental craton accreted margin basin */

ques ${ }^{*}$ WAS YOUR BASIN LOCATED IN AN AREA WHERE THE PAST PLATE MOVEMENT

INVOLVED IN THE FORMATION OF YOUR BASIN WAS PRIMARILY CONVERGENT (COMPRESSION, COLLISION, OR CONSUMPTION), AS OPPOSED TO A COMPOSITE BASIN THAT HAS EXPERIENCED BOTH MAJOR DIVERGENT AND CONVERGENT PLATE MOVEMENTS */

expl $/^{*}$ I am trying to determine whether your test basin has experienced primarily convergent plate movements relative to the origin of the basin. Convergent plate movements could be either compressional as in the consumption of two plate margins, or as in the collision of two plate margins. If so, answer Yes. However, if your basin has experienced both major divergent (extensional) movements and major convergent (compressional) movements over a complex history of the basin, please answer No. */yes CASYM no COMB

space CASYM desc /* Evidence of an asymmetrical, convergent continental craton accreted margin basin */

ques $/ *$ DOES YOUR CONVERGENT BASIN BASICALLY HAVE AN ASYMMETRICAL BASIN PROFILE OR CROSS SECTION RELATIVE TO THE SEDIMENT TO BASEMENT CONTACT, AS OPPOSED TO A SYMMETRICAL BASIN PROFILE */

expl $/^{*}$ I am trying to determine if the profile or cross section of your basin at the sediment-basement contact is essentially asymmetrical in shape, rather than a basin whose shape is basically symmetrical. */ yes IRGG no REGU

space REGU desc /* Evidence of a convergent symmetrical basin */

$\inf /^{*}$ I think you may be missing some essential geologic information relative to the subsurface of your basin. If you wish to assume that you do have a symmetrical convergent-type basin, I would recommend that you return to the Options Menu and select the basin model IIIB-Rifted Convergent Margin Basins for a more detailed description. Within various stages of this complex basin you could possibly have a symmetrical, convergent-type basin. Good Luck! */

space IRGG desc $/ *$ Evidence of an irregular, asymmetrical, convergent basin */

ques $/ *$ DOES YOUR ASYMMETRICAL, CONVERGENT BASIN HAVE AN IRREGULAR SEDIMENT TO BASEMENT CONTACT DUE TO MAJOR RIFT FAULTING, AS OPPOSED TO A REGULAR SEDIMENT TO BASEMENT CONTACT WITH LITTLE OR NO FAULTING */

expl /* I am trying to determine if your basin has an irregular sediment-basement contact due to faulting, rather than a regular sediment-basement contact with little or no faulting. */ yes COLL no BASE

space COLL desc $/ *$ Evidence of a collision or consumption type basin */

inf $/^{*}$ I think that you have sampled enough questions to get the idea of the type of geologic information that is needed in the early steps of classifying your irregular, asymmetrical, convergent continental craton accreted margin basin. I would recommend that you return to the Options Menu and select either one of the following basin models: IIC-Crustal Collision Zone-Convergent Plate Margin Basins or IIIB-Rifted Convergent Margin Basins for a more detailed description. Have fun. Good Luck! */

space BASE desc $/ *$ Evidence of an asymmetrical, regular convergent-type basin */

inf $/^{*}$ There seems to be little or no evidence within the Klemme system of a regular convergent-type basin in which there has been little or no faulting or folding taking place. You may be missing essential subsurface geologic information for your basin or you may have a basin in its very early stages of formation. I would recommend that you either try some of the other options in this exercise, or you return to the Options Menu and try a basin model that you think might represent the class of your basin. Good Luck! */ 
space COMB desc $/^{*}$ Evidence of a basin having experienced both major divergent and convergent plate movements $*$

ques $/ *$ DO YOU HAVE A CONTINENTAL ACCRETED MARGIN BASIN THAT HAS BEEN SUBJECTED TO BOTH MAJOR DIVERGENT AND THEN CONVERGENT PLATE MOVEMENTS (EXTENSIONAL FOLLOWED BY COMPRESSIONAL REGIONAL STRESS), AS OPPOSED TO FIRST CONVERGENT PLATE MOVEMENTS FOLLOWED BY DIVERGENT PLATE MOVEMENTS */

expl $/^{*}$ I am trying to determine if your basin has been subjected first to major divergent or extensional plate movements, followed by major convergent or compressional plate movements. If so, answer Yes. However, if your basin has been subjected first to major convergent or compressional movements, followed by divergent or extensional movements, answer No. This case might be an oceanic type basin. */yes COMP no OCEANIC

space COMP desc $/ *$ Evidence of an asymmetrical, irregular convergent-type basin */

ques $/ *$ DO YOU HAVE A CONVERGENT-TYPE ACCRETED MARGIN BASIN THAT IS BOTH ASYMMETRICAL IN PROFILE OR CROSS SECTION AND HAS AN IRREGULAR SEDIMENT-TO-BASEMENT CONTACT DUE TO RIFT FAULTING AND FOLDING, AS OPPOSED TO A REGULAR, SYMMETRICAL BASIN */

expl $/^{*}$ I am trying to determine if your convergent basin is both asymmetrical in shape and has an irregular sediment-basement contact due to rift faulting and/or folding. If your basin doesn't have BOTH of these characteristics then answer No. */yes FORLD no SYRG

space FORLD desc $/ *$ Evidence of a Klemme Class IIA basin */

$\inf /^{*}$ I think you have sampled enough questions about your continental, accreted margin basin that has been subjected to both divergent and convergent regional stresses to get the idea of the types of geologic information needed in the early steps of classifying your basin. You probably have a Klemme Class IIA basin. I would recommend that you return to the Options Menu and select basin model IIA-Craton Margin Composite Basins for a more detailed description to check out your basin. Good Luck! */

space SYRG desc $/ *$ Insufficient information on test basin */

inf $/^{*}$ I think that you may be missing some essential subsurface geologic information for your test basin. At any rate you should now have a good idea of the type of geologic information that is needed in the early steps of classifying a basin. I would recommend that you rerun this option and either try another basin OR use the test basin provided in this exercise, OR return to the Options Menu and try one of the more detailed Klemme class models for your basin. Good Luck! */

space MOVE3 desc $/ *$ Evidence of a convergent oceanic or partially oceanic basin */

ques ${ }^{*}$ IS YOUR BASIN LOCATED OFFSHORE AND ON CONVERGENT OCEANIC PLATE MARGINS, AS OPPOSED TO A LOCATION ON DIVERGENT PLATE MARGINS */

expl /* I am trying to determine if your basin is located offshore, on oceanic crust and at the margins of two or more converging plates, rather than being located on diverging plates. */yes CONVR no DIVT

space DIVT desc /* Evidence of a divergent, oceanic basin */

inf $/^{*}$ It would appear that your basin is an oceanic sag that is formed by the separation of two plates where oceanic crust has been formed. Like oceanic trench and trench associated basins, oceanic sags would appear to have limited hydrocarbon potential and are not considered significant petroleum basins. I would recommend that you select a different test basin for classification, or rerun this exercise and use the test basin provided. Good Luck! */

space CONVR desc $/ *$ Evidence of Forearc basins */

ques $/ *$ IS YOUR BASIN LOCATED OFFSHORE ALONG ACTIVE CONVERGENT OCEANIC PLATE MARGINS WHERE THE OCEANIC PLATE IS BEING CONSUMED BY SUBDUCTION, AND THE BASIN IS LOCATED IN AN AREA USUALLY DESCRIBED AS A TRENCH, FOREARC, AND BACKARC SITUATION */ 
expl /* I am trying to determine if the area of your basin can be described as a trench-forearc-backarc geologic situation where several different types of basins may be formed of the forearc and backarc variety with oceanic trenches. */yes ARC no UNX

space ARC desc /* Evidence of Klemme Class V, convergent oceanic basins */

inf $l^{*}$ You have sampled enough questions to get the idea of the kind of geologic information that is needed in the early steps of classifying a convergent, oceanic basin. Your basin is probably a Klemme Class V basin. I would recommend that you return to the Options Menu and select basin model V-Forearc Basins for a more detailed description. Good Luck! */

space UNX desc $/ *$ Insufficient evidence for type of oceanic basin */

$\inf /^{*}$ It would appear that you are missing some essential geologic information to continue the classification of your oceanic basin. However, you have sampled enough questions to get the idea of the kind of geologic information that is needed in the early steps of classifying a convergent oceanic basin. I would recommend that you rerun this exercise and select a different basin OR run the test basin provided OR return to the Options Menu and select the basin model V-Forearc Basins for a more detailed description. Good Luck! */

space ASSUME desc /* Favorable assumption for running test basin as provided */

ques ${ }^{*}$ THE TEST BASIN PROVIDED IN THIS EXERCISE IS THE GABON BASIN ON THE WEST COAST OF AFRICA. WOULD YOU LIKE TO FOLLOW THE INITIAL STEPS IN CLASSIFYING THIS BASIN *I

expl /* You indicated that you did not have a specific basin of your own selection that you wanted to run for a basin classification exercise. Therefore, I am providing a test basin to be run in following the initial steps in using the Klemme classification system. If you wish to run the Gabon basin as the test basin, answer Yes. */ yes GABON no OUT1

space GABON desc $/ *$ Evidence of basin location */

announce $/^{*}$ The Gabon basin is located along the western coast of central Africa, in the country of Gabon. It is basically a continental margin basin bordering the eastern Atlantic Ocean. */

ques $/^{*}$ IS THE GABON BASIN LOCATED PRIMARILY ON A CONTINENTAL CRUSTAL PLATE AS OPPOSED TO BEING LOCATED ON AN OCEANIC PLATE */

expl /* I am trying to determine whether the Gabon Basin is considered a continental basin (or continental margin basin in this case) as opposed to being an oceanic basin. */yes CON no WRONG

space WRONG desc $/ *$ Incorrect answer relative to the Gabon Basin */

inf $/^{*}$ I am sorry but you have answered the question incorrectly relative to the known regional geology of the Gabon Basin. I would suggest that you review the regional geology of the Gabon Basin and rerun this exercise, OR rerun this exercise and select a basin whose geology you are more familiar with. Have fun. Good Luck! */

space CON desc $/ *$ Evidence of an Atlantic continental margin basin */

ques $/ *$ IS THE GABON BASIN BORDERING ON A PRESENT-DAY ATLANTIC CONTINENTAL MARGIN AS OPPOSED TO A COASTAL AREA BORDERING THE CIRCUM-PACIFIC OCEAN */

expl /* I am trying to determine the location of the Gabon Basin relative to its continental margin bordering the Atlantic rather than the Pacific Ocean. */ yes ATL no WRONG

space ATL desc $/ *$ Evidence of a divergent basin */

ques $/ *$ IS THE GABON BASIN LOCATED ON A CONTINENTAL PLATE SHOWING EVIDENCE OF DIVERGENT PLATE MOVEMENTS AS OPPOSED TO BEING LOCATED ON A PLATE SHOWING CONVERGENT PLATE MOVEMENTS */

expl /* I am trying to determine if the Gabon Basin is located along a continental margin and in an area involved in divergent (extensional or pull-apart) crustal plate movements, as opposed to being located on a 
continental margin in an area involved in compressional or convergent crustal plate movements. */yes APART no WRONG

space APART desc $/ *$ Evidence of a post-Paleozoic basin */

ques ${ }^{*}$ IS THE GABON BASIN LOCATED ALONG A CONTINENTAL MARGIN SUCH THAT IT MAY EXTEND FROM A COASTAL PLAIN TO AN OCEAN DEEP AND WAS FORMED IN THE POSTPALEOZOIC (TRIASSIC OR YOUNGER) *I

expl /* I am trying to determine if the Gabon Basin, located on a craton margin or an accreted zone of a continental margin coastal area, extends offshore AND may partially overlie oceanic crust AND was formed in post-Paleozoic times. */yes CROSS no WRONG

space CROSS desc /* Evidence of a symmetrical basin in early history of basin */

ques ${ }^{*}$ DOES THE GABON BASIN HAVE A PROFILE OR CROSS SECTION ACROSS THE BASIN AT CONTACT OF SEDIMENTS WITH BASEMENT THAT WAS ESSENTIALLY SYMMETRICAL IN ITS EARLY HISTORY */

expl /*I am trying to determine if the Gabon basin was essentially a symmetrical sag in the early history of the basin located along a continental margin.*/ yes SYYY no WRONG

space SYYY desc $/ *$ Evidence of a symmetrical, irregular basin */

ques $/^{*}$ DOES THE GABON BASIN HAVE AN IRREGULAR PROFILE DUE TO EITHER A SINGLE OR MULTIPLE RIFTED BASEMENT WITH RIFT DIVERGENCE (PARALLEL OR TRANSFORM) PROBABLY DUE TO SEA FLOOR SPREADING, AND WHICH WAS POSSIBLY FOLLOWED BY A LINEAR HALF SAG ORIENTED DOWNDIP AND SEAWARD */

expl /* I am trying to determine if the Gabon Basin has an irregular basement profile due to rifting, and if it lies on a continental margin where rift divergence probably was caused by sea-floor spreading in its early history (possibly in the Jurassic). All of which may have been depressed in a linear half sag oriented downdip and seaward. */yes RIFT no WRONG

space RIFT desc $/ *$ Evidence of a symmetrical, irregular, tilted basin */

ques $/^{*}$ IS THE GABON BASIN A SYMMETRICAL, IRREGULAR SHAPED BASIN THAT PROBABLY HAS BEEN TILTED SEAWARD */

expl /* I am trying to determine if the Gabon Basin has been tilted seaward as opposed to being essentially level or horizontal in position. */ yes TILT no WRONG

space TILT desc $/ *$ Evidence of a multicycle basin */

ques $/ *$ DOES THE GABON BASIN HAVE AT LEAST TWO MAJOR MORPHOLOGIC CYCLES OR SEQUENCES AS OPPOSED TO BEING ONLY A SINGLE CYCLE BASIN */

expl /* I am trying to determine if the Gabon Basin has at least two major morphologic cycles or sequences (two or more), rather than being a single cycle basin. */yes MANY no WRONG

space MANY desc $/ *$ Evidence of at least a two-cycle, Atlantic-type basin */

ques ${ }^{*}$ DO YOU THINK THAT THE GABON BASIN COULD BE A RIFTED PASSIVE MARGIN BASIN, LOCATED IN AN AREA OF PLATE DIVERGENCE, WITH A PARALLEL RIFT SYSTEM OR A TRANSFORM FAULTED SYSTEM, THAT MIGHT BE CLASSIFIED AS A KLEMME CLASS IIIC BASIN */

expl $/ *$ I am trying to determine, with the evidence discussed so far, whether you think that the Gabon Basin could be a Rifted Passive Margin Basin of the Parallel subclass, or the Transform faulted subclass, of the Klemme Class IIIC type basin. */yes RIGHT no WRONG

space RIGHT desc /* Evidence that Gabon Basin is a Klemme Class IIIC basin */

inf $/^{*}$ Congratulations! From the geclogic evidence as described in the first six or seven steps of the Klemme basin classification system you have decided that the Gabon Basin may be classified in the Klemme IIIC Class. If 
you made it this far in answering the questions about the Gabon Basin you should have a good idea of the type of regional geologic information that is needed about a basin in the early stages of classification in the Klemme system. If you wish to continue with the classification of the Gabon Basin, return to the Options Menu and select model 7, IIIC-Rifted Passive Margin Basins for a more detailed description. */

space OUT1 desc $/ *$ Suggestions to user */

$\inf /^{*}$ It may be that you are missing key information about the basic regional geology of the Gabon Basin. I would recommend that you rerun this Introduction model and select a basin on which you have more available geologic information, OR read up on the Gabon Basin and rerun the test-basin option in this model. You might want to strike out on your own and select one of the nine basin models to run for the basin of your choice, OR you might want to just forget the whole thing, call it a day, and go fishing! (Please take me with you.) Good Luck! */

space END desc $/ *$ Suggestions to user * $/$

$\inf /^{*}$ Attention User! To have arrived at this answer you have followed a path of logic in one of two ways. You have made your own basin selection and decided it was (1) either/or a continental cratonic or a cratonaccreted margin basin, but the logic in your answers has taken you to the oceanic basin category, OR (2) you started with the oceanic basin category, but you have answered that your basin is not located on oceanic crust (or is not located primarily on oceanic crust.) Therefore, there would appear to be a major inconsistency in your geologic answers relative to the basin of your choice. I would recommend that you rerun this Introductory model and (1) after rechecking the information on the basin you have selected, reconsider your answers, OR (2) select a different basin to classify, OR (3) select the test basin (the Gabon Basin of Africa) provided in this exercise. Good Luck! */

STOP 


\section{APPENDIX C-2.-TRANSCRIPT OF A TRIAL RUN OF OPTION 1-AN INTRODUCTION AND TUTORIAL MODEL}

\section{WORLD BASIN CLASSIFICATION SYSTEM FOR PETROLEUM RESOURCE APPRAISAL DESIGNED BY BETTY M. MILLER}

This is the first phase of a prototype expert system, called muPETROL, designed by Betty M. Miller, to assist in classifying the sedimentary basins of the world by using the Klemme world basin classification scheme with respect to the petroleum potential of the basin.

In using the program you will be asked to answer questions about the existence of various kinds of evidence. Answers to questions can be "Y," "N," or if you don't know, "D." To quit, enter "Q." In addition to supplying answers, you can request information at any time with the following commands:

? - Print a rephrased version of the question

A - Access data base to assist in answering the question

$S$ - Print a summary at this point in the consultation

$\mathrm{T}$-Let me see muPETROL's partial conclusions

$\mathrm{U}-$ Stop the trace

W-Show answer to a previous question

$B-$ Break the consultation and put me in muLISP

Press RETURN to continue ...

\section{mUPETROL World Basin Classification}

Number Basin

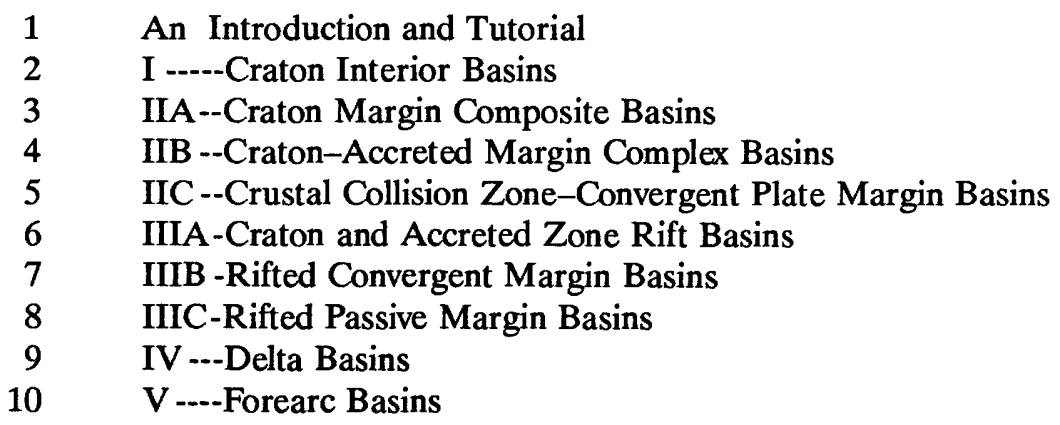

Enter number or $\mathrm{Q}$ to quit: 1

This is an introductory approach to determine how familiar you are with the concepts of classifying the world's sedimentary basins relative to plate tectonics.

1-ARE YOU FAMILIAR WITH THE GEOLOGIC CONCEPTS USED IN SOME OF THE BETTER KNOWN WORLD SEDIMENTARY BASIN CLASSIFICATION SYSTEMS

(Y/N/D/A/S/T/U/W/Q/B/?) : Y

2-ARE YOU FAMILIAR WITH THE BASIC GEOLOGIC CONCEPTS OF THE BALLY-SNELSON WORLD BASIN CLASSIFICATION SYSTEM THAT WAS PUBLISHED IN 1980 BY THE CANADIAN SOCIETY OF PETROLEUM GEOLOGISTS MEMOIR 6

(Y/N/D/A/S/T/U/W/Q/B/?) : Y

3-ARE YOU FAMILIAR WITH THE BASIC GEOLOGIC CONCEPTS FOR THE KINGSTONDISHROON-WILLIAMS WORLD BASIN CLASSIFICATION SYSTEM THAT WAS PUBLISHED IN 1983 (Y/N/D/A/S/T/U/W/Q/B/?) : Y

4-ARE YOU FAMILIAR WITH THE BASIC GEOLOGIC CONCEPTS OF THE KLEMME WORLD BASIN CLASSIFICATION SYSTEM AS RELATED TO PETROLEUM OCCURRENCE

(Y/N/D/A/S /T/U/W/Q/B/?) : Y 
5-ARE YOU FAMILIAR WITH ANY OF THE VARIOUS MAPS SHOWING THE SEDIMENTARY PROVINCES OR BASINS OF THE WORLD AND THE LOCATION OF THE GLOBAL PLATE BOUNDARIES

$(\mathrm{Y} / \mathrm{N} / \mathrm{D} / \mathrm{A} / \mathrm{S} / \mathrm{T} / \mathrm{U} / \mathrm{W} / \mathrm{Q} / \mathrm{B} / ?): \mathrm{Y}$

6-DO YOU HAVE A SEDIMENTARY BASIN IN MIND THAT YOU WOULD LIKE TO USE AS A TEST BASIN THAT WE COULD USE AS AN EXAMPLE FOR AN INTRODUCTORY TRIAL RUN TO ILLUSTRATE THE BASIN CLASSIFICATION TECHNIQUE

(Y/N/D/A/S/T/U/W/Q/B/?) : Y

The following is intended to aid you in the first step to classifying your sedimentary basin.

7-For which of the following do you have any information:

1. Continental Cratonic Basin

2. Continental Craton-Accreted Margin Basin

3. Oceanic (or partly oceanic) Basins

Please enter one or more of the preceding numbers (separated by blanks and terminating with $\mathrm{a}<\mathrm{CR}>2$ )

8-IS YOUR BASIN LOCATED ON AN ACCRETED ZONE NEAR THE MARGIN OF A CONTINENTAL PLATE OR CRATON

(Y/N/D/A/S/T/U/W/Q/B/?) : Y

Congratulations! You have decided that you may have a continental, accreted craton margin basin. The following questions will help you to understand the next steps in the decisionmaking process for this basin classification system.

9-DO YOU KNOW THE TYPE OF PAST PLATE MOVEMENT THAT WAS INVOLVED IN THE AREA OF YOUR BASIN FORMATION (DIVERGENT OR CONVERGENT)

(Y/N/D/A/S/T/U/W/Q/B/?) : Y

10-WAS THE FORMATION OF YOUR CONTINENTAL CRATON-ACCRETED MARGIN BASIN IN AN AREA WHERE THE PAST PLATE MOVEMENT HAS BEEN PRIMARILY DIVERGENT OR EXTENSIONAL, AS OPPOSED TO CONVERGENT (OR COMPRESSIONAL)

(Y/N/D/A/S/T/U/W/Q/B/?) : Y

11-DOES YOUR BASIN HAVE A SYMMETRICAL PROFILE OR CROSS SECTION ACROSS THE BASIN AT THE CONTACT OF THE SEDIMENTS WITH THE BASEMENT

(Y/N/D/A/S/T/U/W/Q/B/?) : Y

12-DOES YOUR BASIN HAVE AN IRREGULAR OR FAULTED SEDIMENT-BASEMENT CONTACT WITH RIFT FAULTING, AS OPPOSED TO A REGULAR (SMOOTH) SEDIMENT-BASEMENT CONTACT WITH LITTLE OR NO FAULTING

(Y/N/D/A/S/T/U/W/Q/B/?) : Y

Based on your responses, my evaluation is as follows:

1. I think you have sampled enough of the questions to become familiar with the type of geologic information that is requested as a start to classifying divergent, irregular, symmetrical continental accreted craton margin basins. You have a good possibility of your basin being in the Klemme IIB Class or the IIIA Class. I would recommend that you go back to the Options Menu and select either the model for IIB-Craton-Accreted Margin Complex Basins or the model for IIIA-Craton and Accreted Zone Rift Basins for a more detailed description. Have fun. Good Luck!

You have established:

2. Familiar with world sedimentary basin classifications

3. Familiar with the Bally-Snelson world basin classification system

4. Familiar with the Kingston et al. world basin classification system

5. Familiar with the Klemme world basin classification system

6. Familiar with the map showing the sedimentary provinces of the world and the tectonic plate boundaries

7. Identification of a test basin

8. Continental Craton-Accreted Margin Basin

9. Evidence of a continental basin located on an accreted craton margin 
10. Evidence of a continental craton-accreted margin basin

11. Evidence of a divergent, continental accreted craton margin basin

12. Evidence of a symmetrical, divergent continental accreted craton margin basin

13. Evidence of an irregular, symmetrical basin

Do you wish to consider another basin or another area $(\mathrm{Y} / \mathrm{N} / \mathrm{Q} / \mathrm{B} /$ ? $): \mathrm{Y}$

\section{mUPETROL World Basin Classification}

\begin{tabular}{cl} 
Number & \multicolumn{1}{c}{ Basin } \\
1 & An Introduction and Tutorial \\
2 & I -----Craton Interior Basins \\
3 & IIA--Craton Margin Composite Basins \\
4 & IIB --Craton-Accreted Margin Complex Basins \\
5 & IIC --Crustal Collision Zone-Convergent Plate Margin Basins \\
6 & IIIA-Craton and Accreted Zone Rift Basins \\
7 & IIIB -Rifted Convergent Margin Basins \\
8 & IIIC-Rifted Passive Margin Basins \\
9 & IV ---Delta Basins \\
10 & V ----Forearc Basins
\end{tabular}

Enter number or $\mathrm{Q}$ to quit: 1

This is an introductory approach to determine how familiar you are with the concepts of classifying the world's sedimentary basins relative to plate tectonics.

1-ARE YOU FAMILIAR WITH THE GEOLOGIC CONCEPTS USED IN SOME OF THE BETTER KNOWN WORLD SEDIMENTARY BASIN CLASSIFICATION SYSTEMS

$(\mathrm{Y} / \mathrm{N} / \mathrm{D} / \mathrm{A} / \mathrm{S} / \mathrm{T} / \mathrm{U} / \mathrm{W} / \mathrm{Q} / \mathrm{B} /$ ? $): \mathrm{Y}$

2-ARE YOU FAMILIAR WITH THE BASIC GEOLOGIC CONCEPTS OF THE BALLY-SNELSON WORLD BASIN CLASSIFICATION SYSTEM THAT WAS PUBLISHED IN 1980 BY THE CANADIAN SOCIETY OF PETROLEUM GEOLOGISTS MEMOIR 6

(Y/N/D/A/S/T/U/W/Q/B/?) : Y

3-ARE YOU FAMILIAR WITH THE BASIC GEOLOGIC CONCEPTS FOR THE KINGSTONDISHROON-WILLIAMS WORLD BASIN CLASSIFICATION SYSTEM THAT WAS PUBLISHED IN 1983 (Y/N/D/A/S/T/U/W/Q/B/?) : Y

4-ARE YOU FAMILIAR WITH THE BASIC GEOLOGIC CONCEPTS OF THE KLEMME WORLD BASIN CLASSIFICATION SYSTEM AS RELATED TO PETROLEUM OCCURRENCE (Y/N/D/A/S/T/U/W/Q/B/?) : Y

5-ARE YOU FAMILIAR WITH ANY OF THE VARIOUS MAPS SHOWING THE SEDIMENTARY PROVINCES OR BASINS OF THE WORLD AND THE LOCATION OF THE GLOBAL PLATE BOUNDARIES

(Y/N/D/A/S/T/U/W/Q/B/?) : Y

6-DO YOU HAVE A SEDIMENTARY BASIN IN MIND THAT YOU WOULD LIKE TO USE AS A TEST BASIN THAT WE COULD USE AS AN EXAMPLE FOR AN INTRODUCTORY TRIAL RUN TO ILLUSTRATE THE BASIN CLASSIFICATION TECHNIQUE

$(\mathrm{Y} / \mathrm{N} / \mathrm{D} / \mathrm{A} / \mathrm{S} / \mathrm{T} / \mathrm{U} / \mathrm{W} / \mathrm{Q} / \mathrm{B} / ?): \mathrm{N}$

7-THE TEST BASIN PROVIDED IN THIS EXERCISE IS THE GABON BASIN ON THE WEST COAST OF AFRICA. WOULD YOU LIKE TO FOLLOW THE INITIAL STEPS IN CLASSIFYING THIS BASIN

(Y/N/D/A/S/T/U/W/Q/B/?) : Y

The Gabon Basin is located along the western coast of central Africa, in the country of Gabon. It is basically a continental margin basin bordering the eastern Atlantic Ocean. 
8-IS THE GABON BASIN LOCATED PRIMARILY ON A CONTINENTAL CRUSTAL PLATE AS OPPOSED TO BEING LOCATED ON AN OCEANIC PLATE

$\mathrm{Y} / \mathrm{N} / \mathrm{D} / \mathrm{A} / \mathrm{S} / \mathrm{T} / \mathrm{U} / \mathrm{W} / \mathrm{Q} / \mathrm{B} /$ ?) : Y

9-IS THE GABON BASIN BORDERING ON A PRESENT-DAY ATLANTIC CONTINENTAL MARGIN AS OPPOSED TO A COASTAL AREA BORDERING THE CIRCUM-PACIFIC OCEAN

(Y/N/D/A/S/T/U/W/Q/B/?) : Y

10-IS THE GABON BASIN LOCATED ON A CONTINENTAL PLATE SHOWING EVIDENCE OF DIVERGENT PLATE MOVEMENTS AS OPPOSED TO BEING LOCATED ON A PLATE SHOWING CONVERGENT PLATE MOVEMENTS

(Y/N/D/A/S/T/U/W/Q/B/?) : Y

11-IS THE GABON BASIN LOCATED ALONG A CONTINENTAL MARGIN SUCH THAT IT MAY EXTEND FROM A COASTAL PLAIN TO AN OCEAN DEEP AND WAS FORMED IN THE POST-PALEOZOIC (TRIASSIC OR YOUNGER)

$(\mathrm{Y} / \mathrm{N} / \mathrm{D} / \mathrm{A} / \mathrm{S} / \mathrm{T} / \mathrm{U} / \mathrm{W} / \mathrm{Q} / \mathrm{B} / ?): \mathrm{Y}$

12-DOES THE GABON BASIN HAVE A PROFILE OR CROSS SECTION ACROSS THE BASIN AT CONTACT OF SEDIMENTS WITH BASEMENT THAT WAS ESSENTIALLY SYMMETRICAL IN ITS EARLY HISTORY

(Y/N/D/A/S/T/U/W/Q/B/?) : Y

13-DOES THE GABON BASIN HAVE AN IRREGULAR PROFILE DUE TO EITHER A SINGLE OR MULTIPLE RIFTED BASEMENT WITH RIFT DIVERGENCE (PARALLEL OR TRANSFORM) PROBABLY DUE TO SEA FLOOR SPREADING, AND WHICH WAS POSSIBLY FOLLOWED BY A LINEAR HALF SAG ORIENTED DOWNDIP AND SEAWARD

(Y/N/D/A/S/T/U/W/Q/B/?) : Y

14-IS THE GABON BASIN A SYMMETRICAL, IRREGULAR SHAPED BASIN THAT PROBABLY HAS BEEN TILTED SEAWARD

(Y/N/D/A/S/T/U/W/Q/B/?) : Y

15-DOES THE GABON BASIN HAVE AT LEAST TWO MAJOR MORPHOLOGIC CYCLES OR SEQUENCES AS OPPOSED TO BEING ONLY A SINGLE CYCLE BASIN

(Y/N/D/A/S/T/U/W/Q/B/?) : Y

16-DO YOU THINK THAT THE GABON BASIN COULD BE A RIFTED PASSIVE MARGIN BASIN, LOCATED IN AN AREA OF PLATE DIVERGENCE, WITH A PARALLEL RIFT SYSTEM OR A TRANSFORM FAULTED SYSTEM, THAT MIGHT BE CLASSIFIED AS A KLEMME CLASS IIIC BASIN (Y/N/D/A/S/T/U/W/Q/B/?) : Y

Based on your responses, my evaluation is as follows:

1. Congratulations! From the geologic evidence as described in the first six or seven steps of the Klemme basin classification system you have decided that the Gabon Basin may be classified in the Klemme IIIC Class. If you made it this far in answering the questions about the Gabon Basin you should have a good idea of the type of regional geologic information that ${ }^{-}$is needed about a basin in the early stages of classification in the Klemme system. If you wish to continue with the classification of the Gabon Basin, return to the Options Menu and select model 7, IIIC-Rifted Passive Margin Basins for a more detailed description.

You have established:

2. Familiar with world sedimentary basin classifications

3. Familiar with the Bally-Snelson world basin classification system

4. Familiar with the Kingston et al. world basin classification system

5. Familiar with the Klemme world basin classification system

6. Familiar with the map showing the sedimentary provinces of the world and the tectonic plate boundaries

7. No identification of a test basin

8. Favorable assumption for running test basin as provided

9. Evidence of basin location

10. Evidence of an Atlantic continental margin basin

11. Evidence of a divergent basin

12. Evidence of a post-Paleozoic basin

13. Evidence of a symmetrical basin in early history of basin 
14. Evidence of a symmetrical, irregular basin

15. Evidence of a symmetrical, irregular, tilted basin

16. Evidence of a multicycle basin

17. Evidence of at least a two-cycle, Atlantic-type basin

Do you wish to consider another basin or another area $(\mathrm{Y} / \mathrm{N} / \mathrm{Q} / \mathrm{B} /$ ? $): \mathrm{N}$

STOP 
APPENDIX D. -INFERENCE NET AND LISTING FOR CLASS I-CRATON INTERIOR BASINS (MODEL 1), FILE NAME CRATON

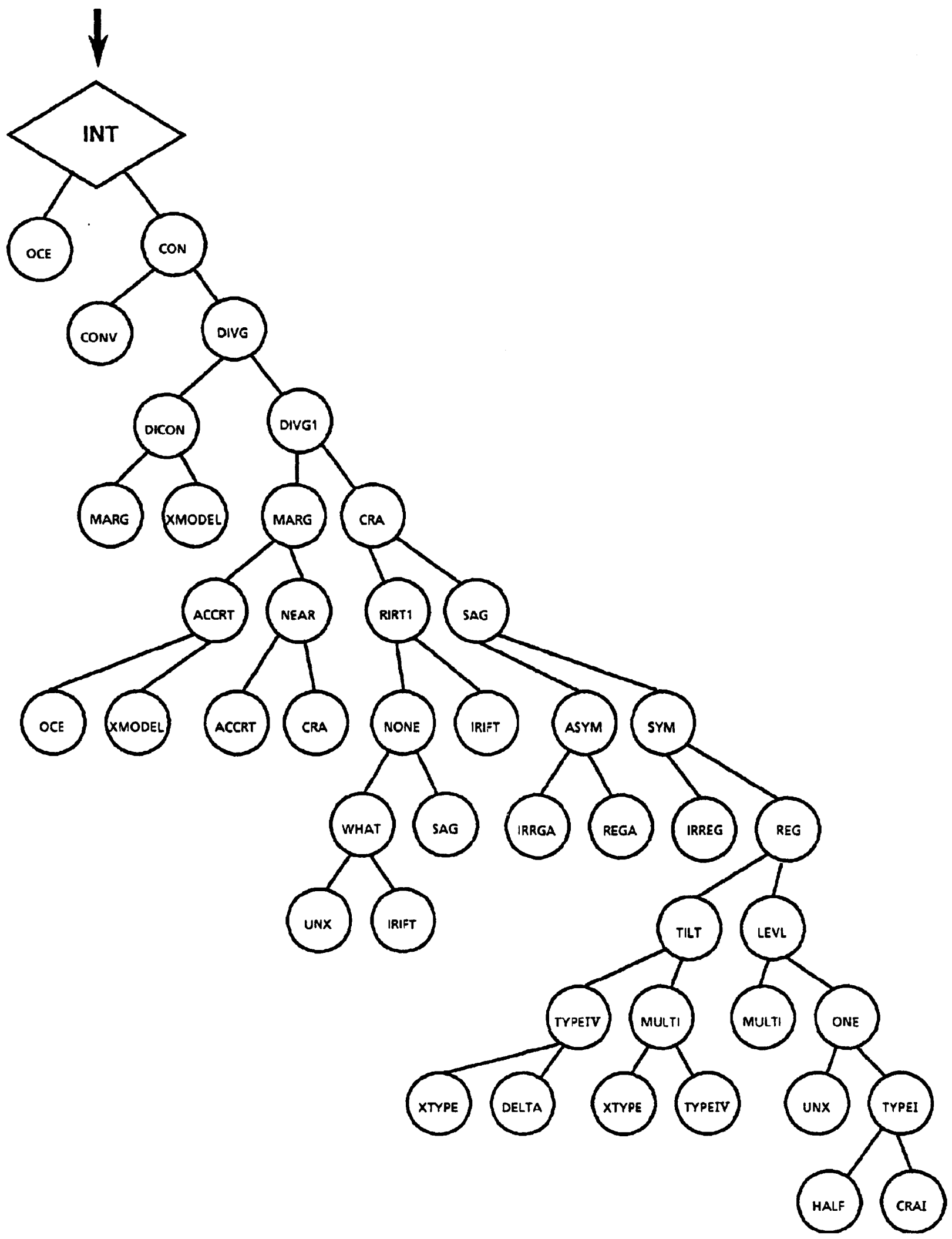

Inference net for Class I-Craton Interior Basins (model 1), file name CRATON.

Appendix D

29 
model CRATON

topspace INT

space INT desc $/ *$ Evidence that the prospective basin is located on continental rather than oceanic crust */

announce $l^{*}$ The following is intended to aid in the classification of interior cratonic basins */

ques ${ }^{*}$ IS THE BASIN LOCATED ON INTERIOR CONTINENTAL OR MOSTLY CONTINENTAL CRUST *I

expl $/^{*}$ I am trying to determine the basin's position relative to the Earth's major crustal zones, i.e. interior continental versus oceanic crust */ yes CON no OCE

space CON desc /* Evidence of divergent past plate movement involved during the early cycle of basin formation rather than convergent plate movement $* /$

ques $/ *$ IS THE BASIN LOCATED IN AN AREA OF PRIMARILY DIVERGENT (EXTENSIONAL) CRUSTAL PLATE MOVEMENT IN AREAS OF PRECAMBRIAN ACCRETION WHICH REMAINED ESSENTIALLY STABLE DURING THE PHANEROZOIC */

expl /* I am trying to determine if the basin's position is on a divergent or extensional continental crust rather than a convergent or compressional continental crust */yes DIVG no CONV

space DIVG desc $/^{*}$ Evidence of a simple divergent basin rather than a basin that has been modified by later convergent plate movements */

ques ${ }^{*}$ IS YOUR BASIN A SIMPLE DIVERGENT BASIN AS OPPOSED TO ONE THAT HAS BEEN MODIFIED OVER GEOLOGIC TIME BY SUBSEQUENT CONVERGENT PLATE MOVEMENTS */

expl $/^{*}$ Having established that you have a divergent basin I am trying now to determine if it may have been modified later by convergent plate movements */ yes DIVG1 no DICON

space DIVG1 desc $/ *$ Evidence of a cratonic interior basin */

ques ${ }^{*}$ DOES THE BASIN OCCUR IN THE INTERIOR OF A CONTINENTAL CRATONIC MASS RATHER THAN NEAR THE CRATON MARGINS */

expl /* I am trying to determine if the basin occurs entirely within the old cratonic interior near exposed Precambrian shield areas of a crustal plate, rather than near the margins of the craton */ yes CRA no MARG

space MARG desc $/ *$ Evidence of a continental margin basin */

ques /* DO YOU HAVE A SIMPLE CRATONIC BASIN OF THE SAG TYPE LOCATED NEAR THE

EDGE OF THE CRATON AS OPPOSED TO A BASIN ON A MARGINAL ACCRETED ZONE */

expl $/^{*}$ I am trying to distinguish between a fairly simple cratonic basin located near the craton margin rather than a more complex basin located along a younger accreted continental margin */ yes NEAR no ACCRT

space NEAR desc $/ *$ Evidence of a nonparallel, near-margin cratonic basin */

ques $/ *$ IS THE AXIS OF YOUR NEAR-MARGIN CRATONIC BASIN AT A SIGNIFICANT ANGLE TO

THE MARGIN OF THE CRATON AS OPPOSED TO A BASIN WHOSE AXIS IS ESSENTIALLY PARAL-

LEL TO THE MARGIN OF THE CRATON */

expl $/^{*}$ I am trying to distinguish between a simple cratonic sag basin located near the margins of the old craton and essentially at an angle to the craton edge, as opposed to a more complex craton marginal basin whose axis lies essentially parallel to the craton margin, and probably on a younger accreted margin */yes CRA no ACCRT

space CRA desc $/^{*}$ Evidence that the basement profile of a basin is a simple sag rather than a rifted and fractured basement */

ques $/ *$ DOES THE BASIN OCCUR AS A FAIRLY SHALLOW SAG ON OR WITHIN THE CRATON WITH MINOR OR NO FAULTING */

expl $/^{*}$ I am trying to determine if the basin simply sags with minor or no faulting, as opposed to the basement of the basin being fractured with vertical horst and graben faulting and subsidence as the dominant features */ yes 
space RIFT1 desc /* Evidence of a simple cratonic interior basin developed in a fractured or rift zone */ ques ${ }^{*}$ IS THIS BASIN AN INTERIOR FRACTURED BASIN WITH VERTICAL HORST AND GRABEN FAULTING AND SUBSIDENCE AS THE DOMINANT BASIN FEATURES */

$\operatorname{expl} /^{*}$ I am trying to determine whether this interior cratonic basin has a faulted or fractured basement rather than a simple sag basement with very little faulting */yes IRIFT no NONE

space SAG desc $/ *$ Evidence of a simple cratonic interior basin showing a symmetrical basement profile */

announce $/ *$ Congratulations! You have identified a favorable geologic setting for the occurrence of petroleum resources in a Craton Interior Basin. The following questions are intended to aid in evaluating your basin more fully */

ques $/ *$ DOES THE CONTACT OF THE SEDIMENTS WITH THE BASEMENT IN THIS INTERIOR BASIN SHOW A SYMMETRICAL BASEMENT PROFILE RATHER THAN AN ASYMMETRICAL BASEMENT PROFILE */

expl /* I am trying to determine whether the simple interior cratonic basin has a symmetrical basement profile as opposed to an asymmetrical basement profile */ yes SYM no ASYM

space IRIFT desc $/ *$ Evidence of a fractured or rifted interior cratonic basin */

inf $/^{*}$ Congratulations! You have identified a favorable geologic setting for the occurrence of petroleum resources in a craton fractured interior basin. However, you may have a more complex basin of the craton-fracturedinterior type which is better described as a Class IIB (model 3) or IIIA (model 5) basin. I would recommend that you check the descriptions for these two basin models. $*$ /

space SYM desc /* Evidence of a regular basement profile */

ques $/ *$ DOES THIS BASIN HAVE A FAIRLY REGULAR OR SMOOTH BASEMENT PROFILE WITH ONLY MINOR OR NO FAULTING */

expl /* I am trying to determine whether this basin has a regular basin profile, as opposed to an irregular profile due to faulting or rifting */ yes REG no IRREG

space ASYM desc $/ *$ Evidence of a regular asymmetrical basin */

ques $/ *$ DOES THIS BASIN HAVE A FAIRLY REGULAR OR SMOOTH BASEMENT PROFILE WITH ONLY MINOR OR NO FAULTING */

expl $/^{*}$ I am trying to determine whether this basin has a regular basement profile, as opposed to an irregular profile due to faulting or rifting */ yes REGA no IRRGA

space IRREG desc /* Evidence of an irregular symmetrical cratonic basin */

inf $/^{*}$ It would appear that you have a symmetrical cratonic basin with an irregular basement profile. This type of basin is more likely to be classified as a Klemme Class IIB basin (model 3) or a Class IIIA basin (model 5). I would recommend that you check these other basin models. */

space REGA desc $/ *$ Evidence of an asymmetrical regular basin */

inf $l^{*}$ It would appear that you have a cratonic asymmetrically shaped basin with a regular basement profile. This type of basin is more likely to be classified as a Class IIA (model 2) or a Class IIC (model 4) basin. There is also some possibility of it being a Class IV (model 8) basin. I would recommend that you check these other basin models. $* /$

space IRRGA desc $/ *$ Evidence of an asymmetrical irregular basin */

inf $l^{*}$ It would appear that you have a cratonic asymmetrically shaped basin with an irregular basement profile. This type of basin is more likely to be classified as a Class IIA (model 2), or Class IIC (model 4), or Class IIIC (model 7) basin. There is also some possibility of it being a Class IV (model 8) basin. I would recommend that 
you check these other basin models. */

space REG desc $/ *$ Evidence of a horizontal basin with no seaward tilting */

ques $/ *$ IS YOUR BASIN ESSENTIALLY HORIZONTAL OR LEVEL WITH NO SEAWARD TILTING */

expl /* I am trying to determine whether the basin has been fairly stable with no tilting due to subsidence or structural deformation */ yes LEVL no TILT

space LEVL desc /* Evidence of a simple one-cycle (Paleozoic) cratonic basin */

ques $/ *$ DOES YOUR BASIN SHOW EVIDENCE OF ONLY A SINGLE CYCLE OR SEQUENCE OF DEPOSITIONAL OR TECTONIC EVENTS AND THE AGE OF SEDIMENTS IS GENERALLY PALEOZOIC (LOCALLY UPPER PROTEROZOIC AND PALEOZOIC) ONLAPPING PRECAMBRIAN BASEMENT */

expl /* I am trying to establish whether your basin is a simple sag, one-cycle cratonic interior basin as opposed to a more complexly modified cratonic marginal basin with multiple depositional cycles or sequences */ yes ONE no MULTI

space TILT desc $/ *$ Evidence of a tilted, marginal, multicycle, cratonic basin */

ques $/ *$ DOES YOUR BASIN SHOW EVIDENCE OF MORE THAN ONE CYCLE OR SEQUENCE OF DEPOSITIONAL AND TECTONIC EVENTS AND THE SEDIMENTS RANGE IN AGE FROM THE PALEOZOIC INTO THE MESOZOIC AND POSSIBLY EVEN INTO THE TERTIARY *

expl /* I am trying to determine if you have a basin, possibly located at or near the craton margin, that has been tilted seaward and has more than one depositional or tectonic cycle */ yes MULTI no TYPEIV

space ONE desc $/ *$ Evidence of a single-cycle, Klemme Type I, Craton Interior basin */

ques ${ }^{*}$ DO YOU THINK YOU HAVE A BASIN OF THE KLEMME TYPE I CLASSIFICATION, A SIMPLE CRATON INTERIOR BASIN WITH A SINGLE CYCLE OF DEPOSITION OR TECTONIC HISTORY *I

expl /* I am trying to determine whether you have a simple interior cratonic basin that has experienced a single depositional or tectonic type history. Analogs for this type of basin might be the Denver basin, Michigan basin, Illinois basin, or Williston basin */ yes TYPEI no UNX

space MULTI desc/* Evidence of a multicycle cratonic basin with possibly a delta depocenter of Tertiary age */

ques $/ *$ DO YOU THINK YOU HAVE A CRATONIC MARGINAL BASIN THAT HAS BEEN TILTED SEAWARD AND IN WHICH ADDITIONAL DEPOSITIONAL CYCLES HAVE TAKEN PLACE, POSSIBLY EVEN A DELTA DEPOCENTER OF TERTIARY AGE */

expl $/ *$ I am trying to determine if you have a cratonic basin, possibly located along a marginal sag or rift that has experienced more than one depositional and tectonic cycle and that could possibly have a delta depocenter of Tertiary age */ yes TYPEIV no XTYPE

space TYPEI desc /* Classification of a Klemme Class I, Craton Interior Basin *

announce $/ *$ Congratulations! You have successfully classified a Klemme Class I Craton Interior Basin. */

ques ${ }^{*}$ DO YOU HAVE ONE OF THE FOLLOWING BASINS OR A SIMILAR BASIN: CINCINNATI ARCH, DENVER, FOXE, HUDSON BAY, ILLINOIS, JONES-LANCASTER, KNUD RASMUSSEN, LAKE SUPERIOR, SALINA-FOREST CITY, MICHIGAN, UNGAVA BAY, VICTORIA STRAIT, VOLTA, WILLISTON, WOLLASTON, LOWER, MIDDLE, AND UPPER AMAZON, CHACO, ORD, PARANA, PARNAIBA, SAO FRANCISCO, CHAD, ETOSHA, ILLIZI, KUFRA, MURZUK, OKAVANGO DELTA, TAOUDENNI, BARENTS WEST, GULF OF CARPENTARIA, DALY RIVER, GEORGINA, WISO, BALTIC, BARENTS EAST, MEZEN, MOSCOW, OLENEK, TUNGUSKA, DUFEK, MARIE BYRD, AND WILKES */

expl $/ *$ I am trying to determine if your basin is one of these specific basins or a basin, similar geologically to these basins, that has been classified by Klemme as a Class I basin. */yes CRAI no HALF 
space CRAI desc $/ *$ Successful description of a Class I-Craton Interior Basin */

inf $l^{*}$ Congratulations! You have identified your basin as a Class I Craton Interior basin. You have also selected one of the basins from the list of analog basins that have been classified by Klemme as Class I basins. You are ready to make a detailed analysis of your basin. */

space HALF desc $/ *$ Partial success in describing a Class I basin */

inf $/^{*}$ Partial congratulations are in order. You have identified your basin as a Class I basin. However, you did not select any one of the basins in the analog list as classified by Klemme as Class I basins. You may be missing some crucial geologic information on your basin and need to recheck and rerun this model, OR you may have a basin that is better classified as a Class IIA, IIB, or IIIA basin. You may wish to run models 2,3 or $5 . * /$

space TYPEIV desc $/ *$ Evidence of a Klemme Type IV Delta Basin */

ques $/ *$ DO YOU THINK YOU HAVE A BASIN THAT HAS A DELTA DEPOCENTER OF POSSIBLY TERTIARY AGE * $/$

expl /* If you have a multicycle craton margin basin that has a delta depocenter of Tertiary age you probably have a Klemme type IV basin. If it is not a deltaic basin then you probably have a more complex basin of a different type. */yes DELTA no XTYPE

space DELTA desc /* Evidence of a Delta Basin within a cratonic margin basin */

inf $/ *$ Congratulations! You have identified a favorable geologic setting for petroleum potential and have a basin that is a cratonic basin, probably a cratonic margin basin, that has been the site for the later development of a delta depocenter. This is one form of a Klemme Type IV Delta Basin, possibly a Mackenzie or Niger type basin. For additional information on Delta Depocenter basins check model 9 in this basin classification system. */

space XTYPE desc /* Possible evidence of multicycle basins other than craton or cratonic delta depocenters */

inf $/^{*}$ If you have a multicycle basin that does not meet the criteria for the Craton Class I basin or the Delta Class IV basin, you probably have a basin that would be classified as one of the other basin models such as Class IIA or IIB (models 3 and 4) in this world basin classification system. */

space NONE desc $/ *$ Favorable assumption of an interior sag basin rather than a rifted interior basin */ announce $/^{*}$ Insufficient evidence at present that indicates whether an interior craton basin may have a basement that is classified as an interior rift or fracture basin */ ques $l^{*}$ WOULD YOU LIKE TO ASSUME THAT YOU HAVE AN INTERIOR SAG BASIN RATHER THAN A RIFTED INTERIOR BASIN */

expl $/ *$ If you wish to assume that it is a simple interior sag basin, then we can continue with the analysis of your basin */ yes SAG no WHAT

space WHAT desc $/ *$ Favorable assumption of a rifted interior basin */

ques $/ *$ WOULD YOU LIKE TO ASSUME THAT YOU HAVE AN INTERIOR RIFTED BASIN */

expl $/^{*}$ If you wish to assume that it is an interior rifted basin, then we can continue with recommendations for describing this basin class */ yes IRIFT no UNX

space UNX desc $/^{*}$ Insufficient evidence for a simple interior cratonic sag basin */

inf $/^{*}$ Insufficient evidence at present that would indicate a simple interior cratonic sag basin of the Klemme Class I. You may wish to run through the other basin classes for classification or you may want to start with basin class IIB or IIIA, models 3 and 5 in this basin classification system. */

space ACCRT desc $/^{*}$ Evidence that basin is located on accreted crustal zones near old craton margins and not on an old craton *I

ques $/^{*}$ IS YOUR BASIN LOCATED ON ACCRETED CRUSTAL ZONES NEAR THE MARGINS OF AN OLD CRATON, AND NOT ON AN OLD CRATON */ 
expl $/^{*}$ If your basin is not located within the interior or near-margin of a craton, then it must be located on some form of accreted crustal zone, as opposed to being located on oceanic crust */ yes XMODEL no OCE

space XMODEL desc /* Evidence that basin is described as a noncratonic or accreted zone basin */

inf $/^{*}$ Your basin is a noncratonic or accreted zone basin and is described for other basin models, probably Class II and Class III basins, in this world basin classification system. */

space OCE desc $/ *$ Evidence that basins are located on oceanic or partially on oceanic crust */

inf $/^{*}$ Your basin is an oceanic basin located on oceanic crust or partially on oceanic crust. You should check the Class IV and V basins (models 8 and 9 ) in this world basin system. */

space DICON desc $/^{*}$ Evidence that the basin was originally located on a divergent plate, and modified later by convergent movements either within or near the original basin location */

ques $/ *$ DO YOU HAVE A BASIN THAT WAS LOCATED ON A DIVERGENT CRATON PLATE THAT HAS BEEN TECTONICALLY MODIFIED BY LATER CONVERGENT PLATE MOVEMENTS *

$\operatorname{expl} / *$ I am trying to determine if you have a basin that originally would be classified as a divergent basin but has subsequently been modified by younger convergent type plate movements */ yes XMODEL no MARG

space CONV desc /* Description of basins located on converging or compressional plates */

inf $/^{*}$ There is evidence that your basin is located on the margins or nearby interiors of two or more plates converging toward one another. Check basin Class IIC and Class IIIB (models 4 and 6) in this world basin classification system. $* /$

STOP 
APPENDIX E. -INFERENCE NET AND LISTING FOR CLASS IIA-CRATON MARGIN COMPOSITE BASINS (MODEL 2), FILE NAME IIAMARG

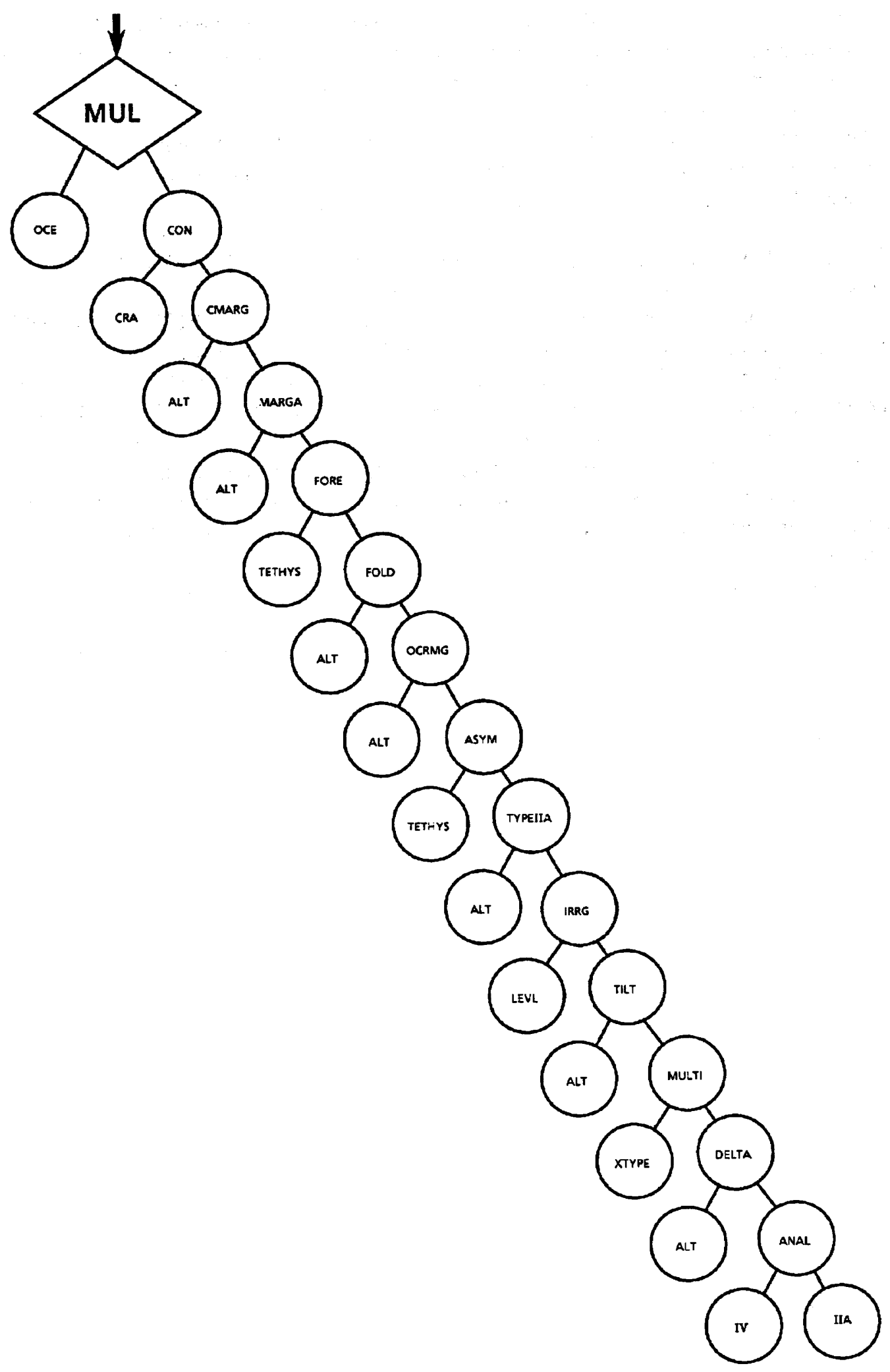

Inference net for Class IIA-Craton Margin Composite Basins (model 2), file name IIAMARG.

Appendix E

35 
model IIAMARG

topspace MUL

space MUL desc $/ *$ Evidence that the prospective basin is located on continental rather than oceanic crust */ ques $/^{*}$ IS THE BASIN LOCATED PRIMARILY ON CONTINENTAL CRUST AS OPPOSED TO BEING LOCATED ON MOSTLY OCEANIC CRUST */

expl /* I am trying to determine the position of the basin relative to the major crustal zones, continental rather than oceanic crust. */ yes CON no OCE

announce $/^{*}$ The following is intended to aid in the classification of Continental Multicycle Basins. */

space OCE desc $/^{*}$ Evidence that the basin is located on oceanic crust or partially on oceanic crust */

inf $/ *$ Your basin is an oceanic basin located on oceanic crust or partially on oceanic crust. You will need to check the other basin models in the world basin classification system, particularly Class V, model 9. */

space CON desc $/^{*}$ Evidence that the basin is a continental multicycle basin located near an old cratonic margin and of a composite nature */

ques $/^{*}$ IS YOUR BASIN LOCATED NEAR THE MARGINS OF AN OLD CRATONIC SHIELD RATHER THAN AN INTERIOR CRATONIC BASIN */

expl /* If your basin is an interior sag or interior rift basin located on an old craton, it is not included in this model and your answer should be No. */ yes CMARG no CRA

space CRA desc $/ *$ Evidence of an interior craton basin */

inf $/^{*}$ The presence of an interior sag or interior rift basin is described under Class I (model 1) and should be checked for classification under that model in this world basin classification system */

space CMARG desc /* Evidence of a continental multicycle basin located along an old cratonic margin */

ques /* IS YOUR BASIN LOCATED ALONG THE CRATON MARGIN OR PERICRATON IN WHAT

WAS ONCE AN OLD CRATONIC MARGIN SAG OR MARGIN RIFT BASIN AS OPPOSED TO A YOUNGER ACCRETED MARGIN */

expl /* I am trying to determine whether you have a basin which was an old continental margin basin which has been converted into an interior basin by the subsequent formation of a foldbelt on the seaward side of the basin. */yes MARGA no ALT

space ALT desc $/^{*}$ Evidence of other marginal basins not included in this model */

inf $/ *$ If you have a marginal basin that was formed along an accreted margin or along present-day continental margins, your basin would be included in other basin classes. You should check models 3, 4, 6, 7, or 8 in this world basin classification system. Good luck! */

space MARGA desc $/ *$ Evidence of a foredeep basin */

ques $/ *$ IS THERE EVIDENCE THAT YOUR BASIN HAS FOREDEEP SEDIMENTS THAT WERE DEPOSITED OFF THE GENTLY DIPPING CONTINENTAL PLATFORM INTO AN OLD OCEAN BASIN */

expl /* I am trying to determine whether you have an old divergent continental margin basin that has been converted to an interior basin by a subsequent orogenically derived foredeep and foldbelt due to convergent movements from the seaward side. */yes FORE no ALT

space FORE desc $/^{*}$ Evidence of a foldbelt or events of episodic wrenching which modified an old cratonic margin basin */

ques $/ *$ IS THERE EVIDENCE THAT THE FOREDEEP SEDIMENTS IN THE BASIN HAVE BEEN OROGENICALLY MOVED POSSIBLY AS AN ACCRETED ZONE ONTO AND OVER THE CRATON EITHER AS A FOLDBELT OR THROUGH EPISODIC WRENCHING */

expl $/^{*}$ I am trying to determine if you have a basin originally of a divergent origin which was later modified 
by convergent plate movements resulting in an orogenically derived foredeep and/or foldbelt, as opposed to a Tethyan basin. If you have a Tethyan basin, answer No. */yes FOLD no TETHYS

space TETHYS desc /* Evidence of a Tethyan basin */

inf $/^{*}$ If you have a divergent basin that was later modified by convergent plate movements and it is located in the old Tethyan seaway, you probably have one of the variations of the Class IIC basins. You should check basin model 4. $*$ /

space FOLD desc $/^{*}$ Evidence of a marginal sag-cycle converted into an interior basin by the subsequent formation of a foldbelt on the seaward side */

ques $/^{*}$ DO YOU HAVE AN OLD INTERIOR MARGIN BASIN THAT HAS BEEN TRANSFORMED INTO AN INTERIOR SAG BASIN BY A FOLDBELT OR SOME FORM OF EPISODIC WRENCHING */

expl $/^{*}$ I am trying to determine if your old craton margin sag basin or cycle was transformed into an interior sag basin to differentiate it from cycles deposited as interior cratonic sags and also from modern marginal sag basins. */yes OCRMG no ALT

space OCRMG desc /* Evidence of a classic asymmetrical basin */

ques $l^{*}$ DO YOU HAVE WHAT WOULD APPEAR TO BE AN OLD MARGINAL INTERIOR SAG BASIN WITH THE CLASSIC ASYMMETRICAL PROFILE OF A FOREDEEP AND FOLDBELT */

expl /* I am trying to distinguish between an old craton margin composite basin and a craton-accreted margin complex basin both originating as divergent craton basins. */yes ASYM no ALT

space ASYM desc $/^{*}$ Evidence that the basin is located outside of the Tethys zone */

ques ${ }^{*}$ IS YOUR BASIN LOCATED OUTSIDE OF THE TETHYS ZONE RATHER THAN WITHIN THE COLLISION ZONE OF THE TETHYS *

expl /* This is to distinguish between asymmetrical basins located outside the Tethys as opposed to those located within the Tethys. Check on the world basin map of Klemme to determine location of Tethys and basins within Tethys. */yes TYPEIIA no TETHYS

space TYPEIIA desc $/^{*}$ Evidence of a classic asymmetrical basin of a composite nature that lies along an old craton margin *I

announce $/ *$ Congratulations! You have identified a favorable geologic setting for petroleum resources within a probable craton margin composite basin that was of a divergent nature and later modified by convergent movements. This basin shows evidence of a foredeep and a foldbelt with a classic asymmetrical basement profile. It is classified by Klemme as a class IIA Craton Margin Composite Basin. The following questions are intended to aid in evaluating this possibility more fully. $*$ I

ques /* DOES YOUR ASYMMETRICAL CRATON MARGIN BASIN HAVE AN IRREGULAR BASEMENT PROFILE */

expl /* I am trying to determine if the basement of the basin is fractured with vertical horst and graben faulting and subsidence rather than a simple sag basin with minor or no faulting in the basement. */ yes IRRG no ALT

space IRRG desc $/ *$ Evidence of an irregular asymmetrical tilted basin */

ques $/ *$ DO YOU HAVE AN IRREGULAR ASYMMETRICAL BASIN THAT IS TILTED SEAWARD */

expl $/^{*}$ I am trying to determine if the asymmetrical basin with an irregular basement profile has been tilted seaward due to subsidence or faulting. */ yes TILT no LEVL

space LEVL desc $/ *$ Evidence of a nontilted or level basin */

inf $/^{*}$ You have an asymmetrical basin of the Class IIA Craton Margin Composite basin that appears to have been slightly modified by convergent movements, OR modified very little by convergent movements that resulted in little or no tilting of the basin. You may wish to check Class IIB, model 3, in this world basin classification system. */ 
space TILT desc $/^{*}$ Evidence of a craton margin basin that has experienced rapid subsidence and oceanward tilting with more than one cycle or sequence of depositional and tectonic events */

ques $/ *$ DOES YOUR BASIN SHOW EVIDENCE OF MORE THAN ONE CYCLE OR SEQUENCE OF DEPOSITIONAL AND TECTONIC EVENTS */

expl /* I am trying to determine if you have a basin located near an old craton margin that is tilted seaward and has more than one depositional or tectonic cycle. */yes MULTI no ALT

space MULTI desc $/^{*}$ Evidence of an irregular basin tilted seaward with multiple cycles that could possibly be a delta depocenter $* /$

ques $/ *$ HAS YOUR TYPE IIA CRATON MARGIN BASIN POSSIBLY BEEN MODIFIED BY A DELTA DEPOCENTER OF TERTIARY AGE AND IS TILTED SEAWARD */

expl $/ *$ I am trying to determine if you have an asymmetrical, irregular, tilted, craton margin basin that has had additional modification by adding a subsequent delta depocenter cycle of deposition. */ yes DELTA no XTYPE

space DELTA desc $/ *$ Evidence of a Delta Basin within a cratonic margin basin */

announce $/^{*}$ Congratulations! You have identified a favorable geologic setting for petroleum potential and have a basin that has been the site for the development of a delta depocenter. This is one form of a Klemme type IV Delta Basin. */

ques $/ *$ DO YOU THINK THAT YOU HAVE A CLASS IIA BASIN */

expl /* I want you to check a list of analog basins which follow this question, if you think that you have a Class IIA basin. */ yes ANAL no ALT

space XTYPE desc $/^{*}$ Evidence possibly of a multicycle basin other than the type IIA Craton Margin Basin or the type IV Delta Basin */

inf $/^{*}$ If you have a multicycle basin that does not meet the criteria for the type IIA or type IV basin you probably have a basin that would be classified as one of the other basin models in this World Basin Classification System. Check Klemme basin types IIIA and IIIC, models 5 and 7. */

space ANAL desc $/ *$ Evidence of an analog basin */

ques $/ *$ DO YOU HAVE ONE OF THE FOLLOWING BASINS OR A SIMILAR BASIN: ALBERTA, ANADARKO, ANDERSON, APPALACHIAN, ARDMORE, ARKOMA, BEAR LAKE, BIG HORN, BLACK WARRIOR, CHIHUAHUA, CRAZY MOUNTAINS, DALHART, EAGLE, FORT WORTH, GASPE, GREEN RIVER, HENRY MTS, KAIPAROWITS, LARAMIE, LIARD, MACKENZIE PLAINS, MELVILLE, NORTH PARK, MARATHON-OUACHITA-EASTERN OVERTHRUST, PALO DURO, SOUTH PARK, PEEL, PERMIAN, POWDER RIVER, ROCKY MTS, SAND WASH, UINTA, WASHAKIE, WESTERN OVERTHRUST, WIND RIVER, ACRE, NW ARGENTINA, BENI, CHACO, LLANOS DE CASANARE, MADRE DE DIOS, MAGALLANES, MALVINAS, ORIENTE, PUTUMAYO, UCAYALI, YARI, KAROO, NGALIA, REGGANE, TINDOUF, AMADEUS, EAST OFFICER, SHANGANNING, SICHUAN, ANABAR-LENA, ANGARA-LENA, IRKUTSK, KANSK, VERKHOYANSK, VILYUY, VOLGA-URAL, YENISEY-KHATANGA */

$\operatorname{expl} /^{*}$ I am trying to determine if your basin is one of these specific basins or a basin similar, geologically, to these basins. */ yes IIA no IV

space IIA desc $/ *$ Evidence of a Class IIA basin */

inf $/^{*}$ Congratulations! You have classified your basin as a Continental multicycle craton margin basin of the

Klemme Class IIA. You have also identified one of the basins on the list of analog basins that have been classified by Klemme as a Class IIA basin. You are now ready to make a more detailed analysis of your basin. $* /$ 
space IV desc $/ *$ Evidence of a type IV basin similar to the Mahakan, Po, Mackenzie, Niger or Mississippi */

inf $/^{*}$ Congratulations! You may have a modified Delta Class IV basin. Check model 8 in this classification system. */

STOP 


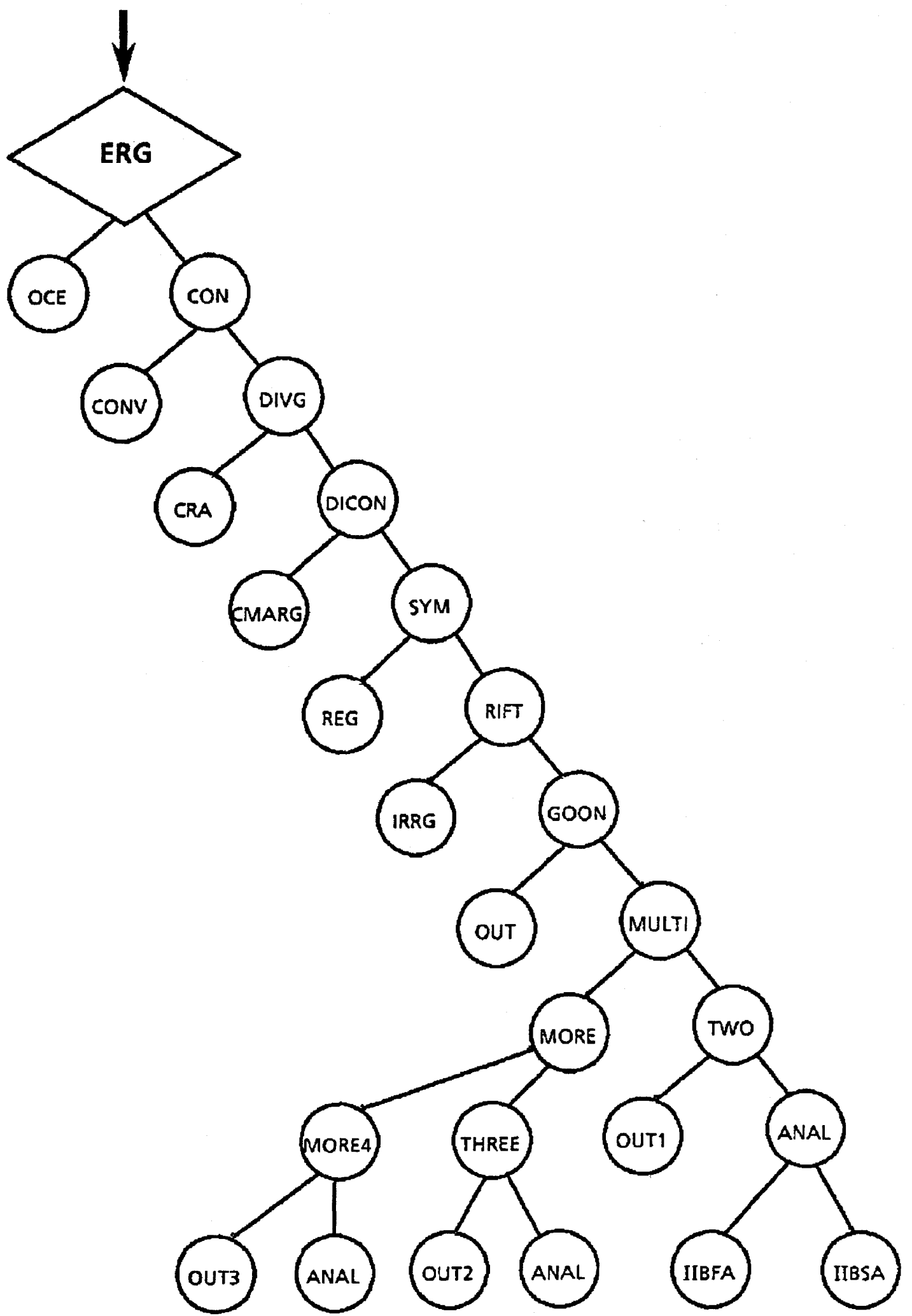

Inference net for Class IIB-Craton-Accreted Margin Complex Basins (model 3), file name IIBCAMB. 
model IIBCAMB

topspace ERG

space ERG desc $/ *$ Evidence of a continental basin, rather than an oceanic basin */

ques $/ *$ DO YOU HAVE A BASIN WHOSE POSITION IS LOCATED ON A CONTINENTAL CRUSTAL ZONE OR PLATE AS OPPOSED TO BEING LOCATED ON AN OCEANIC CRUSTAL ZONE OR PLATE */

expl $/^{*}$ I am trying to determine if the basin's position relative to the Earth's major crustal zones is continental rather than being located on oceanic crust. */ yes CON no OCE

space OCE desc $/^{*}$ Evidence of basins located on oceanic crust or partially on oceanic crust */

$\inf /^{*}$ Your basin is an oceanic basin located primarily on oceanic crust. You will need to check other basin models in this basin classification system, particularly the Forearc Basins in Class V. */

space CON desc $/ *$ Evidence of a divergent continental basin */

ques $l^{*}$ IS YOUR BASIN LOCATED IN AN AREA OF PRIMARILY DIVERGENT (OR EXTENSIONAL) PLATE MOVEMENT */

expl $/^{*} \mathrm{I}$ am trying to determine if the basin's position is on a divergent rather than a convergent continental crust. */yes DIVG no CONV

space CONV desc $/ *$ Evidence of a convergent continental basin */

$\inf /^{*}$ There is evidence that your basin is located on a convergent continental plate, at or near the margins of a craton. You may have a basin of the Class IIC type, which you should check. */

space DIVG desc $/^{*}$ Evidence of a divergent, continental basin located near the craton margin or on a cratonaccreted zone */

ques $/ *$ IS YOUR BASIN LOCATED SLIGHTLY INTERIOR TO THE CRATON MARGIN, OR PARTIALLY ON THE MARGIN OF THE CRATON AND PARTIALLY ON A ZONE ACCRETED TO THE CRATON, OR COMPLETELY ON A CRATON-ACCRETED ZONE, AS OPPOSED TO BEING DESCRIBED AS A CRATON INTERIOR BASIN */

expl $/^{*}$ I am trying to determine if your basin is located partially or completely on a craton-accreted zone, or even partially on the accreted zone and partially on the craton margin, and not what would be described as a craton interior basin. */ yes DICON no CRA

space CRA desc $/ *$ Evidence of a craton interior basin */

inf $/^{*}$ There is evidence that you have a divergent, continental, craton interior basin. You should check the Class I basins. */

space DICON desc /* Evidence of a symmetrical basin */

ques $/ *$ DO YOU HAVE A NEAR-MARGIN CRATON BASIN OR AN ACCRETED MARGIN BASIN WHOSE CROSS SECTION IS SYMMETRICAL IN SHAPE */

expl /* I am trying to determine whether your basin has a symmetrical cross section as opposed to an asymmetrical cross section. */ yes SYM no CMARG

space CMARG desc /* Evidence of a Class IIA basin */

inf $/^{*}$ There is evidence that you have an asymmetrical divergent, continental, craton margin basin. You should check the Class IIA basins. */

space SYM desc $/ *$ Evidence of an irregular, symmetrical basin */

ques $/ *$ DO YOU HAVE A NEAR-MARGIN CRATONIC BASIN WITH AN IRREGULAR BASEMENT

PROFILE DUE TO MULTIPLE RIFTS AND RIFT-FILL DISPLAYING A RANDOM ORIENTATION, AS OPPOSED TO A REGULAR (SMOOTH) BASEMENT PROFILE WITH LITTLE OR NO RIFTING */. 
expl /* I am trying to determine if you have a continental basin whose basement has been modified by random rift faulting and rift-fill as opposed to a basement profile that has not been modified by faulting. */ yes RIFT no REG

space REG desc $/ *$ Evidence of a regular, symmetrical basin */

inf $/^{*}$ There is no evidence that your basin has a rifted basement with an irregular basement profile. You may have a simple craton interior basin of the Class I type, or possibly even a Class IIA type. You should check these other basins further. */

space RIFT desc /* Evidence of a rifted-sag basin */

ques $/ *$ DO YOU HAVE A CRATON MARGIN OR ACCRETED-ZONE BASIN WHOSE RIFTED BASEMENT WITH RIFT FILL IS OVERLAIN BY A SIMPLE REGIONAL, SYMMETRICAL, CIRCULAR TO LOBATE EXTENSIONAL SAG, AS OPPOSED TO MORE COMPLEX TECTONIC BASIN MODIFICATIONS */

expl /* I am trying to determine whether the cross-sectional form of your basin shows: first, a rift and rift-fill, then followed by a regional extensional sag, as opposed to a basin with a more complex tectonic history. */yes GOON no IRRG

space IRRG desc $/ *$ Evidence of a craton-accreted zone basin */

inf $/^{*}$ You may have a more complex craton and/or accreted zone rift basin of the Klemme Class IIIA type. You should check out this class IIIA basin type in basin model 6. It is also possible that you do have a Class IIB basin but have insufficient data to answer relative to the deeper basin geology. Recheck your basin data and rerun the option of your choice. */

space GOON desc $/ *$ Evidence of a Class IIB basin */

announce $/ *$ Congratulations! You have identified a favorable geologic setting for the occurrence of petroleum resources in a Continental Multicycle Basin that is one of several forms of a Klemme type IIB basin. You may have either a rifted cratonic basin or a rifted accreted cratonic margin basin. The following questions are intended to aid in evaluating this possibility more fully. */

ques /* DO YOU HAVE A MULTICYCLE BASIN IN WHICH TWO OR MORE DEPOSITIONAL CYCLES HAVE TAKEN PLACE AND TWO OR MORE TECTONIC CYCLES HAVE TAKEN PLACE AS OPPOSED TO A SINGLE CYCLE BASIN */

expl /* I am trying to determine whether your accreted margin basin has a history of more than a single depositional and/or tectonic cycle. */ yes MULTI no OUT

space OUT desc $/^{*}$ Evidence of a single cycle basin */

inf $/^{*}$ You either have a simple, single cycle basin of the Class IIB type and are possibly missing some important data relative to the basin's history OR you may have a Class I basin and should recheck your classification models. $* /$

space MULTI desc $/^{*}$ Evidence of a two-cycle basin and the cycle sequence */

ques $/ *$ DOES YOUR BASIN HAVE A FIRST CYCLE OF RIFT AND RIFT-FILL ON AN ACCRETED ZONE, FOLLOWED BY A CIRCULAR, LOBATE OR LINEAR SAG SEQUENCE FOR A TWO-CYCLE BASIN AS OPPOSED TO MORE THAN TWO CYCLES */ MORE

expl $/^{*}$ I am trying to determine the number and sequence of the rift, rift-fill, and sag cycles. */yes TWO no

space TWO desc $/ *$ Evidence of a two-cycle Class IIB basin */

announce $/^{*}$ Congratulations! You have identified a two-cycle or two-sequence Craton-Accreted Margin Complex basin of the Klemme Class IIB type. $/$ 
ques ${ }^{*}$ DO YOU THINK YOU HAVE A KLEMME CLASS IIB (TWO-CYCLE) BASIN OF THIS TYPE AND WOULD YOU LIKE TO CHECK THE ANALOG BASIN LIST FOR CLASS IIB BASINS */

expl /* I want you to check a list of analog basins for Class IIB basins classified by Klemme as Class IIB types, so please answer YES. */ yes ANAL no OUT1

space OUT1 desc /* Evidence of an analog Class IIB basin */

inf $/^{*}$ You have identified a two-cycle Class IIB basin. However, you have chosen, for whatever reason, not to check out Klemme's list of analog basins classified as Class IIB basins. If you are missing essential information about your basin or about the analog basins, you may wish to collect more data and rerun your basin classification procedures. */

space MORE desc $/ *$ Evidence of a three-cycle Class IIB basin */

ques $/ *$ DO YOU HAVE AN ACCRETED CRATON MARGIN BASIN IN WHICH THE FIRST CYCLE IS A PLATFORM WEDGE ONLAPPING ON A CRATON, A SECOND CYCLE WITH RIFT FAULTING AND RIFT-FILL, FOLLOWED BY A THIRD CYCLE OF A CIRCULAR, LOBATE, OR LINEAR SAG OR HALF-SAG SEQUENCE, AS OPPOSED TO A BASIN WITH MORE THAN THREE CYCLES */ expl $/ *$ I am trying to determine if you have a three-cycle Class IIB basin. */ yes THREE no MORE4

space THREE desc $/ *$ Evidence of a three-cycle Klemme Class IIB basin */ announce $/^{*}$ Congratulations! You have identified a Klemme Class IIB Craton-Accreted Margin Complex basin with three depositional and tectonic cycles or sequences. $* /$

ques $/ *$ IF YOU AGREE THAT YOU HAVE A (THREE-CYCLE) KLEMME CLASS IIB BASIN OF THIS TYPE, WOULD YOU LIKE TO CHECK THE ANALOG BASIN LIST FOR THE CLASS IIB BASINS */ expl /* I want you to check the list of analog basins classified by Klemme as Class IIB basins, so if you think you have a Class IIB basin, answer YES. */ yes ANAL no OUT2

space OUT2 desc $/ *$ Uncertainty for a Class IIB basin *

inf $/^{*}$ It would appear that you have a three-cycle Class IIB basin. However, you have answered that you either do not think your basin is a three-cycle Class IIB basin for some reason, OR you do not want to run a check of the analog basins that Klemme has classified as Class IIB basins. You may have insufficient information relative to your basin, or relative to the analog basins, that makes you feel uncertain. You might wish to collect more data and rerun your basin classification procedures. ${ }^{*} /$

space MORE4 desc /* Evidence of a four-cycle Klemme Class IIB basin */

announce $/^{*}$ Congratulations! You have identified a Klemme Class IIB Craton-Accreted Margin Complex basin with at least four depositional and tectonic cycles or sequences. *

ques $/ *$ IF YOU THINK THAT YOU HAVE A (FOUR OR MORE CYCLES) KLEMME CLASS IIB BASIN OF THIS TYPE, WOULD YOU LIKE TO CHECK THE BASIN ANALOG LIST FOR CLASS IIB BASINS *I

expl /* I want you to check the list of analog basins classified by Klemme as Class IIB basins, so if you think you have a Klemme Class IIB basin of four or more cycles, answer YES. */ yes ANAL no OUT3

space OUT3 desc /* Uncertainty for a Class IIB basin */

inf $/^{*}$ It would appear that you have a four-cycle Class IIB basin. However, you have answered either that you do not think that you have a four or more cycle Class IIB basin for some reason, OR you do not want to run a check of the analog basins that Klemme has classified as Class IIB basins. You may have insufficient information relative to your basin or relative to the analog basins that makes you feel uncertain. You might wish to collect more data and rerun your basin classification procedures. */

space ANAL desc $/ *$ Evidence of a Class IIB analog basin */

ques $/ *$ DO YOU HAVE ONE OF THE FOLLOWING BASINS OR A SIMILAR BASIN: BLACK MESA, 
KNUD RASMUSSEN, MID-GREENLAND, PARADOX, PICEANCE, RATON, SAN JUAN, SAN LUIS, CUYO, NEUQUEN, PIEDRABUENA, SAN JULIAN, VALDEZ, COLOMB-BECHAR, GHADAMES, GIUBA, HAFUN, KALAHARI, KENYA, MBARANGANDU, MUDUGH, SAHARA, TIMIMOUN, ZAIRE, CUENCA, DUERO, NORTHWEST GERMAN, IRISH, KATTEGAT, MORELLA, SOUTHERN NORTH SEA, PARIS, SKAGGERAK, SIRET, WESSEX, ADAVALE, AGUSAN, ARCKARINGA, BOWEN, CANNING, COOPER, GALILEE, GUANGXI-GUIZOU, MURRAY, WEST OFFICER, PEDIRKA, SURAT, KARA SEA, KUZNETS, LAPTEV, PECHORA, TENGIZ, TURGAY, UST URT, WEST SERBERIA, DUFEK, MARIE BYRD, ROSS EAST, ROSS WEST, WEDDELL, WILKES */

expl /* These are the analog basins for the IIB Class as classified by Klemme. I am trying to determine if the basin that you are attempting to classify is one of the analog basins as classified by Klemme as a Class IIB basin, or a basin that is similar in geology to one of these basins. In either of these two cases, answer Yes. */ yes IIBSA no IIBFA

space IIBSA desc $/ *$ Evidence of an analog IIB Class basin */

inf $/ *$ Congratulations! You have successfully identified your basin as one of the classic basins in the Klemme Class IIB Continental Multicycle Craton-Accreted Margin (Complex) Basins, and you have either one of Klemme's analog basins (classified by Klemme as a Class IIB basin) or a basin with a similar regional geologic history. You are now ready to make a more detailed analysis of your basin. */

space IIBFA desc $/ *$ Evidence of an unsuccessful analog IIB Class basin match */

inf $/ *$ A partial congratulations! You have successfully identified your basin as being a Klemme Class IIB Continental Multicycle Craton-Accreted Margin Complex Basin. However, you have not successfully matched your basin with one of the Klemme Class IIB analog basins, nor have you indicated that your basin has a geology similar to any one of the Klemme analog basins. You may have insufficient geologic information on either your basin or on the analog basins to make a successful comparison, or you may have a Klemme Class IIIA basin which is similar in some respects to a IIB basin. You should recheck your basin information and rerun the classification system. Good Luck! */ 


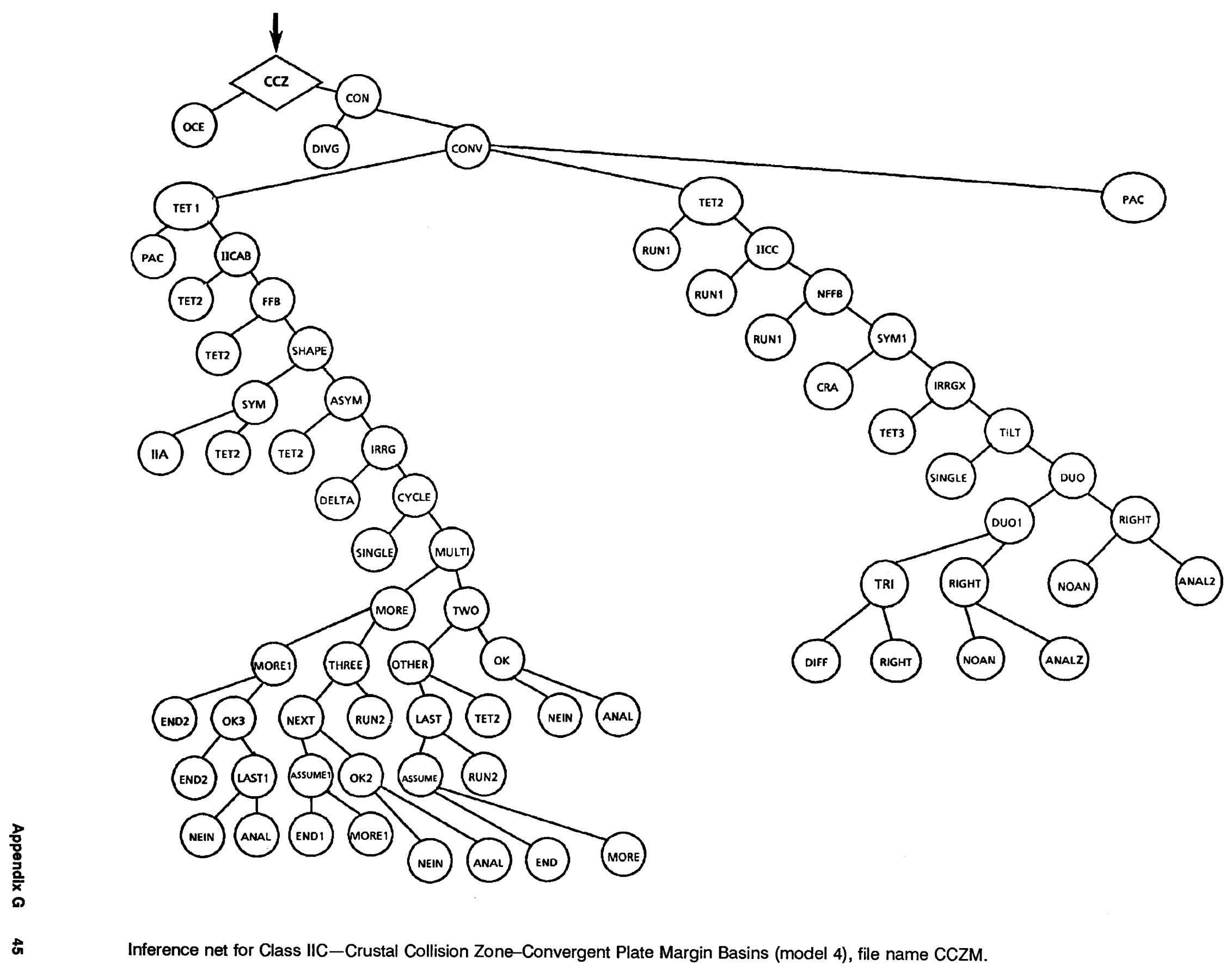

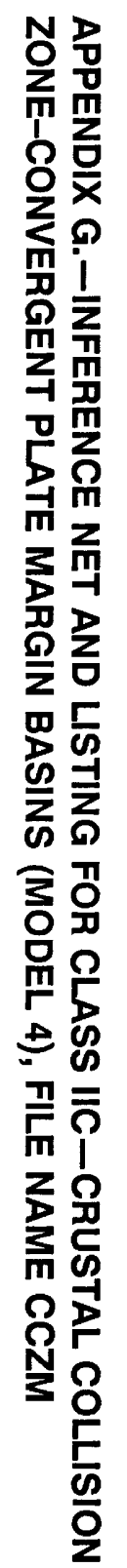


model CCZM

topspace $\mathrm{CCZ}$

space CCZ desc /* Location of prospective basin relative to continental rather than oceanic crust */

ques $/ *$ IS YOUR BASIN LOCATED ON CONTINENTAL CRUST OR PRIMARILY CONTINENTAL CRUST (PLATES), AS OPPOSED TO BEING LOCATED PRIMARILY ON OCEANIC CRUST OR OCEANIC PLATES */

expl $/^{*}$ I am trying to determine if the position of the basin relative to the Earth's major crustal zones is predominantly on continental rather than on oceanic crust */ yes CON no OCE

space OCE desc $/ *$ Basins located on oceanic crust or partially on oceanic crust */

inf $/^{*}$ Your basin is an oceanic basin located primarily on oceanic crust. You should check the other basin models, particularly Class V (basin model 9), in the world basin classification system. */

space CON desc /* Evidence of a continental basin located along a craton or pericratonic margin */ ques $/^{*}$ IS YOUR BASIN LOCATED ON CONVERGING CONTINENTAL PLATES IN AN AREA OF A MAJOR COLLISIONAL ZONE, AS OPPOSED TO BEING LOCATED IN AN AREA OF DIVERGENT OR EXTENSIONAL PLATE MOVEMENT */

expl $/^{*}$ I am trying to determine whether your basin is found in an area of continental plate convergence, rather than in an area of major extensional or divergent plate movement */yes CONV no DIVG

space DIVG desc $/ *$ Evidence of a continental basin that may be of a divergent nature */

inf $/^{*}$ You may have a continental basin that occurs along a divergent margin or is of an extensional nature, and currently is not located in a major zone of converging continental plates in collision. Check other basin classes, particularly Classes I, IIB, IIIA, IIIC, and IV (models 1, 3, 5, 7 and 8), in this world basin classification system. */

space CONV desc $/^{*}$ Location of prospective basin relative to the type of convergent margin on which the basin was formed *I

expl $/^{*}$ I am trying to determine which type of tectonic location for the basin may best describe the nature of the convergent margin, i.e., a basin on a convergent-collision margin or a basin on a convergent-consumption margin */

announce $/^{*}$ The following is intended to aid in the classification of various types of convergent margin basins */

choices /* PAC TET1 TET2 */

space PAC desc $/^{*}$ Evidence of basins located along the periphery of the Pacific Ocean, and including the Antarctic Ocean */

noun-phrase /* Circum-Pacific Convergent Basins */

inf $/^{*}$ Your basin, if bordering the margins of the Pacific Ocean or the Antarctic Ocean along what have been termed convergent and transform margins, are probably classified as rifted convergent margin basins (Class IIIB) or forearc basins (Class V) in this world basin classification system. Please check basin models 6 and 9. */

space TET3 desc $/ *$ Evidence of a rifted convergent margin basin of the oceanic consumption type */

inf $/^{*}$ Your basin may be of the rifted convergent margin type in an area of oceanic consumption and be classified as a Class IIIB (model 6) in this world basin classification system. You should check this basin class. */

space TET1 desc $/ *$ Evidence of convergent margin collision zone basins */ noun-phrase $/ *$ Convergent Margin Collision Zone Northern and Southern Tethyan Basins */ ques ${ }^{*}$ IS YOUR BASIN LOCATED IN EITHER SOUTHEAST ASIA, THE HIMALAYAN-ALPINE CHAIN FROM THE SOLOMON ISLANDS THROUGH THE MEDITERRANEAN TO SPAIN, OR WITHIN THE CARIBBEAN (ANTILLES ARC) AREA */ 
expl /* I am trying to determine if your basin is located in the major collision zone between Gondwana and Laurasia, sometimes referred to as the Tethys */ yes IICAB no PAC

space IICAB desc $/^{*}$ Evidence of a Northern or Southern Tethys basin */

ques $/ *$ IS YOUR BASIN LOCATED ALONG EITHER A PRESENT OR FOSSIL PLATE MARGIN IN THE NORTHERN OR SOUTHERN TETHYS THAT IS, OR WAS, DOWNWARPED INTO A SMALL OCEAN BASIN */

$\operatorname{expl} / *$ I am trying to determine if your basin is located in the Northern or Southern Tethys as a closed or trough basin, as opposed to being located in the Central Tethys as an open basin */ yes FFB no TET2

space FFB desc $/ *$ Evidence of an orogenically (collisional) derived foredeep and foldbelt basin */

ques $l^{*}$ DO YOU HAVE A BASIN LOCATED WITHIN THE TETHYS THAT HAS AN OROGENICALLY (COLLISIONALLY) DERIVED FOREDEEP AND FOLDBELT */

expl $/ *$ I am trying to determine if you have a Tethyan basin that has an orogenically derived foredeep and foldbelt, as opposed to a basin that is either opening or closing but does not have an orogenically derived foredeep and foldbelt developed */yes SHAPE no TET2

space SHAPE desc $/ *$ Evidence of an asymmetrical Tethyan basin */

ques $/ *$ DO YOU HAVE A BASIN THAT IS ASYMMETRICAL IN PROFILE DUE TO AN OROGENICALLY DERIVED FOREDEEP AND FOLDBELT IMPARTING ASYMMETRY TO THE FORELAND CONTINENTAL CRUST, AS OPPOSED TO A BASIN WITH A SYMMETRICAL PROFILE */

expl /* I am trying to determine if your Tethyan basin has an asymmetrical profile rather than a symmetrical basin profile */ yes ASYM no SYM

space SYM desc $/ *$ Evidence of an irregular symmetrical basin */

ques $/ *$ DO YOU HAVE A BASIN ESSENTIALLY SYMMETRICAL IN PROFILE BUT WITH AN IRREGULAR SEDIMENT TO BASEMENT CONTACT DUE TO SINGLE OR MULTIPLE RIFT FAULTING OVERLAIN BY A LINEAR HALF SAG, OR EVEN A PLATFORM WEDGE ORIENTED DOWNDIP AND SEAWARD AND LOCATED INSIDE TETHYS, AS OPPOSED TO A SYMMETRICAL BASIN WITH A REGULAR SEDIMENT TO BASEMENT CONTACT */

expl /* I am trying to determine if you have a basin located inside Tethys that has an irregular symmetrical profile on either accreted zone or craton, and often overlapping intermediate to oceanic crust, with a single or multiple rifted basement overlain by a linear half sag or platform wedge that is oriented downdip and seaward $* /$ yes TET2 no IIA

space IIA desc $/ *$ Evidence of a symmetrical regular basin */

inf $/^{*}$ From the description of your basin it would appear that you may be missing crucial tectonic information about your basin and that you do have some form of a Tethyan basin, OR you may actually have a different type of basin best described by Classes I, IIA or IIB that lie outside the Tethys. Please check basin models 1,2 or 3. ${ }^{*} /$

space ASYM desc $/ *$ Evidence of an irregular asymmetrical Tethyan basin */

ques $/ *$ DO YOU HAVE AN INSIDE TETHYAN BASIN THAT HAS AN ASYMMETRICAL PROFILE WITH IRREGULAR BASEMENT CONTACT DUE TO BASEMENT RIFTING ON EITHER A CRATON OR ACCRETED ZONE, AND OVERLAIN BY A MESOZOIC OR TERTIARY OROGENICALLY DERIVED FOREDEEP THAT IMPARTED ASYMMETRY TO THE FORELAND */

expl $/^{*}$ I am trying to determine if you have a Northern or Southern Tethyan basin with an asymmetrical profile and with an irregular basement contact due to rifting */yes IRRG no TET2

space IRRG desc $/^{*}$ Evidence of a Tethyan basin UNMODIFIED by a delta depocenter of Tertiary age */ announce ${ }^{*}$ Congratulations! You have identified what would appear to be an irregular, asymmetrical 
northern or southern Tethyan basin. The following questions are intended to aid in evaluating this basin more fully. ${ }^{*} /$

ques $/^{*}$ DO YOU HAVE AN ASYMMETRICAL, IRREGULAR TETHYAN BASIN THAT HAS NOT BEEN FURTHER MODIFIED BY A DELTA DEPOCENTER OF TERTIARY AGE, AND THEN TILTED SEAWARD *

expl $/^{*}$ I am trying to determine if your Tethyan basin has been unmodified by any later deposition of a delta depocenter of Tertiary age superimposed within the basin, and the basin then tilted seaward */ yes CYCLE no DELTA

space DELTA desc $/^{*}$ Evidence of a Delta depocenter basin */

inf $/^{*}$ You may have a Tethyan basin that has been modified by a later delta depocenter of Tertiary age. You should check the Class IV Delta Basins (model 8) description in this world basin classification system. */

space CYCLE desc $/ *$ Evidence of a Tethyan basin with at least two major morphologic cycles or sequences */

ques $/ *$ DO YOU HAVE A TETHYAN BASIN WITH AT LEAST TWO MAJOR MORPHOLOGIC CYCLES OR SEQUENCES */

expl $/^{*}$ I am trying to determine if your basin has at least two major morphologic cycles, as opposed to a single cycle basin */ yes MULTI no SINGLE

space SINGLE desc $/ *$ Evidence of a single cycle basin */

inf $/^{*}$ You have described a single cycle basin that may be either a Tethyan basin in which you may be missing important information relative to more depositional or tectonic cycles, or you may have any one of the following non-Tethyan basins: Klemme Basin Classes I, IIB, IV, or V (models 1, 3, 8 or 9). You may wish to check these other basin classifications. $* /$

space MULTI desc /* Evidence of a two-cycle basin */

ques $/ *$ DO YOU HAVE ONLY A TWO-CYCLE BASIN */

expl /* I am trying to determine if you have a basin with exactly two cycles. If you have a basin with more than two cycles then answer NO */ yes TWO no MORE

space TWO desc $/ *$ Evidence of the first type of two-cycle Tethyan basin */

ques ${ }^{*}$ DO YOU HAVE AN INSIDE TETHYAN BASIN WHOSE FIRST CYCLE IS A PLATFORM WEDGE THAT ONLAPS EITHER ON THE CRATON OR AN ACCRETED ZONE, FOLLOWED BY A SECOND CYCLE WITH A FOREDEEP AND FOLDBELT THAT DEVELOPS ASYMMETRY AND HAS A FORELAND RAMP ON EITHER THE CRATON OR ACCRETED ZONE */

expl /*I am trying to determine if you have only a two-cycle Tethyan basin that has the two cycles described exactly as in the question. If your two basin cycles are not exactly as described above, then answer NO */ yes OK no OTHER

space OK desc $/^{*}$ Evidence of the second type of two-cycle Tethyan (closed or trough) basin */

announce $/^{*}$ Congratulations! You have described a two-cycle northern or southern Tethyan basin of the Klemme Class II type Continental Multicycle basin, either a class IICa or IICb Crustal Collision Zone-Convergent Plate Margin Basin of either the closed (IICa) or the trough type (IICb). */

ques $/ *$ DO YOU HAVE ANY ONE OF THE FOLLOWING BASINS OR ANALOG TYPE BASINS AS CLASSIFIED BY KLEMME AS EITHER IICa OR IICb: CAMPECHE, MATURIN, PARIA, ATLAS, CYRENAICA, EASTERN MEDITERRANEAN, NILE, PELAGIAN, RHARB, WESTERN DESERT, NORTH AND SOUTH ADRIATIC, CALTANISETTA, CANKIRI, CARPATHIAN, DIYARBAKIR, EBRO, GAZIANTEP, GUADALQUIVIR, IONIAN, MOESIAN, MOLASSE, PO, TARANTO, TERRE NOIR, UPPER SILESIAN, ARABIAN, LEVANTINE, OMAN GULF, SINAI, ZAGROS, ARAFURA, ASSAM, BENGAL, BINTOENIA, CERAM, GANGES, INDUS, KHORAT, MOREHEAD, NEW GUINEA, PAPUAN, POTWAR, SALAWATI, 
TARIM, NORTH CASPIAN, NORTH CAUCASUS, KARA-KUM, KOPET-DAG, MANGYSHLAK, TADZHIK, OR TURKMEN */

expl /* I am trying to determine if you have any one of the basins or basin analogs that Klemme has classified as a Class IICa or IICb basin */ yes ANAL no NEIN

space ANAL desc /* Evidence of a successful selection of a Klemme IICa or IICb basin analog */

inf $/^{*}$ Congratulations! Not only have you successfully classified your basin as a IICa or IICb basin, but you have also identified your basin as one of the basins classified as such by Klemme. You are now ready for a more detailed analysis of your basin. */

space NEIN desc $/ *$ Lack of evidence for a IICa or a IICb basin */

inf $l^{*}$ You did not select any of the analog basins for a Klemme IICa or IICb Tethyan basin. Therefore it is a good possibility that you may have either: a Klemme IICc basin and therefore should rerun this model and select the Central Tethyan open basin option, OR you have a basin that does not fit the characteristics of a Class II basin and should consider some of the other basin models in this basin classification system, OR you may be missing some crucial information relative to your basin which may complicate classifying the basin. In any case, you need to reconsider your basin information and rerun this program. $* /$

space OTHER desc $/ *$ Evidence of another type of two-cycle Tethyan basin */

ques $/ *$ DO YOU HAVE A TWO CYCLE TETHYAN BASIN WHOSE FIRST CYCLE IS A RIFT AND RIFT-FILL ON AN ACCRETED ZONE, FOLLOWED BY A SECOND CYCLE OF A CIRCULAR, LOBATE, OR LINEAR SAG SEQUENCE WITHIN THE CENTRAL TETHYS, WHERE CONVERGENT COLLISION FORMS TENSION AND WRENCH RIFT AND SAG CYCLES OF POST UPPER CRETACEOUS AGE */

expl /* I am trying to determine if you have a two-cycle, inside, Central Tethys basin, with the exact cycle description as listed in the question. If you have a two-cycle Tethyan basin that does not exactly fit the description as worded in the question, then answer NO */ yes TET2 no LAST

space LAST desc $/ *$ Evidence of a third type of two-cycle Tethyan basin */

ques $/^{*}$ DO YOU HAVE A TWO-CYCLE TETHYAN BASIN WHOSE FIRST CYCLE IS A RIFT AND RIFT-FILL ON AN ACCRETED ZONE, FOLLOWED BY A SECOND CYCLE OF A CIRCULAR, LOBATE, OR LINEAR SAG SEQUENCE LOCATED INSIDE THE TETHYS IN A COASTAL ZONE OF INLAND SEAS AND GULFS, WITH THE DEVELOPMENT OF UNIDIRECTIONAL RIFTING AND HALF-SAG SEAWARD DOWNWARPS */

expl /* I am trying to determine if you have a two-cycle Tethyan basin with the exact description of cycles as given in the question, and located as an inside Tethys basin in a coastal zone of inland seas and gulfs. If your two-cycle basin does not exactly fit the description and sequence in the question then answer No */ yes RUN2 no ASSUME

space ASSUME desc /* Favorable assumption for more than a two cycle Tethyan basin */

ques $/ *$ WOULD YOU LIKE TO ASSUME THAT YOU MAY HAVE MORE THAN TWO MAJOR MORPHOLOGIC CYCLES OR SEQUENCES IN YOUR TETHYAN BASIN */

expl /* You have described a two-cycle Tethyan basin that does not fit any of the three two-cycle Tethyan basins as described by Klemme. You may have important tectonic or depositional information missing that would indicate more than a two-cycle basin. If so, and you wish to assume more than two cycles may exist in your basin, answer YES */ yes MORE no END

space END desc $/ *$ Evidence of a two cycle non-Tethyan basin */

inf $/^{*}$ You have described a two-cycle basin that does not fit the description of any of the Klemme two-cycle basins within the classes for IICa or IICb or IICc or IIIB. I would recommend that you check other basin models that describe non-Tethyan basins in this basin classification system. */ 
space MORE desc /* Evidence of a three-cycle Tethyan basin */

ques $/ *$ DO YOU HAVE A THREE-CYCLE TETHYAN BASIN */

expl /* I am trying to determine if you have exactly a three cycle Tethyan basin. If you have more than three cycles then answer NO */ yes THREE no MORE1

space THREE desc $/ *$ Evidence of the first of three cycle Tethyan basins */

ques $/^{*}$ DO YOU HAVE A THREE-CYCLE TETHYAN BASIN WHOSE FIRST CYCLE IS A PLATFORM WEDGE (OFTEN PARTIALLY ERODED) THAT ONLAPS THE CRATON, FOLLOWED BY A SECOND CYCLE OF RIFT AND RIFT-FILL, FOLLOWED BY A THIRD CYCLE OF CIRCULAR, LOBATE, LINEAR SAG OR HALF SAG CYCLE AND SEQUENCE, WITH BASIN LOCATION INSIDE THE CENTRAL TETHYS IN A COASTAL ZONE OF INLAND SEAS AND GULFS WHERE THE SECOND CYCLE OF UNIDIRECTIONAL RIFTING DOWNDROPS THE FIRST CYCLE CRATON ONLAP AND IS OVERLAIN BY A THIRD CYCLE LINEAR, HALF SAG SEQUENCE DIRECTED SEAWARD */

expl $/^{*}$ I am trying to determine if you have a three-cycle Tethyan basin with the exact description and sequence of the three cycles as listed in the question and that is located in a coastal zone of inland seas and gulfs. If your three-cycle basin does not exactly fit the three-cycle sequence as given in the question, then answer NO */ yes RUN2 no NEXT

space NEXT desc /* Evidence of a second three-cycle Tethyan basin */

ques $/ *$ DO YOU HAVE A THREE-CYCLE TETHYAN BASIN WHOSE FIRST CYCLE INVOLVES A RIFT AND RIFT-FILL SEQUENCE ON AN ACCRETED ZONE, FOLLOWED BY A SECOND CYCLE OF A LINEAR TO LOBATE SAG, FOLLOWED BY A THIRD CYCLE OF A FOREDEEP AND FOLDBELT WHICH DEVELOPS ASYMMETRY AND A FORELAND RAMP ON THE ACCRETED ZONE, WITH BASIN LOCATION IN THE NORTHERN TETHYS WITH A THIRD CYCLE THAT OVERRIDES AND EITHER DESTROYS A SECOND CYCLE OR DOES NOT DESTROY THE SECOND CYCLE COMPLETELY */

expl $/^{*}$ I am trying to determine if you have a three-cycle Tethyan basin with the exact description and sequence of the three-cycle sequence as given in the question and a location in the northern Tethys. If you have the exact description and sequence as in the question, answer YES */ yes OK2 no ASSUM1

space OK2 desc /* Evidence of a three-cycle Tethyan (closed or trough) crustal collision-zone basin */

announce $/^{*}$ Congratulations! You have described a three-cycle closed or trough-type Tethyan basin of the Klemme Class II type Continental Multicycle basin, either a class IICa or IICb Crustal Collision Zone-Convergent Plate Margin Basin of either the closed (IICa) or the trough type (IICb). */

ques $/^{*}$ DO YOU HAVE ANY ONE OF THE FOLLOWING BASINS OR ANALOG TYPE BASINS AS CLASSIFIED BY KLEMME AS EITHER IICa OR IICb: CAMPECHE, MATURIN, PARIA, ATLAS, CYRENAICA, EASTERN MEDITERRANEAN, NILE, PELAGIAN, RHARB, WESTERN DESERT, NORTH AND SOUTH ADRIATIC, CALTANISETTA, CANKIRI, CARPATHIAN, DIYARBAKIR, EBRO, GAZIANTEP, GUADALQUIVIR, IONIAN, MOESIAN, MOLASSE, PO, TARANTO, TERRE NOIR, UPPER SILESIAN, ARABIAN, LEVANTINE, OMAN GULF, SINAI, ZAGROS, ARAFURA, ASSAM, BENGAL, BINTOENIA, CERAM, GANGES, INDUS, KHORAT, MOREHEAD, NEW GUINEA, PAPUAN, POTWAR, SALAWATI, TARIM, NORTH CASPIAN, NORTH CAUCASUS, KARA-KUM, KOPET-DAG, MANGYSHLAK, TADZHIK, OR TURKMEN */

expl $/^{*}$ I am trying to determine if you have any one of the basins or basin analogs that Klemme has classified as a Class IICa or IICb basin */ yes ANAL no NEIN

space ASSUM1 desc $/^{*}$ The favorable assumption of more than three cycles in a Tethyan basin */ ques /* WOULD YOU LIKE TO ASSUME THAT YOU MAY HAVE MORE THAN THREE MAJOR MORPHOLOGIC CYCLES OR SEQUENCES IN YOUR TETHYAN BASIN */

expl /* You have described a three-cycle Tethyan basin that does not fit the two three-cycle Tethyan basins as described by Klemme. You may have a four-cycle Tethyan basin in which you may have important information 
missing relative to another cycle. If you think you do, then I would recommend that you answer YES to this question */ yes MORE1 no END1

space END1 desc /* Description of another class of multicycle non-Tethyan basin */

inf $/^{*}$ You have described a three-cycle Tethyan basin that does not fit the descriptions by Klemme of a threecycle Tethyan basin. You may have important tectonic or depositional data missing on your basin or you may have another class of non-Tethyan multicycle basin. I would recommend that you check some of the other multicycle basin models in this world basin classification system. ${ }^{*}$ /

space MORE1 desc $/ *$ Evidence of a four-cycle Tethyan basin */

ques $/ *$ DO YOU HAVE A FOUR-CYCLE TETHYAN BASIN */

expl /* I am trying to determine if you have a four-cycle Tethyan basin */ yes OK3 no END2

space LAST1 desc /* Evidence of a four-cycle Tethyan (closed or trough) crustal collision-zone basin */

announce $/^{*}$ Congratulations! You have described a four-cycle closed or trough-type Tethyan basin of the Klemme Class II type Continental Multicycle basin, either a Class IICa or IICb Crustal Collision Zone-Convergent Plate Margin Basin of the closed (IICa) or the trough type (IICb). */

ques $/ *$ DO YOU HAVE ANY ONE OF THE FOLLOWING BASINS OR ANALOG TYPE BASINS AS CLASSIFIED BY KLEMME AS EITHER IICa OR IICb: CAMPECHE, MATURIN, PARIA, ATLAS, CYRENAICA, EASTERN MEDITERRANEAN, NILE, PELAGIAN, RHARB, WESTERN DESERT, NORTH AND SOUTH ADRIATIC, CALTANISETTA, CANKIRI, CARPATHIAN, DIYARBAKIR, EBRO, GAZIANTEP, GUADALQUIVIR, IONIAN, MOESIAN, MOLASSE, PO, TARANTO, TERRE NOIR, UPPER SILESIAN, ARABIAN, LEVANTINE, OMAN GULF, SINAI, ZAGROS, ARAFURA, ASSAM, BENGAL, BINTOENIA, CERAM, GANGES, INDUS, KHORAT, MOREHEAD, NEW GUINEA, PAPUAN, POTWAR, SALAWATI, TARIM, NORTH CASPIAN, NORTH CAUCASUS, KARA-KUM, KOPET-DAG, MANGYSHLAK, TADZHIK, OR TURKMEN */

expl /* I am trying to determine if you have any one of the basins or basin analogs that Klemme has classified as a Class IICa or IICb basin */ yes ANAL no NEIN

space OK3 desc $/^{*}$ Evidence of a four-cycle southern Tethys basin */

ques $/ *$ DO YOU HAVE A FOUR-CYCLE TETHYAN BASIN WHOSE FIRST CYCLE IS A PLATFORM WEDGE ONLAPPING A CRATON, FOLLOWED BY A SECOND CYCLE WITH RANDOM TO UNIDIRECTIONAL RIFT AND RIFT-FILL SEQUENCE POORLY TO MODERATELY WELL DEVELOPED, FOLLOWED BY A THIRD CYCLE OF A LINEAR TO LOBATE SAG SEQUENCE, FOLLOWED BY A FOURTH CYCLE OF A FOREDEEP AND FOLDBELT DEVELOPING ASYMMETRY AND A FORELAND RAMP ON A CRATON, AND WHERE THE BASIN IS LOCATED INSIDE THE SOUTHERN TETHYS WHERE PLATE MARGIN COLLISION OF CONTINENTAL CRUSTAL PLATES LIES IMMEDIATELY ADJACENT TO THE CRATION AND WHERE THE COLLISION HAS EITHER OVERRIDDEN OR DESTROYED THE SECOND AND THIRD CYCLE, OR WHERE THE SECOND AND THIRD CYCLES ARE PRESERVED IN A FORELAND RAMP */

expl /* This is a rather long and involved question, but first answer in terms of the exact description of the four-cycle sequence, then check the location for a southern Tethyan basin, and finally the either-or conditions of the second and third cycles described in the last part of the question. If you can answer YES to these three stages of the question, then your final answer should be YES. If you cannot answer yes to all three sets of conditions, then answer the entire question NO */ yes LAST1 no END2

space END2 desc /* Description of other multicycle non-Tethyan basins */

inf $/^{*}$ You have described a multicycle basin that does not fit the Klemme description of a multicycle Tethyan basin. You may have a multicycle Tethyan basin in which you are missing important tectonic and depositional 
information, or you may have another class of multicycle basin. I would recommend that you check the other multicycle basin models in this world basin classification system. */

space RUN2 desc /* Description of an open Tethyan Crustal Collision Zone-Convergent Plate Margin Basin */

inf $/^{*}$ From the description of your basin there is a very good possibility that you should have chosen the option of a Crustal Collision Zone-Convergent Plate Margin Basin located inside the Tethys with an open basin RATHER THAN this option for Crustal Collision Zone-Convergent Plate Margin Basin in the Northern or Southern Tethys. I would recommend that you rerun this model and then chose the third option out of the three options rather than running this second option. $* /$

space TET2 desc /* Evidence of an open Tethyan Crustal Collision Zone-Convergent Plate Margin Basin */ noun-phrase $/ *$ Crustal Collision Zone-Convergent Plate Margin Basin located inside the Tethys as an open basin */

ques $/ *$ DO YOU HAVE A LARGE TO MODERATE SIZED BASIN THAT DOWNWARPS INTO TETHYAN SEAWAYS (EAST MEDITERRANEAN, SOUTH CHINA SEA, BLACK SEA, OR GULF OF MEXICO), AND THAT IS EITHER OPENING OR CLOSING INTO A SMALL OCEAN BASIN */

expl /* I am trying to determine if you have an open Tethyan Crustal Collision Zone-Convergent Plate Margin Basin of the Class IICc type rather than a closed or trough Tethyan basin of the Class IICa or IICb type */ yes IICC no RUN1

space IICC desc $/ *$ Evidence of an open Crustal Collision Zone Basin downwarped into a small ocean basin */ ques $/ *$ DO YOU HAVE AN OPEN TETHYAN BASIN THAT DOES NOT HAVE AN OROGENICALLY DERIVED FOREDEEP AND FOLDBELT DEVELOPED AS IN THE CLASS IICa OR IICb TYPE */

expl $/^{*}$ I am trying to determine if your Tethyan basin does not have an orogenically derived foredeep and foldbelt. Answer YES if it does not have a foredeep and foldbelt */yes NFFB no RUN1

space NFFB desc /* Evidence of an open Tethys symmetrical basin */ ques $/ *$ DO YOU HAVE AN OPEN TETHYAN BASIN WITH A SYMMETRICAL BASEMENT PROFILE */ expl /* I am trying to determine if your open Tethyan basin has a symmetrical profile */ yes SYM1 no RUN1

space RUN1 desc $/ *$ Crustal Collision Zone-Convergent Plate Margin Basins, Classes IICa and IICb */

inf $l^{*}$ From the description of your basin there is a very good possibility that you should have chosen the option of a Crustal Collision Zone-Convergent Plate Margin Basin in Northern or Southern Tethys RATHER THAN this option of a Crustal Collision Zone-Convergent Plate Margin Basin located inside the Tethys as an open basin. I would recommend that you rerun this model and choose the second basin option (the Northern and Southern Tethys) rather than this (the third) option for the central open Tethys basin. UNLESS YOU DID START WITH THE SECOND OPTION AND THE NATURE OF YOUR ANSWERS HAD TRANSFERRED YOU TO THE THIRD OPTION. THEN I would recommend that you check some of the other convergent margin basin models such as that of the Class IIIB (model 6). */

space SYM1 desc $/ *$ Evidence of an irregular symmetrical open Tethyan basin */

ques $/ *$ DO YOU HAVE AN OPEN TETHYAN SYMMETRICAL BASIN WHOSE PROFILE WITH THE BASEMENT CONTACT IS IRREGULAR DUE TO RIFTING OF THE BASEMENT */

expl $/^{*}$ I am trying to determine if your Tethyan basin has an irregular basement contact due to rifting of the basement */ yes IRRGX no CRA

space CRA desc $/ *$ Description of a regular symmetrical basin */

inf $/^{*}$ You have described a symmetrical basin with a regular basement contact. You may either be missing tectonic information that would establish an irregular basement, or you may have a non-Tethyan basin of either the Class I or Class IV type. You may wish to check other basin models in this world basin classification system. */ 
space IRRGX desc $/ *$ Evidence of a symmetrical irregular tilted Tethyan basin */

ques $/ *$ DO YOU HAVE AN OPEN TETHYAN BASIN WHOSE PROFILE IS ONE OF AN IRREGULAR SYMMETRICAL BASIN THAT IS TILTED SEAWARD AND THAT IS LOCATED ON EITHER ACCRETED ZONE OR CRATON AND OFTEN OVERLAPPING INTERMEDIATE TO OCEANIC CRUST, WITH SINGLE OR MULTIPLE RIFTED BASEMENT, OVERLAIN BY A LINEAR HALF SAG PLATFORM WEDGE ORIENTED DOWNDIP AND SEAWARD */

expl /* I am trying to determine if your irregular symmetrical basin is tilted seaward and is located inside Tethys on either accreted zone or craton */ yes TILT no TET3

space TILT desc $/ *$ Evidence of a two-cycle open Tethyan basin */

ques $l^{*}$ DOES YOUR BASIN HAVE AT LEAST TWO MAJOR MORPHOLOGIC CYCLES OR SEQUENCES */

expl $/ *$ I am trying to determine if your basin is a two-cycle basin rather than a single-cycle basin */yes DUO no SINGLE

space DUO desc $/ *$ Evidence of the first two-cycle open Tethyan basin */

ques ${ }^{*}$ DO YOU HAVE A TWO-CYCLE BASIN WHOSE FIRST CYCLE IS RIFT AND RIFT-FILL ON AN ACCRETED ZONE, FOLLOWED BY A SECOND CYCLE OF A CIRCULAR, LOBATE, OR LINEAR SAG SEQUENCE THAT IS LOCATED INSIDE TETHYS IN A COASTAL ZONE OF INLAND SEAS AND GULFS, WITH UNIDIRECTIONAL RIFTING AND HALF SAG SEAWARD DOWNWARPS DEVELOPED */

expl $/ *$ I am trying to determine if your two-cycle basin has the exact description for the two-cycle sequence as listed in the question and if it is located in a coastal zone of inland seas and gulfs inside the Tethys. If the answer is yes for both parts of the question, then answer YES, otherwise answer NO */ yes RIGHT no DUO1

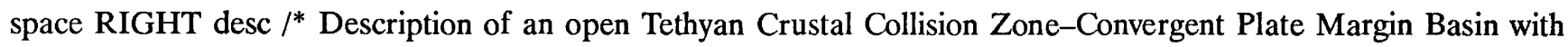
two or more cycles $* /$

announce $/^{*}$ Congratulations! You have described a two-cycle or a three-cycle open Tethyan basin of the Klemme IICc class: an open Crustal Collision Zone-Convergent Plate Margin Basin. */

ques $/ *$ DO YOU HAVE ONE OF THE FOLLOWING BASINS THAT HAS BEEN CLASSIFIED BY KLEMME AS A CLASS IICc BASIN: EAST TEXAS SALT DOME, CAMPECHE (YUCATAN BORDERLAND AND PLATFORM AND TOBASCO), FLORIDA DEEP, GULF COAST OF MEXICO AND TEXAS, LOUISIANA SALT DOME, MEXICAN OVERTHRUST, MISSISSIPPI FAN, MISSISSIPPI SALT DOME, NORTHEAST GULF SALT DOME, NORTH SLOPE, PETEN-CHIAPAS, SABINAS, SALINAS (MEXICO), SIGSBEE DEEP, SOUTH TEXAS SALT DOME, SVERDRUP, TAMPICO, BURDWOOD BANK, SOUTH GEORGIA, CYRENAICA, EAST MEDITERRANEAN, NILE, WESTERN DESERT, SINAI, BRUNEI-SABAH, SAIGON, SARAWAK, SOKANG, OR EAST SIBERIA */

expl /* I am trying to determine whether the basin that you are trying to classify is one of the basins or a similar basin as one of those listed in the question. All of the basins listed in the question have been classified by Klemme as Class IICc basins-Crustal Collision Zone-Convergent Plate Margin Basins downwarped into an open Tethys. */ yes ANAL2 no NOAN

space ANAL2 desc $/ *$ Evidence of a successful Class IICc basin match */

inf $/^{*}$ Congratulations! You have successfully classified your basin as a Class IICc basin and you have matched your basin with one of Klemme's Class IICc analog basins. You are now ready for a more detailed analysis of your basin. */

space NOAN desc $/^{*}$ Evidence of a partial success in classifying a Class IICc basin *

inf $/^{*}$ Congratulations! You have achieved a partial success in that you have classified your basin as a Class

IICc basin. However, you did not pick any one of the analog basins from Klemme's list of Class IICc basins. Therefore, you either have a basin similar in geology to the Class IICc analog basins, OR you may be missing some 
crucial geologic information about your basin and have possibly misclassified it. You may wish to recheck your basin classification before proceeding with a more detailed basin analysis. *

space DUO1 desc $/ *$ Evidence of a second type of two-cycle Tethyan basin */

ques $/ *$ DO YOU HAVE A BASIN WITH TWO MAJOR MORPHOLOGIC CYCLES OR SEQUENCES WHOSE FIRST CYCLE IS A RIFT AND RIFT-FILL ON AN ACCRETED ZONE, FOLLOWED BY A SECOND CYCLE OF A CIRCULAR, LOBATE, OR LINEAR SAG SEQUENCE, AND LOCATED INSIDE THE CENTRAL TETHYS WHERE CONVERGENT COLLISION FORMS TENSION AND WRENCH RIFT AND SAG CYCLES OF POST UPPER CRETACEOUS AGE */

expl /* I am trying to determine if your two-cycle basin has the exact cycle description and exact Tethyan location as described in the question. If the answer is yes to both parts of the question, answer YES. But if the answer is no to either part or you have more than two cycles, answer NO */yes RIGHT no TRI

space TRI desc $/ *$ Evidence of a three-cycle open Tethyan basin */

ques $l^{*}$ DO YOU HAVE A BASIN THAT HAS THREE MAJOR MORPHOLOGIC CYCLES OR SEQUENCES WHOSE FIRST CYCLE IS A PLATFORM WEDGE (OFTEN PARTIALLY ERODED) THAT ONLAPS ON THE CRATON, FOLLOWED BY A SECOND CYCLE OF RIFT AND RIFT-FILL, FOLLOWED BY A THIRD CYCLE OF A CIRCULAR, LOBATE, LINEAR SAG OR HALF SAG CYCLE AND SEQUENCE, LOCATION INSIDE CENTRAL TETHYS IN COASTAL ZONE OF INLAND SEAS AND GULFS WHERE THE SECOND CYCLE WITH UNIDIRECTIONAL RIFTING DOWNDROPS THE FIRST CYCLE CRATON ONLAP AND IS OVERLAIN BY A THIRD CYCLE LINEAR, HALF SAG SEQUENCE DIRECTED SEAWARD */

expl /* I am trying to determine if you have a three cycle basin, whether the cycles are described exactly as in the sequence listed in the question, and with a basin location inside central Tethys with a seaward tilt. If you can answer yes to all parts of the question, then answer YES, but if any part of the question must be answered no, then answer NO */yes RIGHT no DIFF

space DIFF desc /* Description of other multiple-cycle non-Tethyan basins */

inf $/^{*}$ You have described a multiple-cycle irregular symmetrical basin that you thought might be an open Tethyan basin. Your description, however, does not fit any of Klemme's multiple-cycle open Tethyan basins. You may have insufficient information for your Tethyan basin relative to the tectonic or depositional cycles, OR you may have a different class of multiple-cycle basins of the non-Tethyan type. I would recommend that you check other multiple-cycle basin models in this world basin classification system. */

\section{STOP}


APPENDIX H. -INFERENCE NET AND LISTING FOR CLASS IIIA-CRATON AND ACCRETED ZONE RIFT BASINS (MODEL 5), FILE NAME CAZR

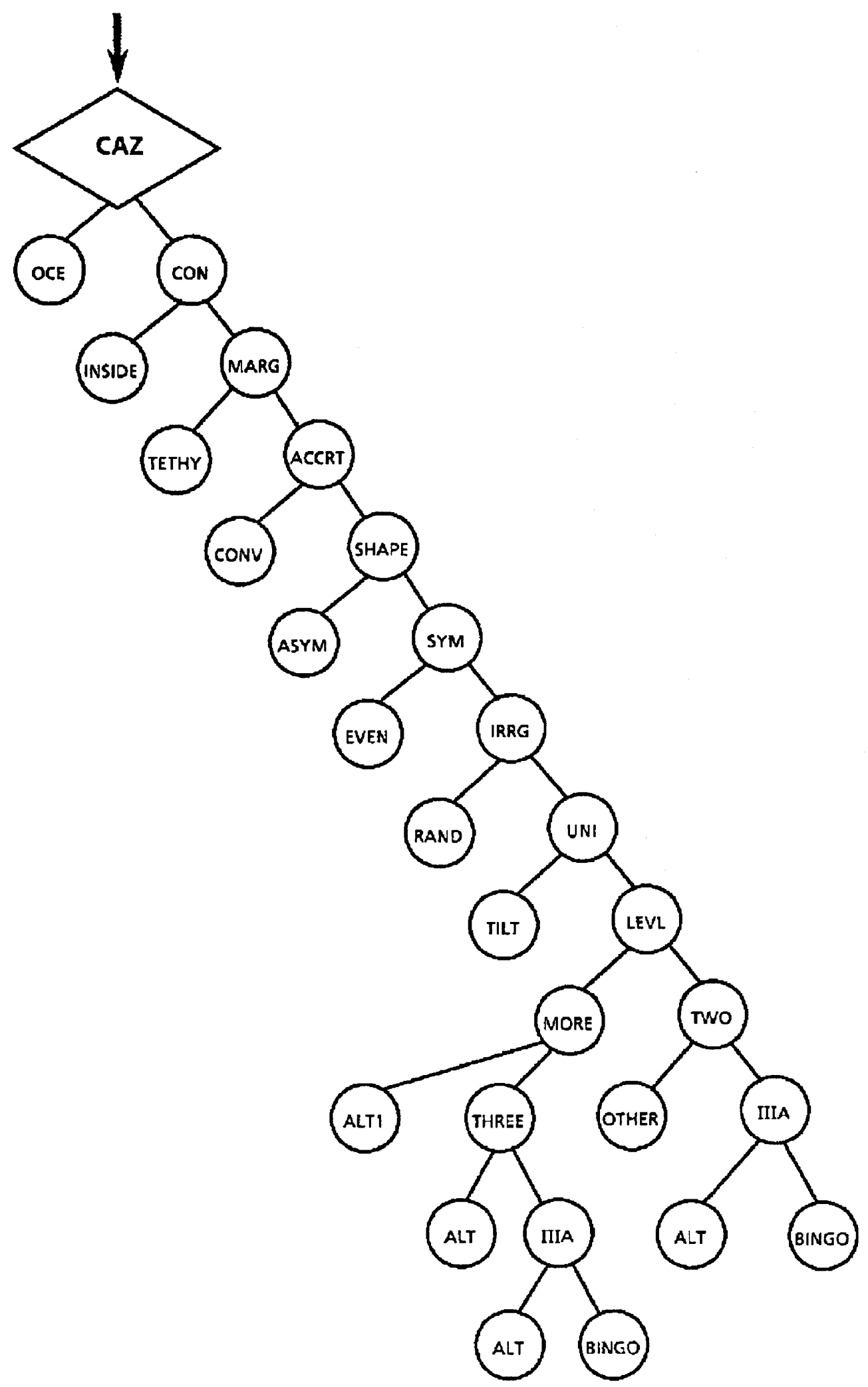

Inference net for Class IIIA-Craton and Accreted Zone Rift Basins (model 5), file name CAZR.

Appendix $\mathbf{H}$

55 
model CAZR

topspace CAZ

space CAZ desc $/ *$ Location of prospective basin relative to continental rather than oceanic crust */

ques $/ *$ IS YOUR BASIN LOCATED ON CONTINENTAL CRUST OR PRIMARILY CONTINENTAL CRUST (PLATES), AS OPPOSED TO BEING LOCATED PRIMARILY ON OCEANIC CRUST OR OCEANIC PLATES */

expl /* I am trying to determine if the position of the basin relative to the Earth's major crustal zones is predominantly on continental rather than on oceanic crust */ yes CON no OCE

announce $/^{*}$ The following questions are intended to aid in the classification of Continental Rifted Basins. */

space OCE desc /* Basins located on oceanic crust or partially on oceanic crust */

inf $/^{*}$ Your basin is an oceanic basin located primarily on oceanic crust. You will need to check the other basin models, particularly model 9 , in the world basin classification system. */

space CON desc /* Evidence of a continental basin located along the craton margin or accreted zone margin */

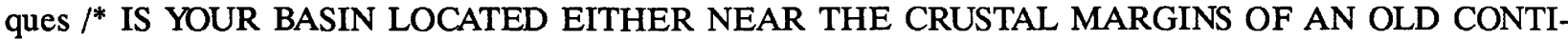
NENTAL PLATE OR ON AN ACCRETED ZONE MARGIN RATHER THAN ON AN INTERIOR CRATON OR AN OLD ACCRETED ZONE INTERIOR FROM THE MARGINS OF THE PLATE */

expl /* I am trying to determine whether your basin is found along an old cratonic plate margin or a cratonic accreted zone at the margins of a continental plate RATHER THAN on an interior continental plate or old accreted zone interior from the margins of the plate */ yes MARG no INSIDE

space INSIDE desc /* Description of a Craton-Accreted Margin Complex Basin */

inf $/^{*}$ You may have a continental multicycle basin of the Craton-Accreted Margin Complex type and described in this world basin classification system as a Class IIB basin, model 3. You may wish to check this model. */

space MARG desc /* Evidence of a non-Tethyan cratonic margin and/or Craton-Accreted Margin Complex Basin */ ques $/^{*}$ DO YOU HAVE A BASIN THAT IS A NON-TETHYAN CRATONIC MARGIN BASIN AND IS LOCATED ON AN ACCRETED ZONE AT THE MARGINS OF THE CRATON */

expl $/^{*}$ I am trying to determine if your basin is a non-Tethyan basin and is also located either on the margins of a cratonic plate or in a zone surrounding and accreted to the craton, such as that of Phanerozoic welding of displaced terranes, for example, rather than a Tethyan basin on an accreted zone */yes ACCRT no TETHY

space TETHY desc /* Description of a Tethyan basin model */

inf $/^{*}$ From the description of your basin you may have a continental multicycle basin of the Class II type and

the Crustal Collision Zone-Convergent Plate Margin Basin, IIC, model 4. Please check model 4 in this basin classification system. */

space ACCRT desc $/ *$ Evidence of an extension basin modified by local wrench compression */ ques $/ *$ DO YOU HAVE A BASIN WHICH EXHIBITS EXTENSION CHARACTERISTICS CAUSED BY DIVERGENCE WITH TENSION BLOCK FAULTING AND SUBSIDENCE */

expl $/^{*}$ I am trying to determine if you have a Craton-Accreted Margin Complex Basin that exhibits extension characteristics with possibly a rift-sag sequence */ yes SHAPE no CONV

space CONV desc /* Description of a Craton-Accreted Margin Complex Basin */

inf $/^{*}$ From the description of your basin you may have a Craton-Accreted Margin Complex Basin that is located within an area of convergent plate movement. Your basin may be either a Crustal Collision Zone-Convergent Plate Margin Basin of Class IIC, model 4, or a Rifted Convergent Margin Basin of Class IIIB, model 6. */

space SHAPE desc /* Evidence of a symmetrical elongate basin */ 
ques $/ *$ DO YOU HAVE AN ELONGATED BASIN THAT IS SMALL-TO-MODERATE IN SIZE AND ESSENTIALLY SYMMETRICAL IN PROFILE */

expl /* I am trying to determine whether your basin is essentially elongated in shape and symmetrical in profile */yes SYM no ASYM

space ASYM desc /* Description of an asymmetrical basin */

inf $/^{*}$ From the description of your basin you may have a Craton-Accreted Margin Complex Basin with possibly an asymmetrical profile. You may wish to check some of the other basin descriptions in Class II or Class III for classification. */

space SYM desc $/ *$ Evidence of an irregular symmetrical basin */

ques $l^{*}$ DO YOU HAVE A SYMMETRICAL BASIN WITH AN IRREGULAR SEDIMENTTO-BASEMENT CONTACT $* /$

expl /* I am trying to determine if your elongated, symmetrical basin has an irregular sediment-to-basement contact due to rift faulting and rift-fill */ yes IRRG no EVEN

space EVEN desc $/^{*}$ Description of a cratonic margin basin with a smooth symmetrical profile */

inf $/^{*}$ From the description of your basin you may have either a modified Craton Interior Basin of the Klemme

Class I, model 1, or you may have a Delta Basin of the Klemme Class IV, model 8. You should check these other basin models. */

space IRRG desc $/ *$ Evidence of a symmetrical, unidirectionally rifted basin */

ques $/ *$ DO YOU HAVE A SYMMETRICALLY ELONGATED BASIN WITH A UNIDIRECTIONALLY RIFTED BASEMENT WHERE SINGLE RIFTS OR LOCALLY MULTIPLE RIFTS ARE OVERLAIN BY A LINEAR SAG AS OPPOSED TO A BASIN WITH A RANDOM DIRECTIONALLY RIFTED BASEMENT AND BASEMENT FILL IS OVERLAIN BY A CIRCULAR TO LOBATE SAG */

expl /* I am trying to determine if you have a unidirectionally rifted basin overlain by a linear sag, as opposed to a randomly directional rifted basin overlain by a circular to lobate sag */yes UNI no RAND

space RAND desc /* Description of a Class IIB basin */

inf $/^{*}$ From the description of your basin you may have a Klemme Class IIB basin of the Continental Multicycle Craton-Accreted Margin Complex type. Please check basin model 3. */

space UNI desc $/^{*}$ Evidence of an irregular, symmetrical basin with a horizontal profile */

ques $/ *$ DOES YOUR IRREGULAR, SYMMETRICAL BASIN HAVE AN ESSENTIALLY HORIZON-

TAL PROFILE '(LEVEL) AS OPPOSED TO A TILTED PROFILE *

expl $/^{*}$ I am trying to determine whether you have an essentially level basin as opposed to a basin that has been tilted seaward */ yes LEVL no TILT

space TILT desc $/ *$ Description of a Class IIIC basin */

$\inf /^{*}$ From your basin description you may have a symmetrical, irregular basin tilted seaward that is of the Class IIIC type. Please check basin model 7. */

space TWO desc $/ *$ Evidence of a two-cycle, craton and accreted zone, rift basin */

ques $/ *$ DO YOU HAVE A BASIN WITH TWO MAJOR MORPHOLOGIC CYCLES OR SEQUENCES, WHOSE FIRST CYCLE IS USUALLY A WELL-DEVELOPED SINGLE RIFT OR A UNIDIRECTIONAL AND PARALLEL SET OF CLOSELY SPACED RIFTS AND GRABENS, OVERLAIN BY A SECOND CYCLE LINEAR SAG PARALLEL TO THE UNDERLYING RIFTS */

expl /* I am trying to determine if your two-cycle basin has the exact sequence as described in the question, as opposed to a two-cycle basin with a different sequence described for a two-cycle basin */ yes IIIA no OTHER 
space LEVL desc /* Evidence of a two-cycle basin */

ques $/ *$ DO YOU HAVE A BASIN WITH EXACTLY TWO CYCLES AS OPPOSED TO A BASIN WITH MORE THAN TWO MAJOR MORPHOLOGIC CYCLES OR SEQUENCES */

expl /* I am trying to determine if you have a two cycle basin rather than a basin with three (or more) cycles */yes TWO no MORE

space IIIA desc /* Evidence of a Class IIIA basin */

announce $/^{*}$ Congratulations! You have successfully described a two-cycle, or a three-cycle elongated symmetrical, irregular, rifted basin of the Klemme Class IIIA type: a Craton and Accreted Zone Rift Basin. The following questions are intended to aid in evaluating this basin more fully. */

ques $/ *$ DO YOU HAVE A BASIN SIMILAR TO, OR ONE OF THE FOLLOWING ANALOG BASINS THAT HAVE BEEN CLASSIFIED BY KLEMME AS CLASS IIIA: ALTAR, BAY OF FUNDY, GRAND BANKS, GUAYMAS, MID-GREENLAND, OLE, JONES-LANCASTER, RIO GRANDE, SNAKE RIVER, GULF OF ST. LAWRENCE, VICTORIA STRAIT, COLORADO (ARGENTINA), JATOBA, SALADO, SAN JORGE, TACATU, TUCANO, BENUE, DOBA, FARAFRA, GAO, KAOUAR, LAKE ALBERT, LAKE EDWARD, LAKE KIVU, LAKE NYASA, LAKE RUDOLPH, LAKE TANGANYIKA, WEST RED SEA, SIRTE, GULF OF SIRTE, SUDAN, GULF OF SUEZ, TAFASSASSET, TALAK, TAMATAVE, AQUITAINE, BALEARIC, BRESSE, CANTABRIAN, CELTIC, EBRO FAN, HEBRIDES, HAMMERFEST, MIDLANDS, MINCH, POLISH, NORTH SEA, PORCUPINE, RHINE, RHONE DELTA, WEST SHETLANDS, TROMSO, WESTERN APPROACHES, DEAD SEA, FARTAK, EAST RED SEA, ADAVALE, ANAMBAS, ARCKARINGA, BANGKOK, BASS, BOHAI GULF, BOWEN, CAMBAY, CAMPBELL, CANTERBURY, CARNARVON, CHAIDAMUS, CHAO PHRAYA, COOPER, DANDARAGON, ERLIAN, FANG, FITZROY, GALILEE, GIPPSLAND, GODAVARI, GREAT SOUTH, HAILAR, HUABEI, JIANGHAN, JIUQUAN, KOREA BAY, LAURA, MALAY, NANYANG, NATUNA, PEDIRKA, PENYU, PERTH, PUKAKI, PUKAKI EMBAYMENT, SHANGHAI, SONGLIAO, SOUTH YELLOW SEA, STYX, SURAT, SYDNEY, NORTH TARIM, THAI, TULUFAN, ZHUNGEER, AGINSKIY, BALKHASH, UPPER BUREYA, CHUYI, DNEPR-DONETS, GOBI, IL-YI, INDIGIRKA-ZYRYANKA, KHAN KAY, LAPTEV, LAKE BAIKAL, PRIPYAT, SHANJIANG, TASHKENTUDA, ZAYSAN, ZEYA-BUREYA, EAST AND WEST ROSS */

expl $/ *$ I am trying to determine if you have one of the basins or a similar basin as the analog basin-types described by Klemme as Class IIIA and listed in the question */yes BINGO no ALT

space OTHER desc $/ *$ Description of other two-cycle basins */

inf $/^{*}$ If you do not have the exact description for the two major morphologic cycles and in the same sequence, you probably have a two-cycle basin of a different class. You may have one of the following Klemme classes: IIB, IIC, IIIB, or IIIC (models 3, 4, 6, and 7). */

space BINGO desc /* Description of a classic Class IIIA basin */

inf $/ *$ Congratulations! You have described a basin which fits the description of the Klemme Class III Continental Rifted Basins of the IIIA type for Craton and Accreted Zone Rift Basins and you have matched the basin with one classified by Klemme as a IIIA. You are now ready to do a more detailed basin analysis on your basin. */

space ALT desc /* Description of other basin analogs or other basin models */

inf $/ *$ From the description of your basin it would appear that you have a Class IIIA type basin of the continental rifted craton and accreted zone margins. However, you have not selected one of Klemme's classic analog basins as being similar to your basin. There are lists of analog basins in the published literature that you may wish to check for this basin class. You may also wish to check the other basin models, especially for the Class IIB and IIC varieties (models 3 and 4). ${ }^{*}$ / 
space MORE desc $/ *$ Evidence of a three-cycle Class IIIA basin */

ques $/^{*}$ DO YOU HAVE A BASIN WITH THREE MAJOR MORPHOLOGIC CYCLES OR SEQUENCES, WHOSE FIRST CYCLE IS A PLATFORM WEDGE (OFTEN PARTIALLY ERODED) THAT ONLAPS THE CRATON, OVERLAIN BY A SECOND CYCLE OF WELL-DEVELOPED UNIDIRECTIONAL RIFTS OR A PARALLEL SET OF CLOSELY SPACED RIFTS AND GRABENS AND RIFT-FILL, OVERLAIN IN TURN BY THE THIRD CYCLE OF A LINEAR SAG PARALLEL TO RIFTING */

expl /* I am trying to determine if you have a basin with three major morphologic cycles or sequences that can be described exactly and in the same order as listed in the question. If you have more than three cycles or if your three cycles are not as described in the question, then answer NO */yes THREE no ALT1

space ALT1 desc /* Description of other basin models */

inf $/^{*}$ According to your basin description you appear to have a Class IIIA basin. However, your description of a three-cycle basin does not fit the Klemme Class IIIA model for a three-cycle basin. You may have a basin of either the Klemme Class IIA, IIB, or IIC models or you might have a Class IIIC model basin. Please check basin models $2,3,4$, and $7 . * /$

space THREE desc $/ *$ Evidence of a three-cycle Class IIIA basin */

announce $/^{*}$ Congratulations! You have described a three-cycle basin of the Klemme Class III Continental Rifted Basin of the IIIA Craton and Accreted Zone Rift variety. The following questions are intended to evaluate your basin more fully */

ques $/ *$ WOULD YOU LIKE TO CHECK THE LIST OF ANALOG BASINS CLASSIFIED BY KLEMME AS CLASS IIIA BASINS FOR A MATCH WITH YOUR BASIN */

expl $/^{*}$ I am trying to determine if you have a basin similar to the list of analog basins or one of the analog basins in the list taken from Klemme's as described in the question */yes IIIA no ALT 
APPENDIX I. -INFERENCE NET AND LISTING FOR CLASS IIIB-RIFTED CONVERGENT MARGIN BASINS (MODEL 6), FILE NAME RCM

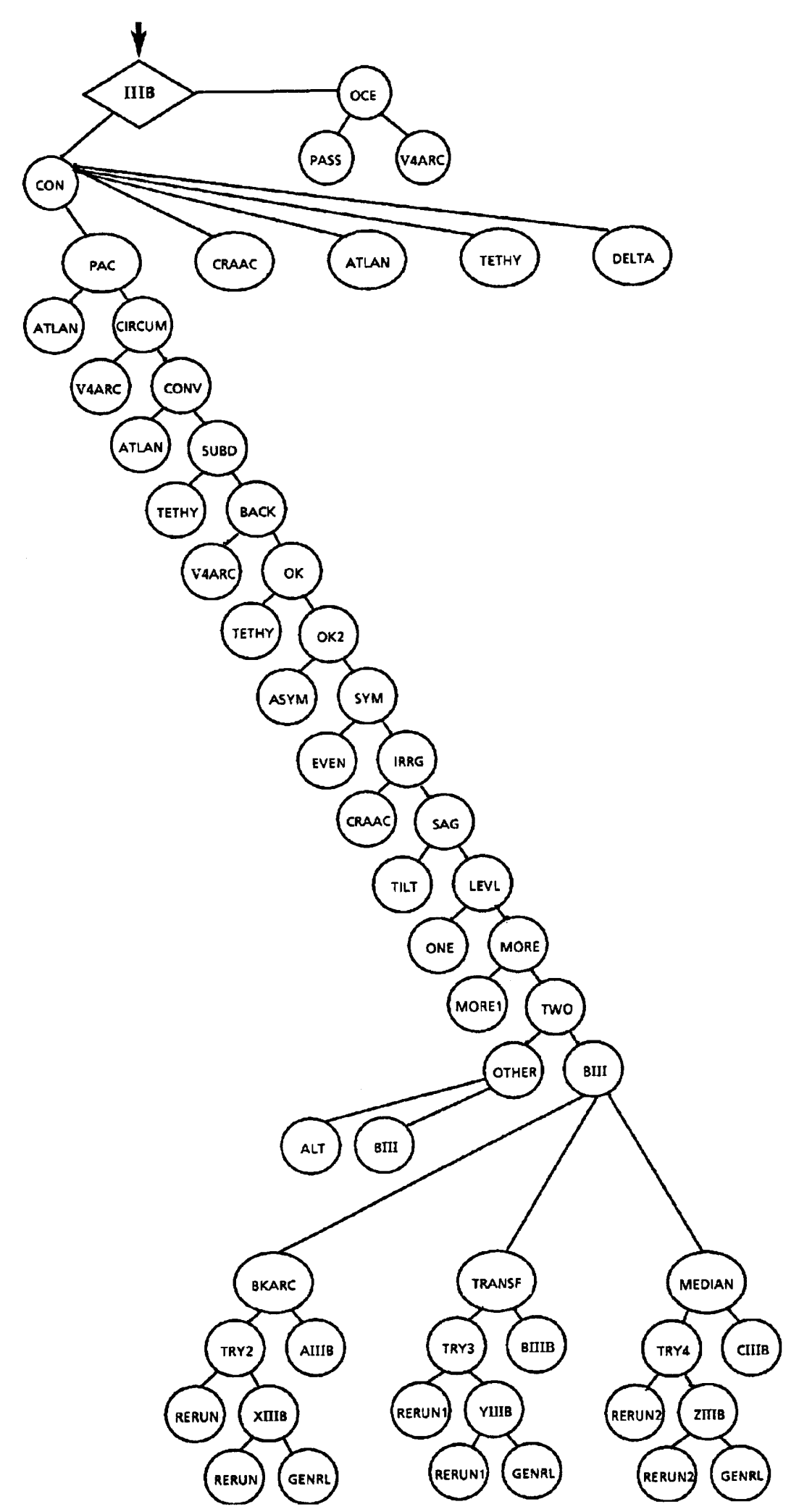

Inference net for Class IIIB-Rifted Convergent Margin Basins (model 6), file name RCM.

60 The muPETROL Expert System for Classifying World Sedimentary Basins 
model RCM

topspace IIIB

space IIIB desc $/ *$ Location of prospective basin relative to continental rather than oceanic crust */

ques $/ *$ IS YOUR BASIN LOCATED ON CONTINENTAL CRUST OR PRIMARILY CONTINENTAL CRUST (PLATES), AS OPPOSED TO BEING LOCATED PRIMARILY ON OCEANIC CRUST OR OCEANIC PLATES */

expl /* I am trying to determine the position of the basin relative to the Earth's major crustal zones, that is, whether the basin is primarily on continental crust or continental margins as opposed to being located on oceanic crust. */yes CON no OCE

announce $/^{*}$ The following is intended to aid in the classification of Continental Rifted Margin Basins */

space OCE desc $/ *$ Evidence of basins located on oceanic crust or primarily on oceanic crust */

ques $/ *$ DO YOU HAVE AN OFFSHORE BASIN LOCATED ENTIRELY ON OCEANIC CRUST AS OPPOSED TO A BASIN LOCATED PARTIALLY ON OCEANIC AND PARTIALLY ON CONTINENTAL CRUST *I

expl /* I am trying to determine if you have an offshore or marginal basin that is located completely on oceanic crust */yes V4ARC no PASS

space V4ARC desc $/ *$ Description of a Class V Forearc Basin */

inf $/^{*}$ From the description of your basin you may have a forearc basin of the Klemme Class $V$ type and you should check basin model 9 in this world basin classification system. */

space PASS desc /* Description of a Class IIIC Rifted Passive Margin Basin *

inf $l^{*}$ From the description of your basin you may have an Atlantic-type rifted passive margin basin of the Klemme Class IIIC, model 7, in this basin classification system. */

space CON desc $/ *$ Description of Continental Margin Basins */

announce $/^{*}$ The following is intended to aid in the description of the five classes of continental margin basins

$* /$

choices /* PAC ATLAN CRAAC TETHY DELTA */

space ATLAN desc /* Description of IIIC Atlantic, Indian and Arctic Ocean Margin Basins */

noun-phrase /* IIIC. Atlantic-Indian-Arctic Ocean Margin Basins */

inf $/^{*}$ If you made this selection, you probably have a coastal basin located on the Atlantic, Indian, or Arctic Ocean continental margins. If true, you may have a Klemme Class IIIC basin and should check basin model 7 in this basin classification system. If you have an older interior craton margin basin, you may have a Klemme Class IIA or IIB basin or possibly a modified Class I basin and you should check models 1,2 , and 3. */

space CRAAC desc /* Description of older cratonic margin or pericratonic margin basins */

noun-phrase /* Older Cratonic Margin or Pericratonic Margin Basins */

inf $/^{*}$ If you made this selection for continental margin basins, you probably have a basin of the Klemme Class IIA, IIB, or IIIA class and you should check basin models 2,3 , and 5 in this world basin classification system. */

space TETHY desc $/ *$ Description of a Class IIC Tethyan-type basin */

noun-phrase /* IIC. Tethyan-type basin in a Crustal Collision Zone */

inf $/^{*}$ If you made this selection you probably have a basin that is located in the old Tethyan seaways and is of the Klemme Class IIC in a Crustal Collision Zone-Convergent Plate Margin that downwarps into a small ocean basin. Class IIC has three subdivisions for the closed, trough, and open basin varieties and you should check the descriptions for the Class IIC, model 4 , basins in this classification system. ${ }^{*}$ / 
space DELTA desc $/ *$ Description of a Class IV Delta Depocenter Basin */

noun-phrase /* IV. Delta Depocenter Basin */

inf $/^{*}$ If you made this selection, you probably have a continental margin basin that has been modified by a delta depocenter of Tertiary to Recent age. If so, you probably have a Klemme Class IV Delta Basin and you should check the description of basin model 8 given in this world basin classification system. */

space PAC desc /* Evidence of Class IIIB circum-Pacific-type basins */

noun-phrase $/ *$ IIIB. Circum-Pacific-type basins */

ques $1^{*}$ DO YOU HAVE A BASIN THAT IS LOCATED IN BASINAL AREAS BORDERING THE PACIFIC OCEAN AS OPPOSED TO LOCATIONS BORDERING THE ATLANTIC, INDIAN, OR ARCTIC OCEAN */

expl $/^{*} \mathrm{I}$ am trying to determine if your basin is located along the continental margins of the circum-Pacific as opposed to a location on the continental margins of the Atlantic, Indian, or Arctic Ocean */yes

CIRCUM no ATLAN

space CIRCUM desc $/ *$ Evidence of coastal zone margin basins rather than island forearcs */

ques $l^{*}$ IS YOUR BASIN LOCATED ALONG THE PACIFIC CONTINENTAL MARGINS THAT EXTEND FROM THE COASTAL ZONES AND ISLAND ARCS AND POSSIBLY EXTEND BACK INTO THE BORDERING MOUNTAINS ALONG THE COASTAL MARGINS AS OPPOSED TO BASINS LOCATED IN ISLAND FOREARC AREAS */

expl /* I am trying to determine if your basin is located along the Pacific continental margins in coastal zones and/or back island arcs, and if it may extend back into mountainous areas that border the coastal areas, as opposed to basins located in island forearc areas or completely on oceanic crust */yes CONV no V4ARC

space CONV desc $/ *$ Evidence of a convergent margin basin */

ques ${ }^{*}$ IS YOUR BASIN LOCATED ALONG A COASTAL ZONE MARGIN IN WHAT HAVE BEEN TERMED CONVERGENT AND TRANSFORM MARGINS */

expl /* I am trying to determine if your basin is located along a major convergent and/or transform coastal margin zone as opposed to a location on both an accreted zone crust and/or oceanic crust where local divergence has occurred */yes SUBD no ATLAN

space SUBD desc $/ *$ Evidence of a subduction zone basin $* /$

ques ${ }^{*}$ DO YOU HAVE A POST LATE CRETACEOUS BASIN LOCATED AT THE CONVERGENCE OF TWO PLATES (OCEANIC AND CONTINENTAL) WITH THE SUBDUCTION OF THE OCEANIC PLATE MARGIN BY EITHER CONSUMPTION OR TRANSFORM COLLISION OF THE ACCRETED CRUST FORMING A TRENCH AND ISLAND ARCS */

expl /* I am trying to determine if your basin is located at the convergence of two plates with the downbending of the oceanic plate under the overriding continental plate, or a cold oceanic plate sinking under the upper plate, as opposed to the convergence of two continental plates or two oceanic plates */yes BACK no TETHY

space BACK desc $/^{*}$ Evidence of back arc or transform basins */

ques $/ *$ DO YOU HAVE A BASIN THAT IS LOCATED ON THE CONTINENTAL PLATE AS A TENSION, WRENCH, OR SHEAR BASIN AND THAT LIES BEHIND THE ISLAND ARC OR A VOLCANIC ISLAND ARC */

expl /* I am trying to determine if you have a post Late Cretaceous basin described as a back-arc or transform basin caused due to tension as a wrench or shear basin, as opposed to an oceanic trench or forearc basin */yes OK no V4ARC

space OK desc $/^{*}$ Tentative evidence of a Class IIIB basin */

announce $/^{*}$ So far, so good! From the description of your basin it appears that you may have a rifted 
convergent margin basin with oceanic consumption, of the Klemme Class IIIB type. However, the following questions will aid in defining further the varieties of basins in this class. */

ques $/ *$ IS YOUR BASIN LOCATED IN SOUTHEASTERN ASIA AT THE EASTERN END OF THE CENTRAL TETHYS AND A PART OF AN OCEANIC SUBDUCTION ZONE AS RELATED TO THE CIRCUM-PACIFIC TYPE BASINS, AS OPPOSED TO THE OTHER TETHYAN BASINS NOT RELATED TO THE CIRCUM-PACIFIC TYPE */

expl /* I am trying to determine if you have a basin that may be located in the eastern end of the Central Tethys but is also located on an oceanic subduction zone in southeastern Asia, as opposed to being located in any other part of the Tethyan seaways and not in an area of a circum-Pacific subduction zone */yes OK2 no TETHY

space OK2 desc $/ *$ Evidence of a symmetrical basin */

ques /* DO YOU HAVE A BASIN WHOSE PROFILE OR CROSS SECTION ACROSS THE BASIN AT THE SEDIMENT-BASEMENT CONTACT IS ESSENTIALLY SYMMETRICAL */

$\operatorname{expl} /^{*}$ I am trying to determine if the profile of your basin is essentially symmetrical in shape as opposed to an asymmetrical basin */ yes SYM no ASYM

space ASYM desc /* Description of asymmetrical basin classes */

inf $l^{*}$ From the description of your basin you appear to have an asymmetrically shaped basin which could be in any one of the following basin classes (in the likely order in which you have answered your earlier questions): first Class V, or possibly Class IV, or in one of the three Class II basins. You should check basin models 9 and 8, and then 2,3 , and 4 in this order. $*$ I

space SYM desc $/ *$ Evidence of a symmetrical, irregular basin */

ques ${ }^{*}$ DO YOU HAVE A SYMMETRICAL BASIN WITH AN IRREGULAR BASEMENT CONTACT DUE TO UNIDIRECTIONAL RIFTING OF THE ACCRETED BASEMENT */

expl $/^{*}$ I am trying to determine if your symmetrical basin has an irregular basement contact due to unidirectional rifting by block faulting and differential plate movement, as opposed to a smooth or even basement profile with little or no rifting or block faulting */ yes IRRG no EVEN

space EVEN desc $/ *$ Description of a symmetrical basin with a smooth or even basement contact */

inf $/^{*}$ From the description of your basin it would seem that the accreted basement has not been affected by any rifting or block faulting, or you may be missing important information that would indicate the basin should be rifted at depth. You may either rerun Class IIIB, model 6, and assume there is a rifted basement contact or check other basin models (1 through 4 ) in Klemme Class I and II. */

space IRRG desc $/ *$ Evidence of a symmetrical, irregular basin overlain by a linear sag */

ques $/ *$ IS YOUR SYMMETRICAL, IRREGULAR BASIN (IRREGULAR DUE TO A UNIDIRECTIONALLY RIFTED ACCRETED BASEMENT) OVERLAIN BY A LINEAR SAG PARALLEL TO THE RIFTING TREND */

expl /* I am trying to determine whether your symmetrical basin, located on an accreted zone margin where convergent or transform plate motion due to subduction occurs and where unidirectional rifting has occurred in the accreted basement, is overlain by a linear sag which lies parallel to the trend of rifting */ yes SAG no CRAAC

space SAG desc $/ *$ Evidence of a basin with a level or horizontal basin profile */

ques ${ }^{*}$ DOES YOUR SYMMETRICAL, IRREGULAR BASIN HAVE A LEVEL OR HORIZONTAL PROFILE AS OPPOSED TO A TILTED BASIN PROFILE */

expl $/^{*}$ I am trying to determine if your basin is in a level or horizontal position as opposed to being tilted seaward */yes LEVL no TILT

space TILT desc /* Description of other basin models with a tilted basin profile */

inf $/^{*}$ Given that you have a basin that is tilted seaward, it would appear that you may have a basin that is 
better described by another basin model. It is quite possible that you may have one of the following basin classes: any one of the three Class II basins (models 2, 3, and 4), or a Class IIIC basin (model 7), or a IIIB basin (model 6) that has been modified by a delta depocenter and classed as a type IV basin (model 8). You may want to check these other basin models or recheck to see if you are missing important data on the description of your basin. ${ }^{*}$

space LEVL desc /* Evidence of a two-cycle basin */

ques $/ *$ DO YOU HAVE A BASIN THAT HAS AT LEAST TWO MAJOR MORPHOLOGIC CYCLES OR SEQUENCES AS OPPOSED TO A SINGLE CYCLE BASIN */

expl $/^{*}$ I am trying to determine if your basin has more than a single major morphologic cycle or sequence */yes MORE no ONE

space ONE desc $/ *$ Description of single-cycle basins */

inf $/^{*}$ If you have a single major morphologic cycle or sequence in your basin, you may have any one of the following class basins: a Class I basin (model 1), a Class IIB basin (model 3), a Class IV (model 8), or a Class V basin (model 9). */

space MORE desc /* Evidence of a two-cycle basin */

ques $/ *$ DO YOU HAVE A BASIN WITH EXACTLY TWO MAJOR MORPHOLOGIC CYCLES OR SEQUENCES AS OPPOSED TO A BASIN WITH MORE THAN TWO CYCLES */

expl /* I am trying to determine if you have exactly two cycles in your basin as opposed to more than a two cycle basin */ yes TWO no MORE1

space MORE1 desc /* Description of a basin with three or more morphologic cycles */

inf $/ *$ If you have a basin with definitely more than two morphologic cycles, then you probably have one of the following basins: any one of the three Class II basins (models 2, 3, and 4), or a Class IIIA (model 5) or IIIC basin (model 7). Please check these other basin models. $*$ /

space TWO desc $/ *$ Evidence of the first of the two-cycle basins */

ques $/ *$ DO YOU HAVE A BASIN LOCATED IN THE CIRCUM-PACIFIC AREA AND ALONG CONVERGENT AND TRANSFORM MARGINS WHERE SUBDUCTION OF PLATE MARGINS OCCURS AND WITH TWO MAJOR MORPHOLOGIC CYCLES THAT CAN BE DESCRIBED AS FOLLOWS: THE FIRST CYCLE CONSISTS OF A RIFT AND RIFT-FILL ON AN ACCRETED MARGIN ZONE, OVERLAIN BY A LINEAR SAG SEQUENCE IN SMALL-TO-MODERATE-SIZED POST LATE CRETACEOUS BASINS $*$

expl $/^{*}$ I am trying to determine if your basin has the exact two-cycle sequence as described in the question and is located as a circum-Pacific subduction zone basin. If your two-cycle basin sequence is exactly as given in the question, answer YES, otherwise answer NO */ yes BIII no OTHER

space BIII desc $/ *$ Evidence of two-cycle Class IIIB basins */

announce $/ *$ Congratulations! You have described a circum-Pacific subduction zone basin with two cycles that fits the description of a Klemme Class IIIB basin, entitled a Rifted Convergent Margin (Oceanic Consumption) Basin. The following is intended to aid in defining the three basin types that occur in Class IIIB. */

choices $/ *$ BKARC TRANSF MEDIAN */

space OTHER desc $/ *$ Evidence of other two-cycle basins */

ques /* DO YOU HAVE A CENTRAL TETHYS BASIN THAT IS LOCATED AT THE EASTERN END OF THE TETHYS AND LIES IN THE FAR EAST ASIAN SECTOR AND THUS IS A PART OF THE CIRCUM-PACIFIC SUBDUCTION MARGIN ZONE, AND THAT HAS TWO MAJOR MORPHOLOGIC CYCLES AS FOLLOWS: THE FIRST CYCLE IS A TENSION AND WRENCH RIFT AND RIFT-FILL ON AN ACCRETED ZONE, OVERLAIN BY A SECOND LINEAR SAG CYCLE OF POST LATE CRETACEOUS AGE */ 
expl /* I am trying to determine if you have a two-cycle basin described in the exact sequence as given in the question, and if the basin is located at the eastern end of the Central Tethys in the Far East Asian sector, near-bordering the circum-Pacific subduction margin zone. */ yes BIII no ALT

space ALT desc /* Description of other two-cycle basins */

inf $/^{*}$ From the description of your basin you have a two-cycle basin, but it does not fit the descriptions of Klemme's Class IIIB basins. Therefore you may have a two-cycle basin of a different basin class description. You should check the following basin classes: all three of the Class II basins (models 2, 3, and 4), and the Class IIIA (model 5) and IIIC (model 7) basins. */

space BKARC desc $/ *$ Evidence of a Class IIIB Rifted Convergent Margin Basin (type a. Back Arc Basin) */

noun-phrase /* IIIBa. Rifted Convergent Margin-Back Arc Basins *I

ques $/ *$ DO YOU HAVE ANY ONE OF THE FOLLOWING BASINS OR A BASIN SIMILAR TO THESE ANALOG BASINS: BRISTOL BAY, AKITA, GRENADA, BALI, EAST AND WEST BANKA, BARITO, BAWEAN, BILITON, EAST CHINA, EAST AND WEST JAVA, MAHAKAM, NIGATA, OKINAWA, SOUTH PALAWAN, NORTH-SOUTH-AND CENTRAL SUMATRA, SUNDA, TAIWAN, TARAKAN, TOYAMA, OR TSUSHIMA BASIN */

expl $/^{*}$ I am trying to determine if your basin is one of the basins listed in the question or a basin with a similar geologic description that is of the Klemme Class IIIBa variety */yes AIIIB no TRY2

space TRY2 desc /* Description of Class IIIBb or IIIBc basins */

announce $/^{*}$ If you do not have any of the analog basins listed in the previous question or your basin does not appear to have a similar geology as these basins, then you may have a IIIBb (Transform Rifted Convergent Margin Basin), or a IIIBC (Median Rifted Convergent Margin Basin). You should rerun this model and pick one or the other of these choices for an analog basin fit. OR you may have already checked these other two options. IF so, then you should check the general list of IIIB basins as classified by Klemme without the further distinction of the basins being an $\mathrm{a}, \mathrm{b}$, or $\mathrm{c}$ variety. ${ }^{*} /$

ques ${ }^{*}$ WOULD YOU LIKE TO CHECK THE LIST OF CLASS IIIB BASINS AS CLASSIFIED BY KLEMME, BUT IN WHICH HE DOES NOT DISTINGUISH BETWEEN THE $a, b$, AND c VARIETIES */

expl /* In the AAPG publication of 1984 Klemme has four groups of Class IIIB basins listed among the world basins. They are: 1. IIIBa Back Arc, 2. IIIBb Transform, 3. IIIBc Median, and 4. IIIB Rifted Convergent Margin basins that are not distinguished as to the three varieties listed above as $a, b$, and c. */ yes XIIIB no RERUN

space RERUN desc $/^{*}$ Evidence of another class of basin */

inf $/^{*}$ It would appear that you do not have a Class IIIBa basin or at least none of the basins listed by Klemme as a IIIBa basin. For whatever reason, you have chosen not to check Klemme's list of basins that he classified only as Class IIIB basins, OR you have checked the list of Class IIIB basins and do not have any of these analog basins. Therefore, I would recommend that you recheck the geologic data on your basin and rerun this model and pick either the Class IIIBb or IIIBc variety of basin for a basin check. Good Luck! */

space XIIIB desc $/ *$ Description of a general Class IIIB basin */

ques $/ *$ DO YOU HAVE ONE OF THE FOLLOWING BASINS OR A SIMILAR BASIN THAT KLEMME HAS CLASSIFIED ONLY AS A CLASS IIIB BASIN WITHOUT DISTINGUISHING BETWEEN ANY ONE OF THE THREE VARIETIES a, b, OR c: BETHEL, COPPER RIVER, HOLITNA, MINCHUMINA, ST. MATTHEW, LOWER, MIDDLE, AND UPPER TANANA, YUKON/KANDIK, BURDWOOD BANK, JAMAICA EAST, PUERTO RICO, SOUTH GEORGIA, ALBORAN, DASHT-I-LUT, DJAZ MURIAN, TABRIZ, BEIBU GULF, CAGAYAN, CHANGDU, CHUXIONG, DANJO, HALMAHERA, HEIHE, HYMALAYA, LUZON, MADAN, MAE SOT, MOROTAI, NORTH AND SOUTH NORFOLK, SOLANDER, SPRATLY, SULU, ALEUTIAN, ALEUTIAN TRENCH, EAST SIBERIA, KHATYRKA, KOMANDARSKY, OR MOCHIGMEN */

expl /* If you do not have a Class IIIBa basin, you should check Klemme's list of Class IIIB basins that he has classified only by the basin's class and did not indicate which of the three basin varieties such as a, b, or c they 
space GENRL desc /* Evidence of a Class IIIB basin analog */

inf $/^{*}$ Congratulations! You have successfully matched your Class IIIB basin with one of the basins classified by Klemme as a Class IIIB basin without distinguishing it as any one of the three specific varieties: a, b, or c. You may recheck your geologic data and consider rerunning this model again for another check. HOWEVER, I think that you have analyzed the basin classification sufficiently and are ready to make a more detailed analysis of your basin. Good Luck! */

space AIIIB desc /* Description of a Class IIIBa basin */

inf $/ *$ Congratulations! You have picked an analog basin that fits Klemme's description of a Class IIIBa (type a. Rifted Convergent Margin-Back Arc Basin). You are now ready to make a more detailed analysis of your basin. *I

space TRANSF desc $/ *$ Evidence of a Class IIIB Rifted Convergent Margin Basin (type b. Transform Basin) $* /$ noun-phrase $/ *$ IIIBb. Rifted Convergent Margin-Transform Basin */

ques $/ *$ DO YOU HAVE ONE OF THE FOLLOWING BASINS OR A BASIN SIMILAR IN GEOLOGY TO ANY ONE OF THESE ANALOG BASINS: BODEGA, CENTRAL COASTAL, CHANNEL ISLANDS, COOK INLET, EEL RIVER, ENSENADA, LA JOLLA FAN, LOS ANGELES, NAVARIN, NAVY FAN, PURISIMA, QUEEN CHARLOTTE, SACRAMENTO-SAN JOAQUIN, SALINAS (CALIFORNIA), SANTA MARIA, ST. GEORGE, VENTURA, VISCAINO, ANA MARIA, BATO BANO, BONAIRE, CARIACO, CAUTO, CAYMAN, CHIRIQUI, CIBAO, COCHINOS, CENTRAL CUBA, FALCON, GUAJIRA, GULF OF GUAYAQUIL, HAITIAN-DOMINICAN, LOS ROQUES, TALARA, TRINIDAD-TOBAGO, ULUA, GULF OF VENEZUELA, BICOL, NORTH-SOUTH BURMA, CAMPBELL, CANTERBURY, COTA BATO, DAVAO, GREAT SOUTH, HAWKES BAY, ILOILOI, ISHIKARI-HIDAKA, KAPUAS, MEERVLAKTE, MELAWI, NORTHLAND, PUKAKI AND PUKAKI EMBAYMENT, RAMU, SEPIK, SIARGAO, TESHIO, TARANAKI, TOKACHI, VISAYAN, WAIKATO, WANGANUI, WESTLAND, WEWAK, ANADYR, WEST AND CENTRAL KAMCHATKA, PARAPOL, PENZHINA, NORTH SAKHALIN, AND TATARSKY BASIN */

expl $/^{*}$ I am trying to determine if you have any one of the listed Class IIIBb Klemme basins or a basin similar to any one of these analog basins */ yes BIIIB no TRY3

space TRY3 desc $/ *$ Description of either a Class IIIBa or IIIBc type basin */

announce $/^{*}$ If you do not have any one of the basins listed in the previous question or any basin with a similar geology, then you may have either a Klemme Class IIIBa or IIIBc type of basin. You should rerun this Klemme Class IIIB basin model and select either the Class IIIBa (Rifted Convergent Margin-Back Arc Basin) or the Class IIIBc (Rifted Convergent Margin-Median Basin). OR you may have already checked these other two options. IF so, then you should check the general list of Class IIIB basins as classified by Klemme without the further distinction of the basins being variety $a, b$, or $c . * /$

ques ${ }^{*}$ WOULD YOU LIKE TO CHECK THE LIST OF CLASS IIIB BASINS AS CLASSIFIED BY KLEMME, BUT IN WHICH HE DOES NOT DISTINGUISH BETWEEN THE a, b, AND c VARIETIES */

expl $/ *$ In the AAPG publication of 1984 Klemme has four groups of Class IIIB basins listed amoung the world basins. They are: 1. IIIBa Back Arc, 2. IIIBb Transform, 3. IIIBc Median, and 4. IIIB Rifted Convergent Margin basins that are not distinguished as to the three varieties listed above as a, b, and c. */yes YIIIB no RERUN1

space RERUN1 desc /* Evidence of another class of basin */

inf $/^{*}$ It would appear that you do not have a Class IIIBb basin or at least none of the basins listed by Klemme as a IIIBb basin. For whatever reason, you have chosen not to check Klemme's list of basins that he classified only as Class IIIB basins, OR you have checked the list of Class IIIB basins and do not have any of these analog basins. Therefore, I would recommend that you recheck the geologic data on your basin and rerun this model 
and pick either the Class IIIBa or IIIBc variety of basin for a basin check. Good Luck! */

space YIIIB desc $/ *$ Description of a general Class IIIB basin */

ques ${ }^{*}$ DO YOU HAVE ONE OF THE FOLLOWING BASINS OR A SIMILAR BASIN THAT KLEMME HAS ONLY CLASSIFIED AS A CLASS IIIB BASIN WITHOUT DISTINGUISHING BETWEEN ANY ONE OF THE THREE VARIETIES a, b, OR c: BETHEL, COPPER RIVER, HOLITNA, MINCHUMINA, ST. MATTHEW, LOWER, MIDDLE, AND UPPER TANANA, YUKON/KANDIK, BURDWOOD BANK, JAMAICA EAST, PUERTO RICO, SOUTH GEORGIA, ALBORAN, DASHT-I-LUT, DJAZ MURIAN, TABRIZ, BEIBU GULF, CAGAYAN, CHANGDU, CHUXIONG, DANJO, HALMAHERA, HEIHE, HYMALAYA, LUZON, MADAN, MAE SOT, MOROTAI, NORTH AND SOUTH NORFOLK, SOLANDER, SPRATLY, SULU, ALEUTIAN, ALEUTIAN TRENCH, EAST SIBERIA, KHATYRKA, KOMANDARSKY, OR MOCHIGMEN */

expl /* If you do not have a Class IIIBb basin, you should check Klemme's list of Class IIIB basins that he has classified only by the basin's class and did not indicate which of the three basin varieties such as a, b, or $c$ they might be. */yes GENRL no RERUN1

space BIIIB desc $/ *$ Evidence of a Class IIIBb type basin */

inf $/ *$ Congratulations! You have identified a Klemme Class IIIB Rifted Convergent Margin Basin of the Class IIIBb Transform Basin variety. You are ready now to make a detailed analysis of your basin. Good Luck! */

space MEDIAN desc $/ *$ Description of a Klemme Class IIIBc type basin (Median Basin) */

noun-phrase /* IIIBc. Rifted Convergent Margin-Median Basin */

ques $/ *$ DO YOU HAVE ANY ONE OF THE FOLLOWING BASINS, OR A BASIN SIMILAR TO ANY ONE OF THE FOLLOWING ANALOG BASINS, IDENTIFIED BY KLEMME AS A CLASS IIIBc BASIN: BOWSER, CATLOW, HARNEY, HOPE, KOTZEBUE, LAKEVIEW, NORTON, PASCO, QUESNEL, QUINCY, UMATILLA, WHITEHORSE, YAKIMA, ALTIPLANO, CAUCA, CENTRAL CESAR, CUENCA, LOWERMIDDLE-AND UPPER MAGDALENA, MALVINAS, MARACAIBO, NIRIHUAU, OFFSHORE ALGERIAN, ADANA, AEGEAN, ANTALYA, CANKIRI, CRETE, GRAZ, MALATYA, MUS, THRACE, PANNONIAN, SALONIKA, SIVAS, TRANSYLVANIA, TUZ GOLU, VIENNA, DASHT-I-KAVIR, ISFAHAN, GORONTALO, SHANDU SIMAO, SISTAN, AMUR, SOUTH CASPIAN, FERGANA, KURA, AND SUYFUN BASIN */

$\operatorname{expl} / *$ I am trying to determine if your basin is any one of the basins listed in the question, or if your basin is similar to any one of these basins, which are classified by Klemme as a Class IIIBc basin */ yes CIIIB no TRY4

space TRY4 desc /* Description of either a Class IIIBa or IIIBb type basin */

announce $/^{*}$ If you do not have any one of the basins listed in the previous question, you may have a Class

IIIB basin of the type a. (Back Arc Basin), or a type b. (Transform Basin) from the Klemme basin classification. I would suggest that you rerun this Class IIIB model and select one or the other of the basin analog choices. OR you may have already checked these other two options. IF so, then you should check the general list of Class IIIB basins as classified by Klemme without the further distinction of the basins being an a, b, or c variety. */

ques $/ *$ WOULD YOU LIKE TO CHECK THE LIST OF CLASS IIIB BASINS AS CLASSIFIED BY KLEMME, BUT IN WHICH HE DOES NOT DISTINGUISH BETWEEN THE $a, b$, AND c VARIETIES */

expl /* In the AAPG publication of 1984 Klemme has four groups of Class IIIB basins listed among the world basins. They are: 1. IIIBa Back Arc, 2. IIIBb Transform, 3. IIIBc Median, and 4. IIIB Rifted Convergent Margin basins that are not distinguished as to the three varieties listed above as a, b, and c. */yes ZIIIB no RERUN2

space RERUN2 desc /* Evidence of another class of basin */

inf $/^{*}$ It would appear that you do not have a Class IIIBc basin or at least none of the basins listed by Klemme as a IIIBc basin. For whatever reason, you have chosen not to check Klemme's list of basins that he classified only as Class IIIB basins, OR you have checked the list of Class IIIB basins and do not have any of these analog basins. Therefore, I would recommend that you recheck the geologic data on your basin and rerun this model 
space ZIIIB desc $/ *$ Description of a general Class IIIB basin */

ques $/ *$ DO YOU HAVE ONE OF THE FOLLOWING BASINS OR A SIMILAR BASIN THAT KLEMME HAS CLASSIFIED ONLY AS A CLASS IIIB BASIN WITHOUT DISTINGUISHING BETWEEN ANY ONE OF THE THREE VARIETIES a, b, OR c: BETHEL, COPPER RIVER, HOLITNA, MINCHUMINA, ST. MATTHEW, LOWER, MIDDLE, AND UPPER TANANA, YUKON/KANDIK, BURDWOOD BANK, JAMAICA EAST, PUERTO RICO, SOUTH GEORGIA, ALBORAN, DASHT-I-LUT, DJAZ MURIAN, TABRIZ, BEIBU GULF, CAGAYAN, CHANGDU, CHUXIONG, DANJO, HALMAHERA, HEIHE, HYMALAYA, LUZON, MADAN, MAE SOT, MOROTAI, NORTH AND SOUTH NORFOLK, SOLANDER, SPRATLY, SULU, ALEUTIAN, ALEUTIAN TRENCH, EAST SIBERIA, KHATYRKA, KOMANDARSKY, OR MOCHIGMEN */

expl $/^{*}$ If you do not have a Class IIIBc basin, you should check Klemme's list of Class IIIB basins that he has classified only by the basin's class and did not indicate which of the three basin varieties such as a, b, or c they might be. */yes GENRL no RERUN2

space CIIIB desc $/ *$ Description of a Class IIIBc basin */

inf $/^{*}$ Congratulations! You have successfully selected a basin or basin analog from the Klemme IIIBc Rifted Convergent Margin-Median Basin class. You are now ready to make a more detailed analysis of your basin. Good Luck! */ 
APPENDIX J. -INFERENCE NET AND LISTING FOR CLASS IIIC-RIFTED PASSIVE MARGIN BASINS (MODEL 7), FILE NAME RPM

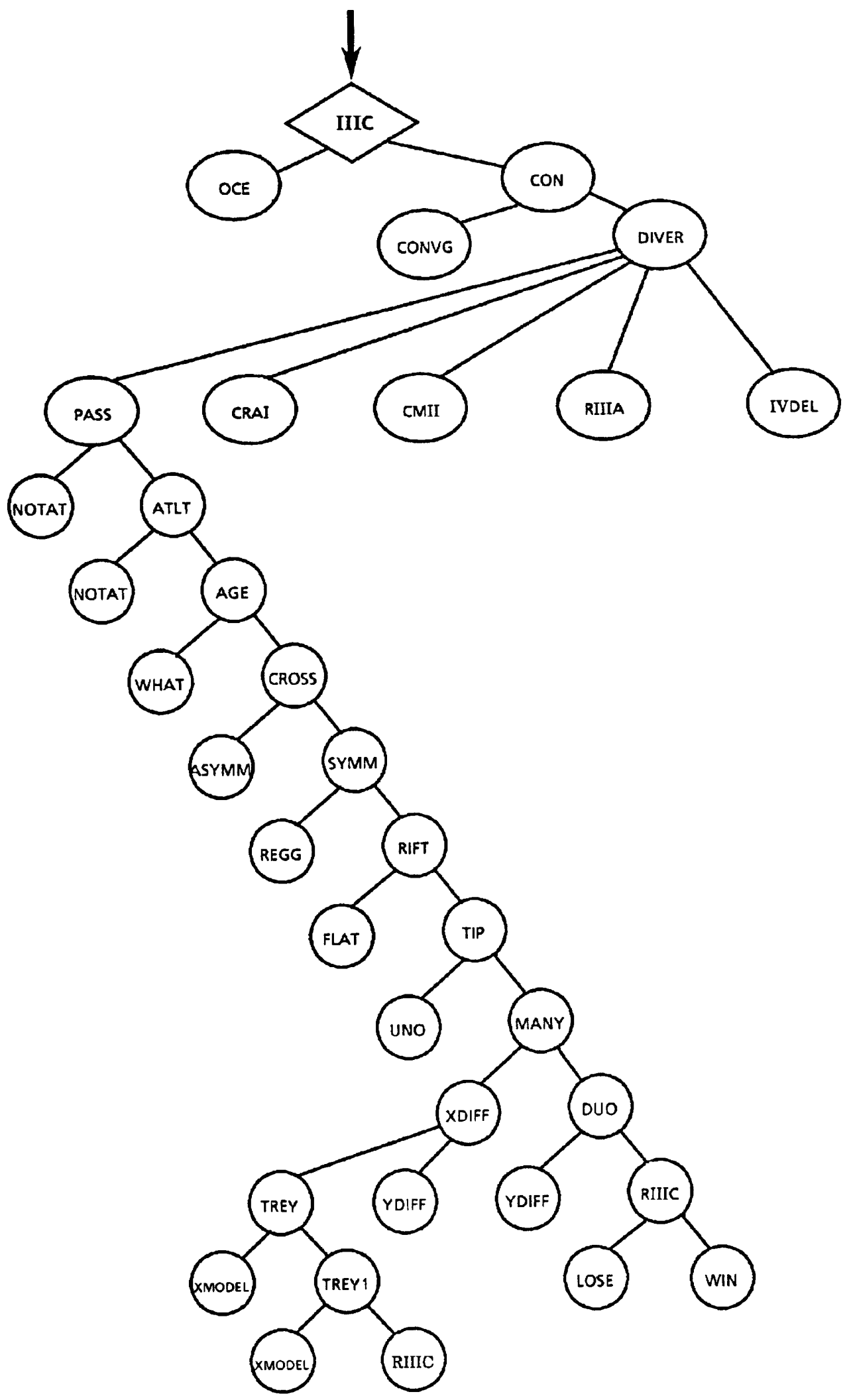

Inference net for Class IIIC-Rifted Passive Margin Basins (model 7), file name RPM.

Appendix J

69 
model RPM

topspace IIIC

space IIIC desc $/^{*}$ Location of prospective basin on continental or partially continental crust rather than oceanic crust */

ques $/ *$ IS YOUR BASIN LOCATED ON CONTINENTAL CRUST OR PRIMARILY CONTINENTAL CRUST (PLATES), AS OPPOSED TO BEING LOCATED PRIMARILY ON OCEANIC CRUST OR OCEANIC PLATES */

expl $/^{*}$ I am trying to determine the location of your basin's position relative to the Earth's major crustal zones, that is, whether the basin is located primarily on continental crust or continental margins that may be partially continental and partially oceanic crust, as opposed to the basin being located completely on oceanic crust */ yes CON no OCE

announce $/ *$ The following is intended to aid in the classification of Continental Rifted Margin Basins */

space OCE desc $/ *$ Evidence of basins located on oceanic crust or primarily on oceanic crust */

inf $/^{*}$ From the description of your basin you may have a forearc basin of the Klemme Class V type (model 9) and you should check that basin model in this world basin classification system. */

space CON desc $/ *$ Evidence of a divergent continental basin */

ques $/ *$ DO YOU HAVE A CONTINENTAL MARGIN BASIN THAT IS LOCATED IN AREAS OF DIVERGENCE OR EXTENSIONAL PULL-APART ZONES AS OPPOSED TO AREAS OF CONVERGENCE OR COLLISIONAL CRUSTAL AREAS */

expl $/ *$ I am trying to determine if your basin is located in a crustal area of primarily divergence with subsidence and separation as opposed to basins located on predominantly convergent crustal areas */ yes DIVER no CONVG

space CONVG desc /* Evidence of convergent basins */

inf $/^{*}$ From the description of your basin it would appear to be one of the following types: either a Class IIC type of the Tethyan variety of basins (model 4), or a Class IIIB type of the Rifted Convergent Margin variety of basins (model 6), or possibly a Class V Forearc Basin variety (model 9). I would recommend that you check these basin models in this world basin classification system. */

space DIVER desc $/ *$ Evidence of continental divergent basins */

announce $/^{*}$ The following is intended to aid in the classification of five different types of divergent continental basins */

choices /* PASS CRAI CMII RIIIA IVDEL */

space CRAI desc $/ *$ Evidence of continental divergent basins */

noun-phrase $/ *$ Craton Interior Divergent Basins-Class I */

inf $/^{*}$ It would appear that you may have a continental basin located in areas of divergence, possibly a continental interior sag or fracture basin. If so, you should check the craton Class I basins (model 1) in this classification. If your basin is located at the margins of an old craton or pericraton, you should check the Continental Multicycle Basins in Klemme Class IIA, IIB, and IIC (models 2, 3, and 4). */

space CMII desc /* Evidence of Class II Continental Multicycle Basins */

noun-phrase /* Continental Multicycle Basins-Class II */

inf $/^{*}$ It would appear that you may have a Klemme Class II basin of the Continental Multicycle type. If so, you may have any one of the following three types of basins: the Class IIA Craton Margin Composite Basins (model 2), the Class IIB Craton-Accreted Margin Complex Basins (model 3), or the Tethyan Class IIC Crustal Collision Zone-Convergent Plate Margin Basins (model 4). You should check these other three basin models in this 
space RIIIA desc $/ *$ Evidence of Class IIIA Continental Rifted Basins */

noun-phrase /* Continental Rifted Basins-Class IIIA Craton and Accreted Zone Rift */

$\inf / *$ It would appear that you may have a Klemme Class III basin of the Continental Rifted type A, Craton and Accreted Zone Rift Basin. These basins are located along present day continental margins as margin sag or rift basins. If so, you should check the Klemme Class IIIA basin (model 5) in this classification system. */

space IVDEL desc /* Evidence of Class IV Delta Basins */

noun-phrase /* Delta Basins-Tertiary to Recent-Class IV */

inf $/^{*}$ It would appear that you may have a Klemme Class IV basin of the Delta Basin type which was probably a continental margin sag basin that has been modified by a delta depocenter of Tertiary to Recent age. If so, please check the Class IV Delta Basin (model 8) in this classification system. */

space PASS desc /* Evidence of a Class IIIC Rifted Passive Margin-Divergent Basin */

noun-phrase /* Rifted Passive Margin Basins of the Atlantic-type-Class IIIC */

ques $/^{*}$ IS YOUR BASIN LOCATED ALONG DIVERGENT CONTINENTAL MARGINS THAT BORDER THE PRESENT DAY ATLANTIC OCEAN, OR THE INDIAN OCEAN, OR THE ARCTIC OR ANTARCTIC OCEANS AS OPPOSED TO THE CIRCUM-PACIFIC OR THE TETHYAN SEAWAYS */

expl /*I am trying to determine whether your divergent continental margin basin is located either along the borders of the Atlantic, Indian, or Arctic or Antarctic oceans, as opposed to a location around the circum-Pacific borders or in the Tethyan seaways (including the Gulf of Mexico). */yes ATLT no NOTAT

space NOTAT desc /* Evidence of non-Atlantic-type basins */

inf $/^{*}$ If your basin is not located along the Atlantic-Indian-Arctic-Antarctic continental margins, and if it is located either in the circum-Pacific continental borders or in the Tethyan seaways, then you probably have a convergent-type continental margin basin and you should check either the Klemme Class IIC or IIIB basins (models 4 and 6). If you do have a continental divergent margin basin but in a different location than those already noted, you should check the Klemme Class IIB or IIIA (models 3 and 5) in this classification system. */

space ATLT desc $/ *$ Evidence of passive margin basins */

ques $/ *$ IS YOUR BASIN LOCATED ALONG THE CONTINENTAL MARGINS ON CRATON OR ACCRETED ZONES IN CONTINENTAL MARGIN COASTAL ZONES, AND THE BASIN AXIS LIES PARALLEL WITH THE CONTINENTAL-OCEANIC CRUST BOUNDARY, AND THE SEDIMENTS MAY OVERLAP ONTO OCEANIC CRUST */

expl $/^{*}$ I am trying to determine if you have the classical description of a passive margin Atlantic-type basin, where divergence within the plate occurred by parallel or transform separation of the continental crust from oceanic crust. Sediments may overlap from the continental onto the oceanic crust */ yes AGE no NOTAT

space AGE desc $/ *$ Evidence of a post-Paleozoic basin */

ques $/ *$ IS YOUR BASIN LOCATED ALONG A CONTINENTAL MARGIN SUCH THAT IT EXTENDS FROM A COASTAL PLAIN TO AN OCEAN DEEP AND WAS FORMED IN THE POST-PALEOZOIC (TRIASSIC OR YOUNGER). */

expl /* I am trying to determine if your basin, located on a craton margin or the accreted zones of continental margin coastal areas, extends offshore and may overlie oceanic crust, and was formed in post-Paleozoic times */yes CROSS no WHAT

space WHAT desc $/ *$ Evidence of a different basin model */

inf $/ *$ From the description of your basin and particularly the location and age of basin formation, you may be missing important information on your basin and may wish to check some of the other Craton-Accreted Margin 
Complex Basin models, particularly Class IIB, IIIA, and IIIB (models 3, 5 and 6) in this classification. */

space CROSS desc $/ *$ Evidence of a symmetrical basin */

ques ${ }^{*}$ DO YOU HAVE A BASIN WHOSE PROFILE OR CROSS SECTION ACROSS THE BASIN AT CONTACT OF SEDIMENTS WITH BASEMENT IS ESSENTIALLY SYMMETRICAL AS OPPOSED TO BEING ASYMMETRICAL */

expl $/^{*}$ I am trying to determine if you have a symmetrically shaped basin as opposed to an asymmetrically shaped basin */ yes SYMM no ASYMM

space ASYMM desc /* Evidence of asymmetrical basin models */

inf $/^{*}$ From the description of your basin it would appear that you have an asymmetrically shaped basin and you should check the other Klemme Class II basins (models 2, 3, and 4) in this classification, or possibly Class IV basins (model 8). $\%$

space SYMM desc $/ *$ Evidence of a symmetrical, irregular basin $* /$

ques $/ *$ DOES YOUR BASIN HAVE AN IRREGULAR PROFILE DUE TO EITHER A SINGLE OR MULTIPLE RIFTED BASEMENT WITH RIFT DIVERGENCE (PARALLEL OR TRANSFORM) DUE TO SEA-FLOOR SPREADING, WHICH MAY BE FOLLOWED BY A LINEAR HALF-SAG ORIENTED DOWNDIP AND SEAWARD */

expl /*I am trying to determine if your symmetrical basin has an irregular basement profile due to rifting, and if it lies on a continental margin where rift divergence was caused due to sea-floor spreading in its early history (possibly in the Jurassic). The sea-floor spreading may or may not have been followed by a linear half-sag oriented downdip and seaward. */yes RIFT no REGG

space REGG desc /* Evidence of a symmetrical, regular basin */

inf $/^{*}$ From the description of your basin you have a symmetrically shaped basin with a regular basement profile that has not been modified due to any basement rifting or block faulting. You may have some modified form of a Klemme Class I basin (model 1) or a Class IV basin (model 8). You should check these other basin models. */

space RIFT desc /* Evidence of a symmetrical, irregular, tilted basin */ ques ${ }^{*}$ DO YOU HAVE A SYMMETRICAL, IRREGULAR SHAPED BASIN THAT IS TILTED SEAWARD *I

expl /* I am trying to determine if your basin has been tilted seaward as opposed to being essentially level or horizontal in position */ yes TIP no FLAT

space FLAT desc /* Evidence of a horizontal, irregular, symmetrical basin */

inf $/ *$ From the description of your basin you may have a craton margin sag basin that is better described by Klemme Class II basins, or a IIIA or IIIB basin. You should check basin models 2, 3 and 4, or models 5 and 6 in this basin classification system. $* /$

space TIP desc $/ *$ Evidence of a multicycle basin */

ques $/ *$ DOES YOUR BASIN HAVE AT LEAST TWO MAJOR MORPHOLOGIC CYCLES OR SEQUENCES AS OPPOSED TO BEING ONLY A SINGLE CYCLE BASIN */

expl /* I am trying to determine if you have at least two major morphologic cycles or sequences (two or more), rather than a single cycle basin */ yes MANY no UNO

space UNO desc $/ *$ Evidence of a single cycle basin */

inf $/ *$ From the description of your basin you may have a modified Class I or IIB basin model, or a Class IV

Delta Basin, or a very remote possibility of a Class V basin. You should check out basin models 1, 3, 8, or 9. It is also quite possible that you have more than a single cycle basin and are missing important tectonic or depositional information for your basin. In that case I would recommend that you rerun this same model (IIIC) and assume 
more than a single cycle basin. ${ }^{*} /$

space MANY desc $/ *$ Evidence of a two-cycle Atlantic-type basin */

ques ${ }^{*}$ DO YOU HAVE A TWO-CYCLE BASIN WITH EXACTLY THE FOLLOWING TWO-CYCLE SEQUENCE: THE FIRST CYCLE OF A BASIN LOCATED ALONG DIVERGENT MARGINS WHERE TENSION DEVELOPS PARALLEL AND TRANSFORM, TILTED RIFTS AND RIFT-FILL, FOLLOWED BY A SEAWARD DIRECTED SECOND CYCLE OF A LINEAR HALF-SAG SEQUENCE, AS OPPOSED TO A BASIN WITH MORE THAN TWO CYCLES */

expl $/^{*}$ I am trying to determine if you have a two-cycle basin (as opposed to more than two cycles) and if you have the two major morphologic cycles as exactly described in the question. If you have more than a two-cycle basin, or if your two-cycle basin would be described as having a different sequence of cycles than given in the question, then answer NO. */yes DUO no XDIFF

space DUO desc $/ *$ Evidence of one type of Class IIIC basin */

ques $/ *$ DO YOU THINK YOU HAVE A RIFTED PASSIVE MARGIN BASIN LOCATED IN AN AREA OF DIVERGENCE, WITH A PARALLEL RIFT SYSTEM OR A TRANSFORM FAULTED SYSTEM, THAT MAY BE A KLEMME CLASS IIIC BASIN */

expl /* I am trying to determine if you have a Rifted Passive Margin Basin of the Parallel subclass or the Transform faulted subclass of the Klemme Class IIIC */ yes RIIIC no YDIFF

space XDIFF desc $/ *$ Evidence of a different type of two-cycle basin */

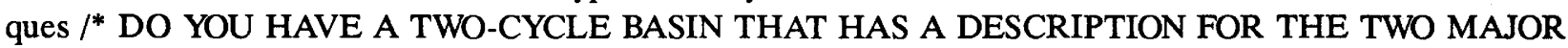
MORPHOLOGIC CYCLES THAT IS QUITE DIFFERENT FROM THAT OF A MARGINAL RIFT AND RIFT-FILL CYCLE, FOLLOWED BY A LINEAR HALF-SAG CYCLE, AS OPPOSED TO A BASIN WITH THREE OR MORE MAJOR MORPHOLOGIC CYCLES */

expl $/^{*}$ I am trying to determine if you have a two-cycle basin whose two cycles are different than the sequence as expressed in the question, as opposed to having a basin with three or more morphologic cycles. If you have a different two-cycle basin, answer Yes. If you have a three or more cycle basin, answer No */ yes YDIFF no TREY

space YDIFF desc $/ *$ Evidence of other two-cycle basins */

inf $/^{*}$ From the description of your basin it would appear that the two-cycle sequence in your basin would indicate it is either of the Class II varieties (models 2, 3, and 4), or of the Class IIIA or IIIB variety (models 5 and 6). I would recommend that you check these other basin models. */

space TREY desc $/ *$ Evidence of a three-cycle Class IIIC basin */

ques $/ *$ DO YOU HAVE A BASIN WITH THREE MAJOR MORPHOLOGIC CYCLES IN THE FOLLOWING EXACT SEQUENCE: THE FIRST CYCLE IS A PLATFORM WEDGE (OFTEN PARTIALLY ERODED) ONLAPPING THE CRATON, FOLLOWED BY A SECOND CYCLE WHERE TENSION DEVELOPS PARALLEL AND TRANSFORM TILTED RIFTS AND RIFT-FILL WHICH OFTEN INCLUDES A DOWNDROPPED FIRST CYCLE CRATON ONLAP, AND WITH THE RIFTS OVERLAIN BY A THIRD CYCLE LINEAR HALF-SAG SEQUENCE DIRECTED SEAWARD, AS OPPOSED TO A BASIN WITH A DIFFERENT THREE OR MORE CYCLE SEQUENCE */

$\operatorname{expl} /^{*}$ I am trying to determine if you have a three-cycle basin, and if you have the exact three-cycle sequence as given in the question. If so, answer YES. If you have a three-cycle basin of a different sequence or more than three cycles in your basin, then answer NO. */ yes TREY1 no XMODEL

space TREY1 desc /* Evidence of a Class IIIC Rifted Passive Margin Basin */

ques $l^{*}$ DO YOU THINK YOU HAVE A PASSIVE MARGIN BASIN LOCATED IN AN AREA OF DIVERGENCE WITH A PARALLEL RIFT SYSTEM OR A TRANSFORM FAULT SYSTEM OF THE KLEMME CLASS IIIC TYPE */

expl /* I am trying to determine if you think your Rifted Passive Margin Basin is of the Klemme Class IIIC 
space XMODEL desc /* Evidence of other three or more cycle basins */

inf $/^{*}$ From the description of your basin you either have a three-cycle basin that is different than the threecycle Rifted Passive Margin Basin, or you may have more than a three-cycle basin. In either case you may have one of the three types of Klemme Class II basins (models 2, 3 and 4). Check these other basin models. */

space RIIIC desc $/ *$ Evidence of Klemme Class IIIC analog basins */

announce $/^{*}$ Congratulations! From the description of your basin you have either a two-cycle or a three-cycle Rifted Passive Margin Basin of the Klemme Class IIIC type. The following questions will aid in determining if you have one of the basins classified by Klemme as Class IIIC analog basins. */

ques $/ *$ IS YOUR BASIN ONE OF THE FOLLOWING KLEMME CLASS IIIC ANALOG BASINS: ANGMAGSSALIK, ARCTIC SHELF, EAST AND WEST BAFFIN, BALTIMORE CANYON, BLAKE PLATEAU AND OUTER RIDGE, SE CAMPECHE, CUMBERLAND, DAVIS STRAIT, FLORIDA-BAHAMA, GEORGES BANKS, GRAND BANKS, EAST AND CENTRAL GREENLAND, KRONPRINS CHRISTIAN, LABRADOR, MCKINLEY, NUWUK, SCOTIA SHELF, VERACRUZ (IIICc), AMATIQUE, MOUTH OF THE AMAZON, BAHIA SUL, BARREIRINHAS, CAMPOS, CEARA, COLORADO-ARGENTINA, ESPIRITO SANTO, FALKLAND, GUIANA, NORTH COAST HONDURAS, JAMAICA WEST, NICARAGUA RISE, PARA-MARANHAO, PELOTAS, POTIGUAR, SALADO, SANTOS, AAIUN, ALGOA, BERBERA, CABINDA, SERGIPE-ALAGOAS, CAMEROON, CORIOLE, CUANZA, ESSAOUIRA, GABON, GAMTOOS, GHANA, HAFUN, IVORY COAST, LIBERIAN, LIMPOPO, MAJUNGA, MOCAMEDES, MORONDAVA, MUDUGH, ORANGE RIVER, WEST RED SEA, SENEGAL, WEST SEYCHELLES, SOUTH AFRICAN, TANZANIA, TARFAYA, WALVIS, BAY OF BISCAY, HARSTAD, HATTON, HELGELAND, MORE, LUSITANIA, ROCKALL, WEST SHETLANDS, MASIRA, MUKALLA, EAST RED SEA, ANDAMAN SEA, BEAGLE, BOMBAY, BONAPARTE GULF, BROWSE, CANNING OFFSHORE, CARNARVON OFFSHORE, CAUVERY, CHALLENGER, DAMPIER, DUNTROON, EUCLA, HALIFAX (AUSTRALIA), KERALA, KRISHNA, KUTCH, LORD HOWE, MAHANADI, MAKRAN (IIICb), GULF OF MARTABAN, MARYBOROUGH, MEKONG (IIICc-IV), NATURALISTE, OTWAY, PALAR, NORTH PALAWAN, PEARL RIVER FAN, QUEENSLAND, RECHERCHE, SAURASHTRA, TARANAKI, TASMAN, EAST AND WEST TASMANIA, VIETNAM, YINGGEHAI, WEDDELL (IIB-IIIC) */

expl /* I am trying to determine if you might have one of the analog basins that Klemme has classified as a Class IIIC basin, or a basin similar in geology to one of his analog basins. */ yes WIN no LOSE

space WIN desc $/ *$ Evidence of a successful classification of a Klemme-type Class IIIC basin */

inf /* Congratulations! You have successfully described a Klemme Class IIIC basin and you have matched one of the Klemme analog basins or you have a basin with geology similar to one of the Klemme basin analogs. You are now ready to make a detailed analysis of your basin. */

space LOSE desc $/ *$ Insufficient information for a basin analog match */

inf $/ *$ According to all the information you have given on your basin it would appear that you have a Klemme Class IIIC basin. However, you did not pick an analog basin from Klemme's basin list or consider that your basin might be similar to any one of these analog basins. You may have insufficient data to match your basin with an analog basin, or you may need to rerun this model and reevaluate some of your answers to the questions. Finally, you may wish to check some of the other basin models with similar geologic attributes that are in this world basin classification system. Good Luck! */

STOP 


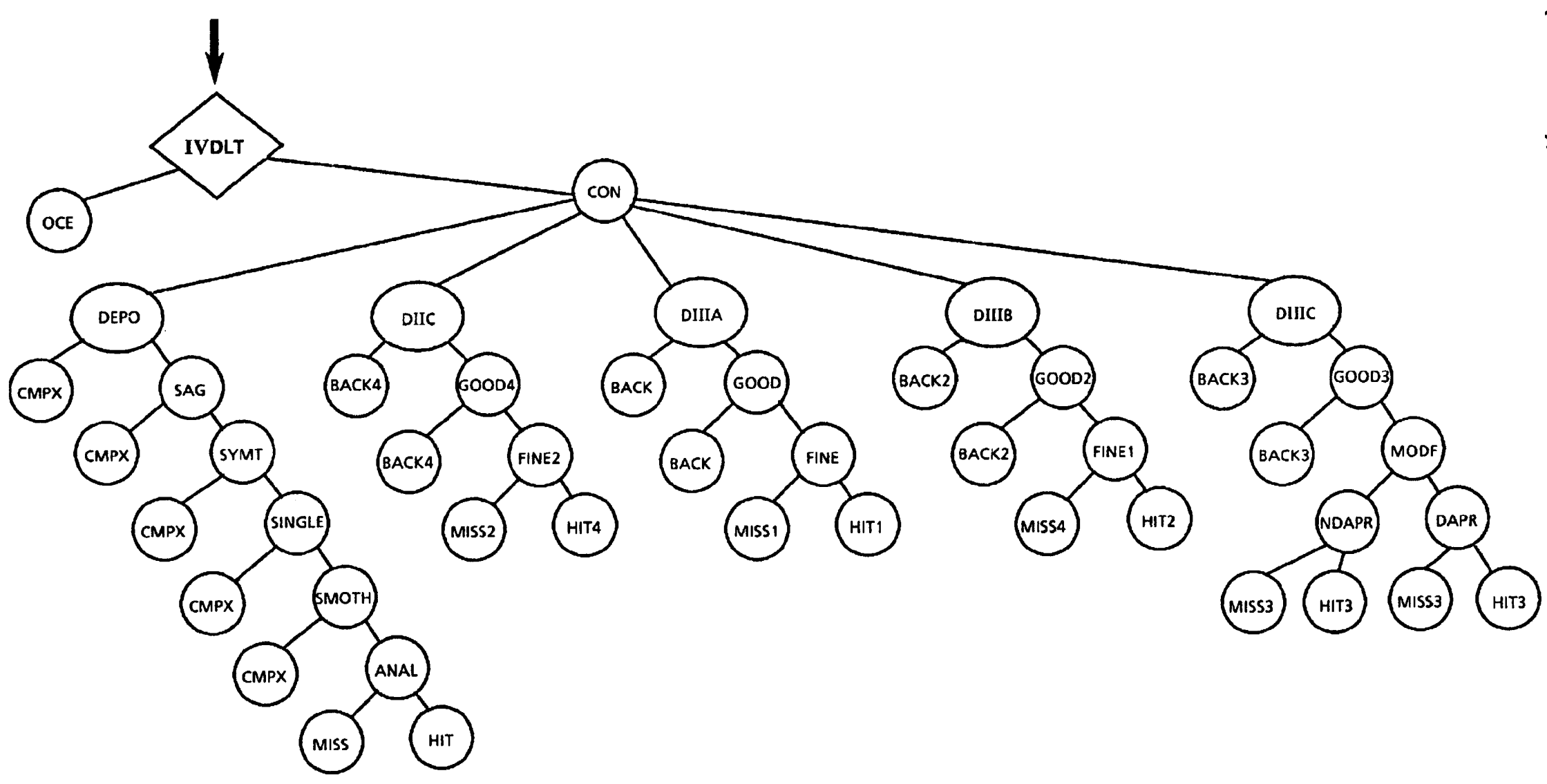

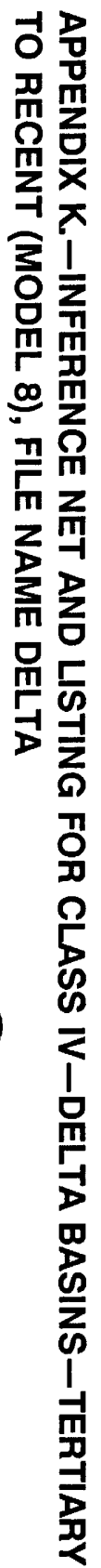

ขै Inference net for Class IV-Delta Basins-Tertiary to Recent (model 8), file name DELTA. 
model DELTA

topspace IVDLT

space IVDLT desc $/ *$ Location of Delta Basins-Tertiary to Recent on continental or partially continental crust rather than oceanic crust *I

ques ${ }^{*}$ IS YOUR BASIN LOCATED ON CONTINENTAL CRUST OR PRIMARILY CONTINENTAL CRUST (PLATES), AS OPPOSED TO BEING LOCATED PRIMARILY ON OCEANIC CRUST OR OCEANIC PLATES *I

expl /* I am trying to determine the location of your basin relative to the Earth's major crustal zones. That is, whether the basin is located primarily on continental crust or continental margins, or on partially continental and partially oceanic crust, as opposed to the basin being located completely on oceanic crust. */ yes CON no OCE

space OCE desc $/ *$ Evidence of basins located primarily on oceanic crust */

inf $/^{*}$ From the description of your basin you may have a forearc basin of the Klemme Class $\mathrm{V}$ type and you should check basin model 9 in this world basin classification system. */

space CON desc /* Evidence of Delta Basins in all basin classes */

announce $/^{*}$ Delta Basins may occur in several different geologic basin settings. They may be of a simplified form with a simple Tertiary delta depocenter, or they may be a last-cycle modification of very complex basin forms. These complex basins are usually of the Klemme Class II or Class III varieties that have been modified further by the delta depocenter. The following is intended to aid in the classification of a variety of Delta Basins. */ choices /* DEPO DIIC DIIIA DIIIB DIIIC */

space DEPO desc $/ *$ Evidence of a simplified Delta Depocenter Basin */

noun-phrase /* IV. Delta Depocenter Basin-Simplified */

ques $/ *$ IS YOUR BASIN LOCATED ALONG A CONTINENTAL MARGIN OR CONTINENTALOCEANIC MARGIN AS A SIMPLE EXTENSIONAL OR MODIFIED SAG, PROBABLY TERTIARY IN AGE, AS OPPOSED TO A COMPLEX BASIN WITH A DELTA DEPOCENTER */

expl /* I am trying to determine if you have a deltaic basin of the simplest variety that consists essentially of an extensional sag located as a continental margin basin, as opposed to a complex basin modified by a delta depocenter. */yes SAG no CMPX

space CMPX desc /* Description of complex basins modified by delta depocenters */

inf $/^{*}$ From the description of your basin it would appear that you may have either a Klemme Class II or Class III basin that has been modified recently by a delta depocenter. I would recommend that you rerun this basin model and make another selection from the modified or more complex delta basin model. Select one of the options 2 through $5 . * 1$

space SAG desc $/ *$ Evidence of a symmetrical delta depocenter basin */

ques $/^{*}$ DO YOU HAVE A SYMMETRICAL BASIN TILTED SEAWARD WITH A PRE-SAG CYCLE THAT LIES ESSENTIALLY BELOW 35,000 FEET AND WITH A DELTA DEPOCENTER OF TERTIARY AGE */

expl /* I am trying to determine if you have a delta depocenter of Tertiary age that lies in a simple symmetrical extensional sag along a continental margin, as opposed to a more complex basin, possibly asymmetrical and irregular in shape, and tilted seaward with a delta depocenter. The pre-sag cycle may lie as much as 35,000 feet below sea level. */yes SYMT no CMPX

space SYMT desc /* Evidence of a regular, symmetrical delta basin */

ques $/ *$ DOES YOUR BASIN HAVE ESSENTIALLY AN UNALTERED REGULAR BASEMENT PRO-

FILE UNAFFECTED BY ANY BLOCK OR RIFT FAULTING, AS OPPOSED TO AN IRREGULAR BASEMENT PROFILE ALTERED BY FAULTING */ 
expl $/^{*}$ I am trying to determine whether you have a simple delta depocenter basin of Tertiary age with a regular basement profile that has essentially been unaffected by block faulting or rifting. */ yes SINGLE no CMPX

space SINGLE desc $/ *$ Evidence of a single-cycle symmetrical delta depocenter basin */

ques $/ *$ DO YOU HAVE A BASIN THAT HAS ESSENTIALLY ONE MAJOR MORPHOLOGIC CYCLE OR SEQUENCE WITH A DELTA DEPOCENTER LOCATED IN A PRE-SAG CYCLE THAT MAY LIE BELOW 35,000 FEET AS OPPOSED TO A MULTICYCLE BASIN */

expl $/^{*}$ I am trying to determine if your delta basin is a single-cycle basin as opposed to a multicycle basin. */yes SMOTH no CMPX

space SMOTH desc /* Evidence of a simplified Delta Basin of the Klemme Class IV */

announce $/ *$ Congratulations! It would appear that you have a simplified Klemme Class IV Delta Basin. */

ques $/ *$ DO YOU THINK YOU HAVE A SIMPLIFIED DELTA BASIN OF THE KLEMME CLASS IV BASIN TYPE, AS OPPOSED TO A MORE COMPLEX DELTAIC BASIN */

expl $/^{*}$ I am trying to determine if you think you have such a simple delta basin or if you may have a much more complex geologic basin that has been modified recently by a delta depocenter of Tertiary age. */ yes ANAL no CMPX

space ANAL desc $/ *$ Evidence of one of the simple delta analog basins */

ques ${ }^{*}$ DO YOU HAVE ONE OF THE FOLLOWING KLEMME CLASS IV DELTA BASINS, OR A BASIN THAT MIGHT BE A GEOLOGIC ANALOG TO THESE TERTIARY BASINS: MACKENZIE DELTA, MAGDALENA DELTA AND FAN, ORINOCO DELTA, NIGER DELTA, NILE DELTA AND NILE FAN, INDUS DELTA AND INDUS FAN, AND IRRAWADDY DELTA */

expl /* I am trying to determine if you really have a very simple form of a Tertiary Delta Basin or if you may have a Delta Basin of a more complex geologic form */ yes HIT no MISS

space HIT desc $/ *$ Evidence of a Class IV Simplified Delta Basin */

inf $l^{*}$ Congratulations! From the description of your basin it would appear that you have a simplified single-cycle delta depocenter basin of the Klemme Class IV type. You are now ready to make a more detailed analysis of your basin. If you are uncertain, however, whether your basin may have had a more complex geologic history, I would highly recommend that you rerun this model and check the other delta depocenter basin options within this same Class IV. */

space MISS desc /* Evidence of a complex Delta Basin */

inf $/^{*}$ If you were uncertain whether your delta depocenter basin might be one of a more complex geologic history, that is fine! Many of the delta basins given in a basin analog list may be classified first as one of the other eight classes of Klemme basins and then modified as a Delta Basin of the Class IV type. I would recommend that you rerun this Class IV basin model and select a different option to check for a more complex delta depocenter basin classification. Good Luck! */

space DIIIA desc $/ *$ Evidence of a Class IIIA continental rifted basin modified by a Delta depocenter */ noun-phrase /* IV-IIIA Continental Rifted Basin modified by a Delta Basin */

ques $/ *$ HAVE YOU ALREADY RUN THE CLASS IIIA CONTINENTAL RIFTED BASIN MODEL (MODEL 5) IN THIS CLASSIFICATION SYSTEM SO THAT YOU ARE FAIRLY CERTAIN THAT YOU HAVE A CLASS IIIA BASIN */

expl /* I am trying to determine if you have already classified your complex basin as to it being in the Class IIIA category prior to modification by a delta depocenter of Tertiary age */ yes GOOD no BACK

space BACK desc /* Recommendation for checking basin model IIIA first */ inf $/^{*}$ If you are uncertain whether your complex basin is of the Class IIIA type (Craton and Accreted Zone Rift Basin), you should go back and first run Class IIIA basin (model 5) for the basin description. Then, if your 
Class IIIA basin has been modified further by a delta depocenter of Tertiary age, return to this Class IV basin (model 8) for final description of your basin. $*$ /

space GOOD desc /* Evidence of a Class IIIA-IV basin */

ques $/^{*}$ DO YOU HAVE A MULTICYCLE, NON-TETHYAN BASIN THAT IS LOCATED INTERIOR FROM THE CONTINENTAL MARGINS AND WHERE THE FIRST CYCLE IS USUALLY A WELL DEVELOPED SINGLE RIFT, OR A UNIDIRECTIONAL AND PARALLEL SET OF CLOSELY SPACED RIFTS AND GRABENS, OVERLAIN BY A LINEAR SAG PARALLEL TO THE UNDERLYING RIFTS AND MODIFIED BY THE OCCURRENCE OF A DELTA DEPOCENTER OF TERTIARY AGE WITHIN THE BASIN *I

expl /* I am summarizing the basic description of a Class IIIA Klemme basin that is further modified by a delta depocenter of Tertiary age. If you are uncertain as to whether your complex basin is of the Class IIIA type, then answer NO. */yes FINE no BACK

space FINE desc $/ *$ Evidence of a IIIA-IV basin analog */ ques ${ }^{*}$ IS YOUR BASIN THE RHONE DELTA BASIN IN FRANCE, WHICH HAS BEEN CLASSIFIED BY KLEMME AS A CLASS IIIA-IV BASIN, OR A BASIN VERY SIMILAR GEOLOGICALLY TO THIS ANALOG BASIN */

expl /*I am trying to determine if the basin you have described is the Rhone Delta Basin, which Klemme classifies as a Class IIIA modified by a Class IV basin (or a similar basin).*/yes HIT1 no MISS1

space HIT1 desc /* Evidence of a Class IIIA basin modified by a Class IV basin */

inf $/^{*}$ Congratulations! From the description of your basin it would appear that you have a complex basin modified by a Tertiary delta depocenter which is classified as a Klemme Class IIIA Craton and Accreted Zone Rift Basin modified by a Class IV Delta Basin. You are now ready to make a more detailed analysis of your basin. */

space MISS1 desc /* Evidence of other complex basins modified by a Tertiary delta depocenter */

inf $/^{*}$ If you are uncertain whether your complex basin is of the class described in the previous question followed by a delta depocenter, I would recommend that you rerun this Class IV basin model and select a different option for a complex basin modified by a delta depocenter, such as the IIC-IV or IIIB-IV or the IIIC-IV options. Good Luck! */

space MISS2 desc /* Evidence of other complex basins modified by a Tertiary delta depocenter */

inf $l^{*}$ If you are uncertain whether your complex basin is of the class described in the previous question followed by a delta depocenter, I would recommend that you rerun this Class IV basin model and select a different option for a complex basin modified by a delta depocenter, such as the IIIA-IV or IIIB-IV or the IIIC-IV options. Good Luck! */

space MISS3 desc /* Evidence of other complex basins modified by a Tertiary delta depocenter */

inf $l^{*}$ If you are uncertain whether your complex basin is of the class described in the previous question followed by a delta depocenter, I would recommend that you rerun this Class IV basin model and select a different option for a complex basin modified by a delta depocenter, such as the IIC-IV or IIIA-IV or the IIIB-IV options. Good Luck! */

space MISS4 desc $/ *$ Evidence of other complex basins modified by a Tertiary delta depocenter */

inf $l^{*}$ If you are uncertain whether your complex basin is of the class described in the previous question followed by a delta depocenter, I would recommend that you rerun this Class IV basin model and select a different option for a complex basin modified by a delta depocenter, such as the IIC-IV or IIIA-IV or the IIIC-IV options. Good Luck! */ 
space DIIIB desc $/^{*}$ Evidence of a Class IIIB Rifted Convergent Margin Basin modified by a IV Delta depocenter basin $* /$

noun-phrase /* IV-IIIB Continental Rifted Convergent Margin Basin modified by a Delta Basin */

ques $/ *$ HAVE YOU ALREADY RUN THE IIIB RIFTED CONVERGENT MARGIN BASIN MODEL (MODEL 6) IN THIS CLASSIFICATION SYSTEM SO THAT YOU ARE FAIRLY CERTAIN THAT YOU HAVE A CLASS IIIB BASIN */

expl $/^{*}$ I am trying to determine if you have already classified your complex basin as to being in the Class IIIB category prior to its modification by a delta depocenter of Tertiary age */ yes GOOD2 no BACK2

space BACK2 desc /* Recommendation for running model for Class IIIB basin */

inf $l^{*}$ If you are uncertain whether your complex basin is of the Class IIIB type (Rifted Convergent Margin-Oceanic Consumption Basin), you should go back and first run basin model 6 for the Class IIIB Klemme basin description. Then, if your Class IIIB basin has been modified further by a delta depocenter of Tertiary age, return to this basin Class IV model for final description of your basin. */

space GOOD2 desc $/ *$ Evidence of a Class IIIB-IV basin */

ques $/ *$ DO YOU HAVE A MULTICYCLE BASIN THAT IS LOCATED EITHER BORDERING THE CIRCUM-PACIFIC OR LIES IN THE CENTRAL TETHYS WHERE CONVERGENT OR TRANSFORM PLATE MOTION DUE TO SUBDUCTION OCCURS, AND WHERE UNIDIRECTIONAL RIFTED, ACCRETED BASEMENT IS OVERLAIN BY A LINEAR SAG PARALLEL TO RIFTING, AND ALL MODIFIED BY THE OCCURRENCE OF A TERTIARY DELTA DEPOCENTER WITHIN THE BASIN */

expl /* I am summarizing the basic description of a Klemme Class IIIB basin, which may be either a back arc, a transform, or a median basin, that is further modified by a delta depocenter of Tertiary age. If you are uncertain as to whether your complex basin is of the Class IIIB type, then answer No. */yes FINE1 no BACK2

space FINE1 desc $/ *$ Evidence of a Class IIIB-IV basin analog */

ques $/ *$ IS YOUR BASIN ONE OF THE FOLLOWING CLASS IIIB-IV BASINS AS CLASSIFIED BY KLEMME: THE MAHAKAM DELTA IN INDONESIA (IIIBa-IV), THE BEIBU GULF DELTA BETWEEN CHINA AND VIETNAM, OR A BASIN VERY SIMILAR GEOLOGICALLY TO THESE ANALOG BASINS */

expl /* I am trying to determine if the basin you have described is either of the basins described in the question which Klemme classified as a Class IIIB basin modified by a Class IV basin (or a similar basin) */ yes HIT2 no MISS4

space HIT2 desc $/^{*}$ Evidence of a Class IIIB basin modified by a Class IV basin */

inf $/^{*}$ Congratulations! From the description of your basin you appear to have a Class IIIB basin of the Rifted Convergent Margin variety that may occur in either the borders of the circum-Pacific or in the Central Tethys (oceanic-continental subduction zones) and modified by a Tertiary delta depocenter basin of the Klemme Class IV type. You are now ready to make a more detailed analysis of your basin. Good Luck! */

space DIIIC desc $/^{*}$ Evidence of a Class IIIC Continental Rifted Passive Margin basin modified by a Delta depocenter */

noun-phrase /* IV-IIIC Continental Rifted Passive Margin Basin modified by a Delta Basin */

ques /* HAVE YOU ALREADY RUN THE IIIC CONTINENTAL RIFTED PASSIVE MARGIN BASIN MODEL IN THIS CLASSIFICATION SYSTEM SO THAT YOU ARE FAIRLY CERTAIN THAT YOU HAVE A CLASS IIIC BASIN */

expl $/ *$ I am trying to determine if you have already classified your complex basin as to being in the Class IIIC category prior to modification by a delta depocenter of Tertiary age */ yes GOOD3 no BACK3

space BACK3 desc /* Recommendation for running Class IIIC basin model */

inf $/^{*}$ If you are uncertain whether your complex basin is of the Class IIIC type (Continental Rifted Passive Margin Basin), you should go back and first run basin model 7 for the Class IIIC Klemme basin description. Then, 
if your Class IIIC basin has been modified further by a delta depocenter of Tertiary age, return to this basin Class IV (model 8), for final description of your basin. */

space GOOD3 desc /* Evidence of a Class IIIC-IV basin */

ques $/ *$ DO YOU HAVE A MULTICYCLE NON-TETHYAN BASIN THAT IS LOCATED ALONG THE BORDERS OF THE ATLANTIC, INDIAN, ARCTIC, OR ANTARCTIC OCEANS, AND THAT MAY EXTEND OFFSHORE OVER OCEANIC CRUST, ALONG DIVERGENT MARGINS WHERE TENSION DEVELOPS SECOND CYCLE PARALLEL AND TRANSFORM TILTED RIFTS AND RIFT BLOCKS (WHICH OFTEN INCLUDE DOWNDROPPED FIRST CYCLE CRATON ONLAP), AND THE RIFTS ARE OVERLAIN BY A THIRD CYCLE OF A LINEAR HALF-SAG DIRECTED SEAWARD, AND ALL BEING MODIFIED BY THE OCCURRENCE OF A DELTA DEPOCENTER OF TERTIARY AGE WITHIN THE BASIN */

expl /* This question is a mouthful. But I am just summarizing the basic description of a Class IIIC Klemme basin that is further modified by a delta depocenter of Tertiary age. If you are uncertain as to whether your complex basin is of the Class IIIC type, then answer NO */ yes MODF no BACK3

space MODF desc $/ *$ Evidence of a modified Class IIIC-IV basin */

announce $/^{*}$ Congratulations! From the description of your basin it appears that you have a Class IIIC (Continental Rifted Passive Margin Basin) modified by a Class IV Delta Basin. The following questions will aid you in further defining your Class IIIC-IV basin. *I

ques /* IS YOUR CLASS IIIC-IV BASIN FURTHER MODIFIED BY GRAVITY TECTONIC FEATURES THAT ALSO INCLUDE EITHER SHALE DIAPIRS AND (OR) SALT DIAPIRS */

expl $/ *$ I am trying to determine if your basin has been modified in addition to the delta depocenter, by salt and (or) shale diapirs */ yes DAPR no NDAPR

space DAPR desc $/ *$ Evidence of diapiric Class IIIC-IV basin analogs */

ques /* IS YOUR BASIN THE NIGER DELTA OFF WEST AFRICA OR A BASIN VERY SIMILAR GEOLOGICALLY TO THIS ANALOG BASIN */

expl /* I am trying to determine if the basin you have described is the Niger Delta Basin, which Klemme classifies as a Class IIIC modified by a Class IV basin (or a similar basin). */yes HIT3 no MISS3

space HIT3 desc $/ *$ Evidence of a Class IIIC basin modified by Class IV basin */

inf $/^{*}$ Congratulations! From the description of your basin it would appear that you have described a Klemme Class IIIC (Continental Rifted Passive Margin Basin) modified by a Tertiary delta depocenter of the Class IV Delta Basin type. You are now ready to make a more detailed analysis of your basin. */

space NDAPR desc $/ *$ Evidence of a nondiapiric Class IIIC-IV Basin */

ques $/ *$ DO YOU HAVE ONE OF THE FOLLOWING BASINS OR A BASIN VERY SIMILAR GEOLOGICALLY TO THESE ANALOG BASINS THAT HAVE BEEN CLASSIFIED BY KLEMME AS A CLASS IIIC-IV BASIN: THE MOUTH OF THE AMAZON IN BRAZIL, THE ORANGE RIVER DELTA IN NAMIBIA, SOUTH AFRICA, OR THE MEKONG DELTA IN VIETNAM (IIICc-IV) */

expl /* I am trying to determine if the basin you have described is one of the basins that Klemme classifies as a Class IIIC modified by a Class IV basin */ yes HIT3 no MISS3

space DIIC desc $/^{*}$ Evidence of a Class IIC Continental Crustal Collision Zone-Convergent Plate Margin Basin modified by a IV Delta depocenter basin */

noun-phrase /* IV-IIC Continental Crustal Collision Zone (Tethyan) Basin modified by a Delta Basin */

ques $I^{*}$ HAVE YOU ALREADY RUN THE IIC CONTINENTAL CRUSTAL COLLISION ZONE (TETHYAN) BASIN MODEL IN THIS CLASSIFICATION SYSTEM SO THAT YOU ARE FAIRLY CERTAIN THAT YOU HAVE A CLASS IIC BASIN */

expl $/^{*}$ I am trying to determine if you have already classified your complex basin as to being in the Class IIC 
space BACK4 desc/* Recommendation for running Class IIC basin model */

inf $/^{*}$ If you are uncertain whether your complex basin is of the Class IIC type (Continental Crustal Collision Zone-Convergent Plate Margin (Tethyan) Basin), you should go back and first run the Class IIC basin (model 4) for the basin description. Then, if your Class IIC basin has been modified further by a delta depocenter of Tertiary age, return to this basin Class IV (model 8) for final description of your basin. */

space GOOD4 desc /* Evidence of a Class IIC-IV basin */

ques ${ }^{*}$ DO YOU HAVE A MULTICYCLE TETHYAN BASIN THAT IS LOCATED IN EITHER THE NORTHERN, SOUTHERN, OR CENTRAL TETHYS AND THAT OCCURS IN THE MAJOR COLLISION ZONE BETWEEN GONDWANA AND LAURASIA EXTENDING FROM THE WESTERN END OF THE GULF OF MEXICO THROUGH THE MEDITERRANEAN AREA, THE HIMALAYAS AND INTO THE INDONESIAN ISLAND ARC AREAS, AND CONSISTS USUALLY OF AN OROGENICALLY DERIVED FOREDEEP AND FOLDBELT FORMING AN ASYMMETRICAL, IRREGULAR, TILTED BASIN, AND ALL MODIFIED BY THE OCCURRENCE OF A DELTA DEPOCENTER OF TERTIARY AGE WITHIN THE BASIN *I

expl /* I am summarizing the basic description of a Class IIC Klemme basin that is further modified by a delta depocenter of Tertiary age. If you are uncertain as to whether your complex basin is of the Class IIC type, then answer No */yes FINE2 no BACK4

space FINE2 desc $/ *$ Evidence of a Class IIC-IV basin analog */

ques ${ }^{*}$ IS YOUR BASIN ONE OF THE FOLLOWING IIC ANALOG BASINS AS CLASSIFIED BY KLEMME OR A BASIN VERY SIMILAR GEOLOGICALLY TO THESE ANALOG BASINS: PO DELTA (IICb-IV), BENGAL DELTA AND FAN (IICb-IV), MISSISSIPPIAN DELTA IN THE GULF OF MEXICO, OR POSSIBLY THE MEKONG DELTA, THE NILE DELTA OR THE MAGDALENA DELTA */

expl /* I am trying to determine if the basin you have described is one of the basins that Klemme classifies as a Class IIC modified by a Class IV basin (or a similar basin). */yes HIT4 no MISS2

space HIT4 desc $/ *$ Evidence of a Class IIC basin modified by a Class IV basin */

inf $l^{*}$ Congratulations! From the description of your basin you appear to have a Class IIC Continental Crustal Collision Zone-Convergent Plate Margin (Tethyan) Basin that has been modified further by a Class IV Delta Depocenter Basin. You are now ready to make a more detailed analysis of your basin. Good Luck! */ 
APPENDIX L.-INFERENCE NET AND LISTING FOR CLASS V-FOREARC BASINS (MODEL 9), FILE NAME FOREAC

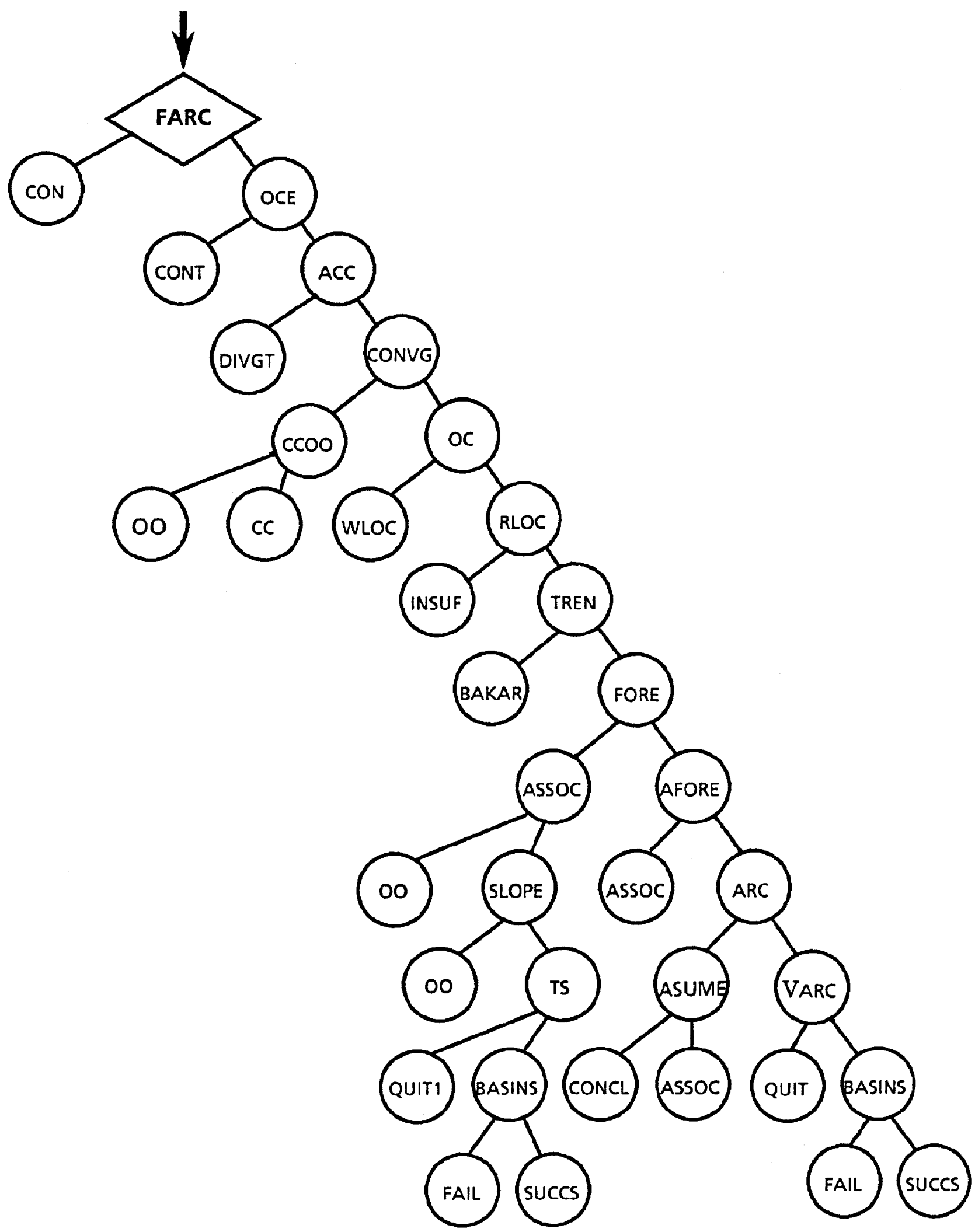

Inference net for Class V-Forearc Basins (model 9), file name FOREAC. 
model FOREAC

topspace FARC

space FARC desc $/ *$ Evidence of Oceanic Forearc Basins */

ques $/ *$ IS YOUR BASIN LOCATED ON OCEANIC CRUST (PLATES) OR LOCATED PRIMARILY ON OCEANIC CRUST, AS OPPOSED TO BEING LOCATED PRIMARILY ON CONTINENTAL CRUSTAL MARGINS */

expl $/^{*}$ I am trying to determine the location of your basin relative to the Earth's major crustal zones, that is, whether the basin is located on oceanic crust or located primarily on oceanic crust, as opposed to the basin being located completely on continental crust or primarily on continental crustal margins. */yes OCE no CON

space CON desc $/ *$ Evidence of basins located on continental crust or primarily on continental crust */

inf $/ *$ From the description of your basin you probably have some class of continental or continental margin basin and you should check the other continental basin models (models 1 through 8 ) in this world basin classification system. */

space OCE desc /* Evidence of basins located on oceanic crust or primarily on oceanic crust */

ques $l^{*}$ IS YOUR BASIN LOCATED OFFSHORE AND PRIMARILY ON AN ACCRETED ZONE OVERLYING AN OCEANIC CRUST, AS OPPOSED TO BEING LOCATED PRIMARILY ON A CONTINEN-

TAL CRUSTAL MARGIN */

expl /* I am trying to determine if you have an offshore basin that overlies oceanic crust rather than a continental margin basin that is located primarily on continental crust with some overlapping onto oceanic crust */ yes ACC no CONT

space CONT desc $/ *$ Evidence of continental margin basin models */

inf $/ *$ From the early description of your basin you probably have a basin located along a continental margin that lies primarily on continental crust, or completely on continental crust. You should check the other Klemme basin classes in this basin classification system, primarily Class IIIA, IIIB, and IIIC basins (models 5, 6, and 7), and the Class IIC and IV basins (models 4 and 8). */

space ACC desc /* Evidence of convergent margin basins */

ques $/ *$ IS YOUR BASIN LOCATED ON CONVERGENT PLATE MARGINS, AS OPPOSED TO DIVERGENT PLATE MARGINS */

expl /* I am trying to determine if your basin is located on converging plate margins as opposed to location on diverging plate margins, relative to their plate movements */yes CONVG no DIVGT

space DIVGT desc $/ *$ Evidence of divergent plate-margin basins */

inf $l^{*}$ From the description of your basin you have some form of a divergent basin. It may be any one of the following: Class IIA or IIB (models 2 and 3), or Class IIIA or IIIC (models 5 and 7), or possibly a Class IV basin (model 8). You should check these other basin models in this classification system. */

space CONVG desc /* Evidence of an oceanic basin located near a subduction zone */

ques $/ *$ IS YOUR BASIN LOCATED OFFSHORE NEAR THE MARGINS OF TWO CONVERGING PLATES (AN OCEANIC AND A CONTINENTAL PLATE), WITH SUBDUCTION OF THE OCEANIC PLATE BENEATH THE OVERRIDING CONTINENTAL PLATE, AS OPPOSED TO THE CONVERGENCE OF TWO CONTINENTAL PLATES OR TWO OCEANIC PLATES */

expl $/ *$ I am trying to determine if your basin is located at the intersection of two converging plates that consist of an oceanic plate being overridden by a continental plate, rather than two converging plates, either both oceanic or both continental in composition. */ yes $\mathrm{OC}$ no $\mathrm{CCOO}$

space $\mathrm{CCOO}$ desc $/ *$ Evidence of two converging continental plates */ 
ques $/ *$ IS YOUR BASIN LOCATED NEAR THE MARGINS OF TWO CONVERGING CONTINENTAL PLATES, AS OPPOSED TO BEING NEAR THE MARGINS OF TWO CONVERGING OCEANIC PLATES */

expl $/ *$ I am trying to determine if your basin is on the converging margins of two continental plates, as opposed to the converging margins of two oceanic plates. */ yes $\mathrm{CC}$ no $\mathrm{OO}$

space CC desc $/ *$ Evidence of a Tethyan crustal collision zone basin */

inf $/^{*}$ From the description of your basin it appears that you may have a basin located in a crustal collision zone between two continental plates. These basins are usually classified by Klemme as a Class IIC basin of the Tethyan variety. I would suggest that you check out the Class IIC (model 4) in this basin classification system. */

space $\mathrm{OO}$ desc $/ *$ Evidence of Oceanic Trench basin */

inf $/ *$ From the description of your basin it appears that you may have a basin located in a crustal collision zone between two oceanic plates. This usually involves one oceanic plate overriding another, forming a mid-ocean trench such as the Mariana, Aleutian, or Philippine trench. These features normally have little sediment fill, and the amount they do have primarily is volcanogenic and deep-water pelagic. These basins appear to have very little prospect of containing commercial hydrocarbons. */

space OC desc $/ *$ Evidence of basin location in circum-Pacific or Lesser Antilles */

ques $/ *$ IS YOUR BASIN LOCATED OFFSHORE ALONG THE PERIPHERY OF THE CIRCUMPACIFIC OR INDONESIAN ISLAND ARC OR IN THE MIDDLE AMERICA AND (OR) LESSER ANTILLES ISLAND ARC */

expl /* I am trying to determine the location of your oceanic subduction zone basin and if it is in any one of the four areas named in the above question. Answer Yes if your basin is in any one of the named areas. Answer No if your basin has a different location. */ yes RLOC no WLOC

space WLOC desc $/ *$ Evidence of a different type of convergent basin */

inf $l^{*}$ From the description of your basin you either have a Class IIC variety that may be of a Tethyan type located in a crustal collision zone area that downdips into a small ocean basin and, therefore, you should run basin model 4, OR you should rerun this basin model 9 and recheck some of your geologic information, OR run some of the other convergent basin models in this svetem, such as Class IIIB basin model 6. */

space RLOC desc /* Evidence of a trench-forearc-and-backarc basin locale */

ques $/ *$ IS YOUR BASIN LOCATED OFFSHORE ALONG ACTIVE CONVERGENT PLATE MARGINS WHERE THE OCEANIC PLATE IS BEING CONSUMED BY SUBDUCTION AND IN AN AREA USUALLY DESCRIBED AS A TRENCH-FOREARC-AND-BACKARC SITUATION */

expl /* I am trying to determine if the area of your basin can be described as a trench-forearc-backarc geologic situation where several different types of basins may be formed. */yes TREN no INSUF

space INSUF desc $/ *$ Evidence of a Tethyan basin */

inf $/^{*}$ From the description of your basin it appears that you may have a Central Tethyan basin, possibly located at the eastern end of the Tethys near the Indonesian island arc or at the western end of the Tethys near the Caribbean or Gulf of Mexico, with a description similar to a Forearc basin. I would suggest that you check Class IIC (model 4) in this basin system. */

space TREN desc $/ *$ Evidence of a Forearc area */

ques ${ }^{*}$ IS YOUR BASIN LOCATED OFFSHORE ON AN ACCRETED ZONE OVERLYING OCEANIC CRUST LANDWARD OF A TRENCH, AND (OR) SEAWARD OF EITHER A NONVOLCANIC ARC OR A VOLCANIC ARC (TRENCH-ASSOCIATED BASINS), AS OPPOSED TO BEING LOCATED ON THE CONTINENTAL CRUST AND LANDWARD BEHIND A VOLCANIC ARC (BACKARC BASIN) */

expl /* I am trying to determine if your basin is located seaward of a nonvolcanic or volcanic arc and (or) landward of an oceanic trench, as opposed to being located landward of a volcanic arc and actually overlying 
space BAKAR desc /* Evidence of a Backarc Basin */

inf $l^{*}$ From the description of your basin it appears that you have a Klemme Class IIIB basin, a Rifted Convergent Margin Basin, with oceanic crustal consumption of either a Backarc, Transform, or Median variety. Please check the Class IIIBa, IIIBb, or IIIBc descriptions in the IIIB Class (model 6) in this world basin classification system. */

space FORE desc /* Evidence of a Class V Forearc Basin */

announce $/ *$ Congratulations! It would appear so far that you have successfully described a type of Forearc basin. The following questions will aid you in further defining a Class V Forearc Basin. */

ques $/ *$ IS YOUR BASIN LOCATED BETWEEN AN OUTER HIGH, WHICH MAY BE A TERRACE, SHELF-EDGE HIGH, OR NONVOLCANIC ARC, AND A VOLCANIC ARC, AND DOES THE BASIN LIE OFFSHORE FROM THE CONTINENTAL MARGIN OVERLYING AN OCEANIC SUBDUCTION ZONE $* j$

$\operatorname{expl} /^{*} \mathrm{I}$ am trying to determine if your basin is located seaward, between the volcanic arc and the outer high, as opposed to being located seaward of the outer high and on the inner slope of an oceanic trench. */ yes AFORE no ASSOC

space AFORE desc $/ *$ Evidence of a simple Forearc Basin */

ques ${ }^{*}$ IS YOUR BASIN BUILT ON FOLDED TRENCH SEDIMENTS, ON OCEANIC CRUST, AND FORMED BY A SIMPLE SAG THAT LIES PARALLEL TO AND AT THE BASE OF THE CONTINENT AND ISLAND ARC MARGINS, AND MAY BE DEFORMED BY CONTEMPORANEOUS WRENCHING AS OPPOSED TO BEING AN INNER SLOPE TRENCH-ASSOCIATED BASIN */

expl /* I am trying to define more closely a Forearc Basin to distinguish it from an inner slope trenchassociated basin.*/yes ARC no ASSOC

space ARC desc /* Evidence of Forearc Basin sediments */

ques $/ *$ DO YOU HAVE A BASIN CONSISTING OF A SINGLE MAJOR MORPHOLOGIC CYCLE AND FILLED WITH A HIGH PERCENTAGE OF VOLCANICLASTIC SEDIMENTS, QUARTZ OR ARKOSIC SANDS, AND POSSIBLY BOTH MARINE AND NONMARINE SEDIMENTS */

expl /*I am just trying to get more geologic detail from you regarding the sediments in your Forearc Basin. */yes VARC no ASUME

space ASUME desc $/ *$ Favorable assumption relative to a more complex forearc basin */ ques ${ }^{*}$ WOULD YOU LIKE TO ASSUME THAT YOU HAVE A MORE COMPLEX FOREARC BASIN THAN THE SITUATION DESCRIBED IN THE PREVIOUS QUESTION AND THAT IT MAY LIE FURTHER SEAWARD ON THE OCEANIC CRUST $* /$

expl /* I am trying to explore in more detail the possibilities that you may have an inner slope trench basin, or even the chance that you may have an oceanic trench basin. */yes ASSOC no CONCL

space CONCL desc /* Evidence of some type of Forearc Basin or some other type of marginal basin */

inf $/ *$ From the description of your basin you have the following possibilities: (a) a Forearc basin with insufficient data to pinpoint it more closely as to a specific type, OR (b) a need to rerun this Class $\mathrm{V}$ basin model and reconsider some of your geologic answers, OR (c) the possibility that you may have some other type of continental convergent margin basin and should select one of the other basin models for a different Klemme class basin. Good Luck! */

space VARC desc /* Check for a list of analog basins as classified by Klemme as simple Class V Forearc Basins */ announce $/ *$ Congratulations! You have successfully described a simple Forearc Basin that fits the description of a Klemme Class V basin. *I 
ques $/^{*}$ WOULD YOU LIKE TO CHECK THE LIST OF WORLD BASINS THAT HAVE BEEN CLASSIFIED BY KLEMME AS CLASS V FOREARC BASINS */

expl /* I am trying to determine if your basin is in the list of world basins classified by Klemme as Class V basins, or to see if any of these basins might be an analog to your basin with a similar geology. */ yes BASINS no QUIT

space QUIT desc /* Check for list of analogs of a Forearc Basin */

inf $/ *$ Congratulations! You apparently have a Forearc Basin of the Klemme Class V classification. However, you have not checked the list of world basins that have been classified by Klemme as Class V basins. If you wish to do so, then you will need to rerun this model and answer the previous question Yes. If you are certain that you have a Class V basin, then you are ready to make a more detailed analysis of your basin. Good Luck! */

space ASSOC desc $/ *$ Evidence of a trench-associated inner slope basin $* /$

ques $/ *$ IS YOUR FOREARC BASIN LOCATED SEAWARD OF A NONVOLCANIC OUTER HIGH AND DOES IT LIE BETWEEN THIS HIGH AND AN ASSOCIATED TRENCH AS A TRENCH INNER SLOPE BASIN, AS OPPOSED TO BEING LOCATED LANDWARD OF THE NONVOLCANIC HIGH OR BEING LOCATED FAR OFFSHORE AS AN OCEANIC TRENCH */

expl /* I am trying to determine if your basin is located seaward of an outer nonvolcanic high and between that high and an oceanic trench, as opposed to being located landward of the outer nonvolcanic high, or being located far offshore as a mid-oceanic trench. */ yes SLOPE no OO

space SLOPE desc /* Favorable description for a Trench Inner Slope Basin */

ques $/ *$ HAVE THE SEDIMENTS IN YOUR TRENCH INNER SLOPE BASIN BEEN SUBJECTED TO COMPRESSIONAL THRUSTING AND FOLDING BENEATH THE TRENCH INNER SLOPE DUE TO UNDERTHRUSTING OF THE OCEANIC PLATE, AND HAVE THESE SEDIMENTS A STEADY SEAWARD OVERLAP OF TRENCH FILL */

expl $l^{*}$ I am trying to determine the nature of the trench sediments, particularly those of the inner trench slope. These sediments may be partially oceanic pelagic sediments and volcanics, as well as land-derived fine clastics. These ocean margin trenches can accumulate very thick deep-water deposits. With continued plate convergence and its attendant compression, shearing, and overthrusting, a major accretion of sediments is formed by outward building of the trench slope. */ yes TS no OO

space TS desc $/ *$ Check of analog basins for trench-associated inner slope basin */

announce $/ *$ Congratulations! From the description of your basin it appears that you have a Klemme Class V basin of the trench-associated inner slope variety. It is well to note that results from past exploration have been poor in these basins and it appears that this basin type may have very little future prospects for containing commercial hydrocarbons. */

ques $/ *$ WOULD YOU LIKE TO CHECK THE LIST OF WORLD BASINS AS CLASSIFIED BY KLEMME AS CLASS V FOREARC BASINS */

$\operatorname{expl} / *$ I am trying to determine if you have a basin that has been classified by Klemme as a Class V basin, or whether you might have a basin that is similar to one of these analog basins. */yes BASINS no QUIT1

space QUIT1 desc /* Evidence of a trench-associated inner slope Class V Forearc Basin */

inf $/^{*}$ Congratulations! You appear to have a trench-associated inner slope Klemme Class V Forearc Basin. However, you have not checked the list of world basins classified by Klemme to see if your basin is in the list. If you wish to do so, you will have to rerun this basin model and answer the previous question Yes. If you are certain that you have a Class V basin, you are ready to make a more detailed analysis of your basin. Good Luck! *

space BASINS desc /* Evidence of a Class V basin as classified by Klemme */

ques $/ *$ DO YOU HAVE ONE OF THE FOLLOWING BASINS CLASSIFIED BY KLEMME AS A CLASS

$V$ BASIN OR A SIMILAR BASIN THAT MIGHT BE AN ANALOG TO THESE BASINS: GULF OF 
ALASKA, AMLIA, AMUKTA, BELLINGHAM, GEORGIA, KODIAK, PORTLOCK, PRATT, SHUMAGIN, TOFINO, TUGIDAK, TYEE, WINONA, ANCUD, ATACAMA, ATRATO, BARBADOS, DARIEN, JIPIJAPA, LIMON-BOCA DEL TORO, LINARES, MUERTOS, NICOYA, PACIFICO, PANAMA CENTRAL, PANAMA GULF, PERU COASTAL, SAMBU, SANTIAGO, SINU-URABA, TEHUANTEPEC, ANDAMAN, BENKULU, CENTRAL VALLEY PHILIPPINES, ENSHUNADA-KUMANONADA, ISHIKARI-HIDAKA(IIIBb-V), JOBAN, KANTO, KITAKAMI, MEULABOH, MINDORO EAST AND SOUTHWEST, MIYAZAKI-HYUGA, NIAS, NICOBAR, NORTH AND SOUTH NORFOLK (IIIB-V), SAVU, SOUTH JAVA TRENCH, TOKI-TOSA, AND EAST KAMCHATKA */

expl /* I am trying to determine if your basin is one of the basins classified by Klemme as a Class V Forearc Basin, or if one of these basins might be similar to your basin as a possible analog basin, as opposed to no basin match or no geological similarity of your basin with the basins in the list. */yes SUCCS no FAIL

space FAIL desc $/ *$ Evidence uncertain for basin classification */

inf $/^{*}$ From the description of your basin it appears that you have some variety of basin classified by Klemme as a Class V Forearc Basin. However, you did not select any one of the basins classified by Klemme as a Class V basin, or as a possible analog basin. You may want to rerun this basin model and reconsider some of your answers, OR you may be missing some important information on your basin, OR you may have a different type of continental margin basin that would be described under one of the other basin models. In any case, you should either rerun this basin model and recheck your information, or you should check out some of the other basin models. Good Luck! */

space SUCCS desc $/ *$ Successful selection of a Class V basin */

inf $/^{*}$ Congratulations! You have successfully classified your basin as a Klemme Class V Forearc Basin of either the simple Forearc variety, or as a trench-associated inner slope basin, AND have picked one of the basins from Klemme's list of Class V basins as being the specific basin or as being an analog basin. You are now ready to make a more detailed analysis of your basin. Good Luck! */ 




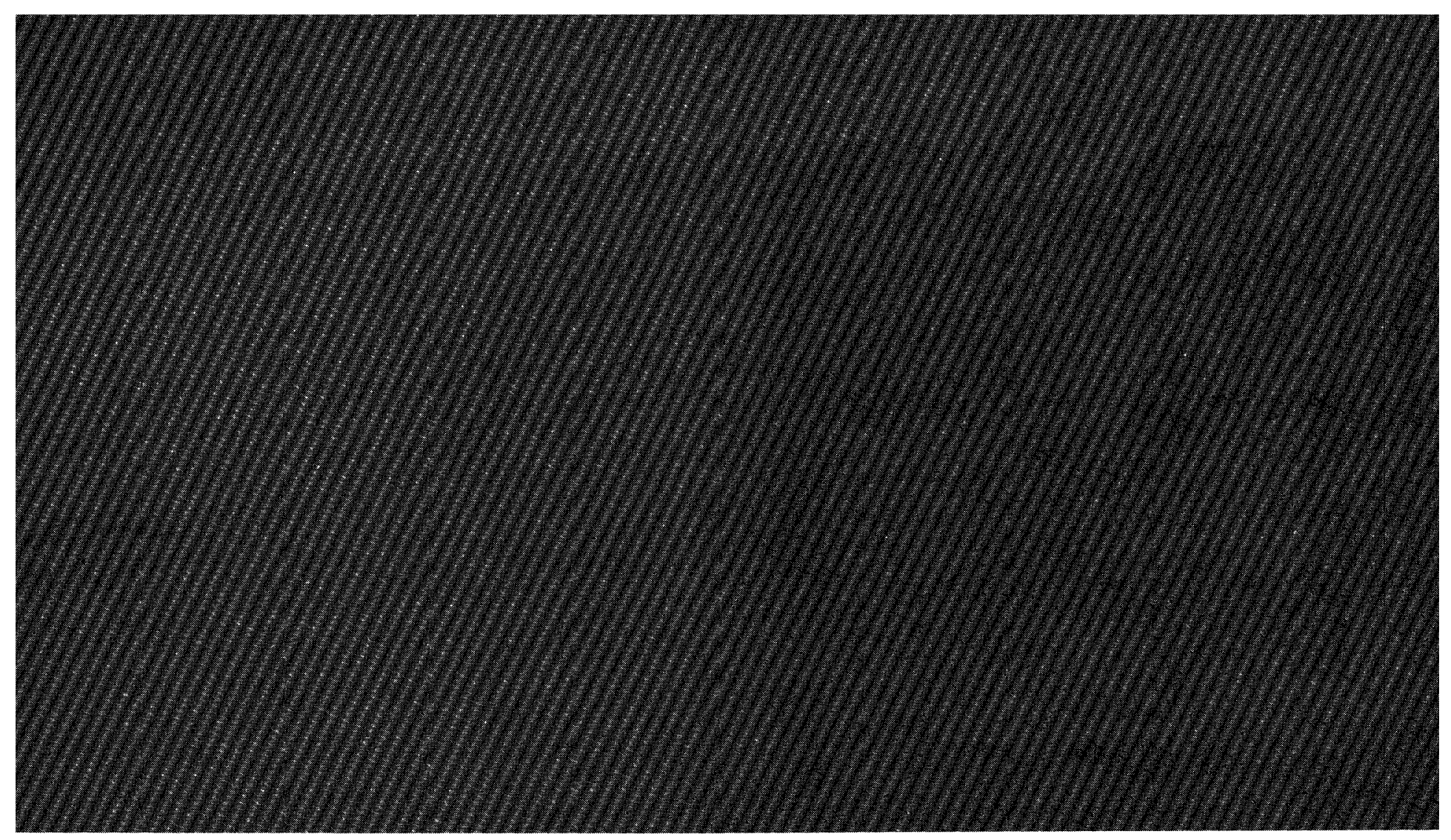

